\title{
UNIVERSITY OF IOWA STUDIES
}

\section{STUDIES IN NATURAL HISTORY}

s

\section{REPORTS ON THE CRINOIDS, OPHIU- RANS, BRACHYURA, TANIDACEA AND ISOPODA,AMPHIPODS, ఠீECHINOIDEA of the Barbados-Antigua Expedition of 1918}

Issued semi-monthly throughout the year. Entered at the post office at Iowa City, Iowa, as second class matter. Acceptance for mailing at special rates of postage provided for in section 1103, Act of October 3, 1917, authorized on July 3, 1918 . 



\title{
UNIVERSITY OF IOWA STUDIES IN NATURAL HISTORY
}

\author{
VOLUME IX \\ 1920-1921
}

UNIVERSITY OF IOWA 



\section{CON'TEN'TS}

\section{VOLÜME IX}

No. 1. Birge, E. A. and Judiy, Chancey. A limmological reconnaissance of West Okoboji.

No. 2. Stoner, DaYton. Nesting habits of the hermit thrush in northern Michigan.

No. 3. Trowbridge, A. C. The erosional history of the driftless area.

No. 4. Lindsey, A. W. The Hesperioidea of America north of Mexico.

No. 5. Clark, A. H., Rathbun, Mary .J., Buone, Pearl L., Shommaker, C. R., Clark, H. L. Reports on the Crinoids, Ophiurans, Brachyura, Tanidacea and Isopoda, Amphipods, and Echinoidea of the BarbadosAntigua expedition of 1918 . 



\section{UNIVERSITY OF IOWA STUDIES IN NATURAL HISTORY}

Professor Charles Cleveland Nutting, M. A., Editor

\section{REPORTS ON THE CRINOIDS, OPHIU- RANS, BRACHYURA, TANIDACEA AND ISOPODA,AMPHIPODS, \&ீECHINOIDEA of the Barbados-Antigua Expedition of 1918}

The Crinoids

The Ophiurans

The Brachyura

The Tanidacea and Isopoda

The Amphipods

The Echinoidea
Austin H. Clark

Austin H. Clark Mary J. Rathbun

Pearl L. Boone Clarence R. Shoemaker Hubert Lyman Clark 


\section{CONTENTS}

Crinoids ...................... 1-28

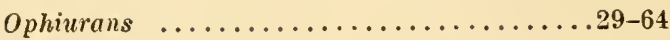

Brachyura ...................65-90

Tanidacea and Isopoda.............91-98

Amphipods ...................99-102

Echinoidea ....................103-121 


\title{
REPORT ON THE CRINOIDS
}

\author{
Collected by the Barbados-Antigua Expedition \\ from the University of Iowa in 1918 \\ Austin H. Clark \\ Curator, Division of Echinoderms, U. S. National Museum
}

\section{PREFACE}

It was most gratifying to me to be honored with a request to prepare an account of the crinoids of the State University of Iowa's Barbados-Antigua Expedition for I have myself visited Barbados four, and Antigua three times in connection with my studies on the terrestrial fauna of the West Indies, and I naturally take a keen interest in everything that concerns these islands.

Perhaps it may not be out of place here to list the titles of my previous contributions to the zoölogical literature of the Lesser Antilles. These are the following:

[A reply to Mr. P. Foster Huggins; deals witl birds]. The Sentry, Kingstown, St. Vincent, vol. 13, issue of Friday, November 20, 1903 , p. 2.

The Birds of St. Vincent. West Indian Bulletin (Barbados), vol. 5, No. 1, pp. 75-95, 1904.

Notes on the Insects of Barbados, St. Vincent, the Grenadines and Grenada. Psyche, vol. 11, pp. 114-117, December, 1904.

Description of a new Euphonia from the southern West Indies. Proc. Biol. Soc. Washington, vol. 18, pp. 19-22, February 2, 1905.

Preliminary descriptions of three new Birds from St. Vincent, West Indies. Proc. Biol. Soc. Washington, vol. 18, pp. 61-64, February $21,1905$.

The Migrations of certain Shore Birds. The Auk, vol. 22, No. 2, pp. 134-140, April, 1905.

An unrecognized Subspecies of Bellona cristatus. The Auk, vol. 22, No. 2, pp. 215-216, April, 1905.

Shore Birds eating small Fish. The Auk, vol. 22, No. 2, pp. 208-209, April, 1905. 
The Crab Hawk (Urubitinga) in the Island of St. Lucia. The Auk, rol. 22, No. 2, p. 210, April, 1905.

A supposed Specimen of the Yellow Warbler (Dendroica aestiva) from Grenada, West Indies. The Auk, rol. 22, No. 2, pp. 212-214, April, 1905.

Habits of West Indian Whitebait. American Naturalist, vol. 39, No. 461, pp. 335-337, May, 1905.

Extirpated West Indian Birds. The Auk, rol. 22, No. 3, pp. 259266, July, 1905.

The Lesser Antillean Macaws. The Auk, vol. 22, No. 3, pp. 266273, July, 1905.

The Genus Conurus in the West Indies. The Auk, rol. 22, No. 3, pp. 310-312, July, 1905.

The former status of the Flamingo and the Fish Hawk in the Lesser Antilles. The Auk, vol. 22, No. 3, pp. 318-319, July, 1905.

Birds of the southern Lesser Antilles. Proc. Boston Soc. Nat. Hist., vol. 32, No. 7, pp. 203-312, October, 1905.

The West Indian Parrots. The Auk, vol. 22, No. 4, pp. 338-344, October, 1905.

The Greater Antillean Macaws. The Auk, rol. 22, No. 4, pp. 345348 , October, 1905.

The West Indian black Forms of the Genus Cœreba. The Auk, vol. 23, No. 4, pp. 392-395, October, 1906.

The Macaw of Dominica. The Auk, vol. 25, No. 3, pp. 309-311, July, 1908.

A list of the Birds of the Island of St. Lucia. West Indian Bulletin (Barbados), vol. 21, No. 3, pp. 182-192, May, 1911.

Piccole Note su degli Onychophora. Zool. Anzeiger, vol. 42, No. 6, pp. 253-255, July 18, 1913.

Two interesting mammals from the Island of Tobago, West Indies. Ann. and Mag. Nat. Hist. [8], vol. 13, pp. 68-70, January, 1914.

The present Distribution of the Onychophora, a Group of terrestrial Invertebrates. Smithsonian Miscellaneous Collections, vol. 65, No. 1, pp. 1-25, January 4, 1915.

The present Status and Breeding Season of the Giant Toad (Bufo agua) in Barbados, St. Vincent, Trinidad and Demerara. Copeia, No. 27, February 24, 1916, pp. 13-14.

My notes on the mammals of the Lesser Antilles with references to the specimens obtained are incorporated in the following paper :

Mammals of the West Indies, by Glover M. Allen. Bull. Mus. Comp. 
Zoöl., vol. 54, No. 6, pp. 175-263, July, 1911. [On p. 201 under Leporidæ the heading Oryctolagus cuniculus should read Lepus europaeus, and Lepus europaeus in the last line on the page should read Oryctolagus cuniculus.]

\section{HISTORICAL INTRODUCTION}

The island of Barbados has long been well known as a locality for recent crinoids. The first recent stalked crinoid discovered was a specimen of Isocrimus asteria from Martinique described by Guettard under the name of "Palmier marin" in 1761; but in the very next year Ellis described another specimen of the same species from Barbados. A second individual from Barbados was described by J. S. Miller in 1821, together with one from Nevis.

The second known recent stalked crinoid was also from Martinique, and was described by d'Orbigny in 1837 under the name of Holopus rangii. It had only four rays, and was altogether such an extraordinary form that Dujardin and Hupé in 1862 suggested that possibly it was a barnacle rather than a crinoid.

In 1871 Mr. (later Sir) Rawson W. Rawson, the Governor of Barbados, sent to Dr. J. E. Gray a drawing of anotler specimen of this species which was published by the latter under the name of Holopus rawsoni. The actual specimen Gray never saw.

During his residence at Barbados Sir Rawson Rawson was so fortunate as to obtain, in addition to several specimens of Holopus rangii, examples of Isocrinus decorus and Endoxocrinus parre, and of several species of comatulids.

In 1858 d'Orbigny described from a recent breccia at Guadeloupe, which also contained a human skeleton, a fragment of a crinoid which he called Bourgueticrinus hotessieri. In 1871 the United States Coast Survey steamer "Hassler" dredged some specimens of a closely related, possibly the same, species off Sandy Bay, Barbados, which were described by Count Pourtalès in 1874 under the name of Rhizocrinus rausonii.

Comatulids were first reported from the West Indies in $\mathbf{1 8 2 5}$ by the Reverend Lansdown Guilding of St. Vincent, who mentioned them incidentally in connection with the description of a new pentacrinite which he called Encrinus milleri. In this paper 
he published the first notice of the curious brachial articulation now known as the syzygy.

Sir Rawson Rawson had secured a number of comatulids at Barbados, but the first published record for that island was Pourtalès' description of Antedon [Neocomatella] pulchella and A. [N.] alata, which appeared in 1878.

In 1912 Dr. Clemens Hartlaub's memoir on the comatulids collected by the United States Coast Survey steamer "Blake" was published, in which were listed a number of species from twenty stations off Barbados. Isolated records of individual specimens from Barbados appeared in 1912 and 1913.

\section{THE OCCURRENCE OF ISOCRINUS ASTERIA} AND OF HOLOPUS

It is an extraordinary fact that in spite of all the dredging that has been done in the Caribbean Sea and about the West India Islands only four specimens of Isocrinus asteria have been brought up, one at Montserrat by the "Blake," one at Guadeloupe by the "Blake", one off Saba by the "Investigator," and a part of a stem off Havana by the "Albatross," and only two of Holopus rangii, one, a fragment, at Montserrat, and one off Cuba, both by the "Blake." The majority of the known specimens of both these species have been taken on fishermen's lines, or by shore parties working from a small boat, or discovered on the beaches.

The apparent rarity of these species, in contrast to the other species of Isocrinus, the species of Democrinus and the species of Bythocrinus, is undoubtedly due to the fact that they inhabit shallow water, living amongst the gorgonians and corals, like the similarly rare West Indian astrophytons.

This hypothesis is supported by the occasional occurrence of Holopus rangii washed up on the windward beaches of Barbados, where it is recorded also that once after a hurricane a large number of individuals of Isocrinus of all ages and sizes were cast ashore, and by the eapture by Sir Rawson Rawson of two specimens of Holopus in $\mathbf{5}$ fathoms of water.

Speaking of the habitat of Isocrinus Sir Rawson wrote in a letter to Dr. Gray: "I have only procured one specimen of the 
Pentacrinus caput-medusa [Endoxocrinus parro], and it was the first; I am therefore more uncertain about the place where it was procured than I am about the habitat of the Pentacrinus mülleri [Isocrinus decorus]. But I believe that they are all procured on the same bank, which, instead of five or six miles from the shore, as I was first informed, cannot be more than a mile, within the hundred-fathom line."

From this it is apparent that Endoxocrinus parree and Isocrinus decorus occur in relatively shallow water at Barbados as elsewhere in the West Indies.

\section{THE RESULTS OF THE BARBADOS-ANTIGUA EXPEDITION}

While a considerable number of species have been deseribed from the Caribbean region our knowledge of the crinoids of that area is still in its infancy, and any information of any kind regarding them is therefore of interest and value.

To illustrate the paucity of the data regarding the crinoids from the very shallow water in the western Atlantic I may mention that, except for Tropiometra picta which is locally abundant from Tobago, Trinidad, and Venezuela to southern Brazil, there are only six records, one from Bahamas (Nemaster iowensis), one from the Tortugas, Florida (Nemaster iowensis, discovered by the University of Iowa's Bahamas Expedition), one from St. Thomas (Antedon dübenii), one from Dominica (Nemaster iovensis), and two from Brazil (Antedon dübenii and Nemaster sp.).

We probably already know a majority of the species inhabiting the Caribbean region; but these have been described from specimens long preserved and without notes regarding the details of their occurrence, color, or other points of interest, while in order to understand any animal we must have far more information than that included in a mere description of its differential structural characters and one or two records of its occurrence.

Considering the relative rarity of littoral and sublittoral crinoids in the Caribbean region and the difficulties attending their capture owing to the roughness of the bottom frequented by them the collection by the Expedition of representatives of this group 
at no less than twenty-five out of one hundred and one stations constitutes quite a remarkable record.

The species represented are the following:

Nemaster iowensis

Nemaster discoidea

Leptonemaster venustus
Comactinia meridionalis Analcidometra armata

Coccometra hagenii

\section{Democrinus rawsonii}

Of these seven species one, Analcidometra armata, is new to the fauna of Barbados, having previously been known only from near the Tortugas, Florida, and from off Colon. The record of Nemaster discoidea from Antigua is the first record of any crinoid from that island.

Professor Nutting's notes on the occurrence and color of the comatulids at Barbados are very interesting and instructive.

He says that "as a whole they seemed much more brilliant than the forms encountered on the 'Pentacrinus ground' off Havana and on the Pourtalès plateau by the Bahama expedition. Few marine animals are harder to secure intact than these, as the very fragile arms are almost sure to be broken in dredging, either with the dredge or tangles. We secured a number of perfect specimens by taking them from the crannies in large coral rocks brought up from time to time in the dredge. Here they had been protected and could be taken out without injury; but their colors, alas, soon vanished in preservatives. This habit of living in rocks . . . . was quite the usual thing off Barbados. We often found these crinoids far in the interior of masses of old coral rock brought up in the dredge, and we were careful to break such rock very thoroughly, as fine comatulæ were often found within a cavity in the very heart of such masses.

"It is hard to imagine the use of these brilliant colors in a habitat such as this. Of course the rocks themselves were often brilliantly colored by the assemblage of corallines, sponges and gorgonians with which they were overgrown. The predominating colors of these were red and yellow, which also characterized the comatulids as well. I find the following colorations of free crinoids mentioned in my notes: 'yellow and white; yellow and red; purple and white; black arms, with yellowish pinnules; 
rich deep vermillion, with bright yellow pinnules; lemon yellow, with black upper surface to the arms; grayish in color; violet in tinge; a crimson crinoid arm; black, with greenish yellow arms; magenta, with dark yellowish arms; one specimen very dark gray, almost black, with whitish cirri.',

\section{The Crinoid Fauna of Barbados}

Crinoids have been dredged by the steamers of the United States Coast Survey at the following stations at Barbados:

"Hassler" Station, December 30, 1871, off Sandy Bay, 100 fathoms

Neocomatella pulchella

Neocomatella alata
Comactinia echinoptera Democrinus rawsonii

"Blake" Station 272, off Barbados, 76 fathoms

Comactinia meridionalis Crinometra coronata

"Blake" Station 273, off Barbados, 103 fathoms

Neocomatella pulchella Democrinus rawsonii

"Blake" Station 274, off Barbados, 209 fathoms

Bythocrinus robustus

"Blake" Station 277, off Barbados, 106 fathoms

Neocomatella pulchella Comactinia echinoptera

Neocomatella alata

Comactinia meridionalis

Democrinus rawsonii

"Blake" Station 278, off Barbados, 69 fathoms

Comactinia meridionalis

"Blake" Station 280, off Barbados, 221 fathoms

Endoxocrinus parre

"Blake" Station 281, off Barbados, 200 fathoms

Isocrinus blakei

"Blake" Station 283, off Barbados, 237 fathoms

Endoxocrimus parre

"Blake" Station 285, off Barbados, $13-40$ fathoms

Nemaster mibiginosa. 
"Blake"' Station 286, off Barbados, 7-45 fathoms

Comactinia meridionalis

“Blake" Station 287, off Barbados, 71/2-50 fathoms

Neocomatella pulchella

"Blake" Station 290, off Barbados, 73 fathoms Neocomatella pulchella Stylometra spinifera Democrinus rawsonii

"Blake" Station 291, off Barbados, 200 fathoms Isocrinus blakei Endoxocrinus parre

“Blake" Station 292, off Barbados, 56 fathoms Stylometra spinifera

“Blake" Station 294, off Barbados, 137 fathoms Neocomatella pulchella Neocomatella alata

"Blake" Station 295, off Barbados, 180 fathoms 1socrinus blakiei Endoxocrinus parree

“Blake" Station 296, off Barbados, 84 fathoms Neocomatella pulchella Endoxocrinus parro Isocrinus decorus Democrinus rawsonii

“Blake”, Station 297, off Barbados, 123 fathoms Comactinia meridionalis Stylometra spinifera Democrinus rausonii

"Blake" Station 298, off Barbados, 120 fathoms Neocomatella pulchella Leptonemaster venustus Neocomatella alata Isocrinus decorus

"Blake', Station 299, off Barbados, 140 fathoms Neocomatella pulchella Stylometra spinifera

According to P. H. Carpenter Sir Rawson Rawson obtained at Barbados the following crinoids:

Exocyclic comatulids

Endocyclic comatulids
Isocrinus decorus Endoxocrinus parre 
There are in the British Museum the following erinoids from Barbados:

Comactinia echinoptera

Stylometra spinifera
Endoxocrinus parre

Holopus rangii

The Kiel Museum contains two crinoids from Barbados, collected in 1873 :

$$
\text { Nemaster discoidea }
$$

Comactinia meridionalis

In the Hamburg Nuseum there is the following crinoid from Barbados :

\section{Isocrinus decorus}

Thus the known erinoid fauna of Barbados in 1913 included the following seventeen species:

$\begin{array}{ll}\text { Neocomatella pulchella } & \text { Crinometra coronata } \\ \text { Neocomatella alata } & \text { Coccometra hagenii } \\ \text { Nemaster rubiginosa } & \text { Isocrinus asteria } \\ \text { Nemaster discoidea } & \text { Isocrinus decorus } \\ \text { Leptonemaster venustus } & \text { Isocrinus blatei } \\ \text { Comactinia echinoptera } & \text { Endoxocrinus parre } \\ \text { Comactinia meridionalis } & \text { Holopus rangii } \\ \text { Stylometra spinifera } & \text { Democrinus rawsonii }\end{array}$

Bythocrinus robustus

It is interesting that specimens of the following, practically half of the total number, had been brought up on fishermen's lines or captured in other ways without the assistance of elaborate dredging gear:

Nemaster discoidea

Comactinia echinoptera

Comactinia meridionalis

Stylometra spinifera
Isocrinus asteria

Isocrinus decorus

Endoxocrinus parre

Holopus rangii

Indeed, Isocrinus asteria and Holopus rangii have both been found washed up on the beaches.

\section{The West Indian Crinoid Fauna}

There are known from recent seas 576 described species of crinoids, representing 142 genera which are distributed among 28 families and subfamilies; of these, 76 species, included in 22 
genera and 6 families, are stalked, while 500 species, included in 120 genera and 22 families and subfamilies, are of the unstalked comatulid type.

In the West Indian region there occur 51 species (exclusive of two inadequately described) distributed among 30 genera and 16 families and subfamilies; of these 12 species belonging to 8 genera and three families are stalked, and 39 species belonging to 22 genera and 12 families and subfamilies are comatulids.

It will be remembered that Dr. P. H. Carpenter in 1881, after a cursory examination of the "Blake" comatulids estimated the number of West Indian species as slightly less than 55 .

The families and subfamilies represented in the West Indian region are
Capillasterinæ
Comactiniinæ
Colobometridæ
Tropiometridæ
Thalassometridæ
Charitometridæ
Antedoninæ
Thysanometrinæ

Of the genera the following 16 are confined to the West Indian region, though all of these, excepting Holopus, are closely related to Indo-Pacific genera

\begin{tabular}{|c|c|}
\hline Nemaster & HORAEOMETRA \\
\hline LEPTONEMASTER & Crinometra \\
\hline Comatonia & HyвомETRA \\
\hline Comatilia & COCCOMETRA \\
\hline Microcomatula & ZENOMETRA \\
\hline Comactinia & HYPALOMETRA \\
\hline ANALCIDOMETRA & HoLopus \\
\hline Strlometra & ISOCRINUS \\
\hline
\end{tabular}

The following 3 genera occur also in the eastern Atlantic, but not in the Indo-Pacific region

Neocomatella ANTEDON

RhIZOCRINUS 
The following 11 genera occur in the Indo-Pacific region as well as in the West Indies

TROPIOMETRA

Crotalometra

ADELOMETRA

TRICHOMETRA

Pentametrocrinus
Atelecrinus

ENDOXOCRINUS

BATHYCRINUS

Monachocrinus

DEMOCRINUS

\section{BYTHOCRINUS}

This shows graphically the isolation of the crinoid fauna of the Caribbean area.

The Geological Significance of the West Indian Crinoid Fauna

Of the six fossil groups which are represented by recent species, the Zygometridæ, Pentacrinidæ, Holopodidæ, Apiocrinidæ, Bourgueticrinidæ and Plicatocrinidæ, three, the Pentacrinidæ, Holopodidæ and Bourgueticrinidæ, occur in the West Indian region, and the Plicatocrinidæ, inhabiting the abysses and known from off west Africa, probably will eventually be found there.

The genera occurring in the West Indies which include both recent and fossil species are the following

\section{Family Pentacrinidæ}

Isocrinus

Range of the recent species.-West Indies.

Horizons.-Trias and Jurassic; Europe and North America.

Family Holopodidæ

Holopus

Range of the recent species.-West Indies.

Horizon.-Tertiary; Italy.

Rhizocrinus

Family Bourgueticrinidæ

Range of the recent species.-West Indies to Massachusetts, and northwestern Europe.

Horizons.-Cretaceous, New Jersey; Eocene, Europe.

Democrinus

Range of the recent species.-Tropical Atlantic and East Indies.

Horizon.-Recent; Guadeloupe.

As in all the rest of the world there are only two genera, 
Catoptometra and Eudiocrinus, both belonging to the Zygometridæ and both ranging from the Malayan region to southern Japan, which are definitely known to include both recent and fossil species, it would seem that the Caribbean region has a closer affinity with the past faunas than has any other area.

The relative antiquity of the West Indian crinoid fauna seems to be attested by the following facts:

Of the 8 genera of stalked erinoids represented 4, or one-half, occur also as fossils; in the Indo-Pacific region out of 19 stalked genera only 1 occurs as a fossil.*

Of the 30 genera of comatulids 23 , or $77 \%$, include only five or ten armed species. The Comasterinae, Himerometridae, Stephanometridae and Mariametridae, including only multibrachiate species, are not represented; the ZyGOMETRIDAE, many species of which are conspicuous for the great number of arms, is also unrepresented.

Of these 30 comatulid genera 23 , or $77 \%$, are monotypic, or are represented by a single species.

\section{KEY TO THE GENERA OF CRINOIDS REPRESENTED IN THE CARIBBEAN SEA AND ADJACENT WATERS}

a1 No stem; the center of the dorsal side of the animal is occupied by a single more or less thick plate or knob bearing jointed appendages by means of which the animal attaches itself.

$b^{1}$ five very long and slender arms

Pentametrocrinus

$b^{2}$ ten or more arms

$\mathrm{c}^{1}$ one or more of the proximal pinnules bears in its terminal portion a comb-like structure formed by the production of the distal outer side of each of the segments in the form of a long thin triangular process

di more than ten arms

$\mathrm{e}^{1}$ all of the division series are composed of two ossicles; the lowest pinnule is on the second brachial following the last axillary

Neocomatella

$e^{2}$ first division series of two ossicles, the second of four of

${ }^{\star}$ Cf. The Ontogeny of a Genus, American Naturalist, vol, 45, No. 534, June, 1911, pp. 372-374; The Comparative Age of the Recent Crinoid Faunas, American Journal of Science [4], vol. 32 (whole No. 182), No. 188, August, 1911, pp. 127.132; Das relative Alter der rezenten Seelilienfaunen, Naturwiss. Rundschau, JG. 27, No. 15, April 11, 1912, pp. 191.192; On the Deep Sea and Comparable Faunas, Intern. Revue der ges. Hydrobiol. und Hydrogr., vol. 6, 1913, Heft 1, pp. 17.30, Heft 2/3, pp. 133-146. 
which the two outer are united by syzygy, the following of three of which the two outer are united by syzygy; sometimes the division series are very irregular; the first pinnule following the outermost axillaries is on the first brachial

Nemaster

$d^{2}$ ten arms

$e^{1}$ cirri short and stou with the dorsal profile smooth, there being no processes on the distal ends of the segments; the segments of the middle pinnules are slort and broad, with the distal corners more or less produced

Comactinia

$\mathrm{e}^{2}$ cirri longer and more slender, the outer segments bearing more or less prominent processes on the dorsal side of the distal ends

f1 the three pairs of pinnules following the first pair on each arm are absent

\section{Comatilia}

f2 all of the pinnules are present

gl first and second segments of the proximal pinnules with a very high and prominent carinate process of which the onter edge, at least on the second segment, is parallel with the longitudinal axis of the pinnule

Leptonemaster

g2 there are no carinate processes on the basal seg. ments of the proximal pinnules

h1 cirri slender, but not excessively so; terminal comb arising at about, or even within, the proximal third of the pinnules of the first pair, composed of exceptionally large rounded teeth which usually much exceed in height the lateral diameter of the segments which bear them, and frequently absent; 4th-7th brachials with prominent spinous median knobs or keels; usually one or more of the earlier segments of $P_{1}$ is twice as long as broad, or even longer; size moderate

Comatonia

h2 cirri excessively slender and threadlike, the enormously elongated segments with greatly swollen articulations; the penultimate segment, which is much shorter than those preceding, is twice as long as broad; terminal 
comb confined to the tip of the proximal pinnules, and of the usual type; no carination of the earlier brachials; none of the segments of $P_{1}$ elongated

Microcomatula

$\mathrm{c}^{2}$ no comb-like structures on the proximal pinnules

d1 there are no deposits in the ventral perisome of the pinnules visible to the naked eye

el each cirrus socket is bordered proximally and laterally by a prominent raised rim; a narrow eirelet of basals separates the centrodorsal from the radials; centrodorsal conical, the cirrus sockets arranged in ten equidistant columns; first syzygial pair and following brachials very obliquely wedge-shaped or triangular

Atelecrinus

$e^{2}$ no raised rim about the proximal and lateral portions of the eirrus sockets; no basals; first syzygial pair oblong; following brachials oblong or slightly wedge-shaped, later becoming triangular, or at least more obliquely wedge-shaped

fi centrodorsal elongate, conical or columnar, with the eirrus sockets arranged in 10 definite columns

g1 the ten columns of eirrus sockets are closely crowded on a conical centrodorsal; size small; color yellow

Adelometra

g2 the ten columns of cirrus sockets are segregated in five radial pairs separated by high interradial ridges; centrodorsal columnar; size medium or large; color red or purple

Zenometra

f2 cirrus sockets closely crowded, and without definite arrangement

g1 proximal pinnules absent; lowest pinnule on the fifth brachial

Hypalometra

g2 proximal pinnules present; the second and following brachials bear pinnules

h1 first pinnule extraordinarily flexible, composed of more than 30 segments which are about as long as broad with their corners cut away, appearing like a string of minute beads; second and following pinnules of the 
same length, but composed of about half as many much longer segments, and much less flexible

Coccometra

h2 most or all of the segments of the first pinnule longer than broad

i1 proximal pinnules all of the same character; first pinnule shorter than the second, which is shorter than the third

$j^{1}$ each brachial has the midline of the dorsal surface raised into a high prominent keel; the division series and first two brachials are very broad, in close lateral contact with their neighbors, and only slightly convex dorsally; the genital pinnules are very long, the longest pinnules on the arm; the centrodorsal is very large, columnar or broad truncated conical; the cirri are short and stout, without dorsal processes; the general habitus is stout

Tropiometra

$j^{2}$ the dorsal surface of the brachials is unmodified, but their distal edges are produced in a frill of long spines; the division series and lower brachials are narrow and well rounded dorsally; the genital pinnules are shorter than the proximal or distal pinnules, which are of the same length; all the pinnules are very slender and stiff, especially the lower, which are thornlike, the component segments with numerous long spines on their distal ends

Hybometra

i2 first pinnule markedly longer than the second and following

$j^{1}$ first pinnule rery stout, and so large at the base as to give the second brachial the appearance of an axil. lary; edges of the elements of the division series armed with coarse 
short spines; eirri short and stout, with short subequal segments most of which bear high dorsal spines, the more proximal with a transversely elongate chisel-like edge

Analcidometra

$j^{2}$ first pinnule much elongated, but not especially stout; no true dorsal spines on the cirrus segments

$\mathrm{k}^{1}$ centrodorsal rounded conical, almost entirely covered with from 40 to 60 cirrus sockets; cirri long, rather slender, composed of from 25 to 30 segments; proximal brachials with the distal edge abruptly everted and conspicuously spinous; first pinnule more slender than those following; division series and lower brachials in close lateral apposition and flattened against their neighbors

Trichometra

$\mathrm{k}^{2}$ centrodorsal very low, flattened hemispherical, with less than 35 cirrus sockets; eirri short, rather stout, with not more than $15 \mathrm{seg}$ ments; no eversion of the distal borders of the earlier brachials; first pinnule stouter than those succeeding; division series and arm bases narrow and widely separated; a cluster of perisomic interradial plates in each interradial angle

Antedon

$d^{2}$ the ambulacral grooves on the pinnules and arms are bordered by two rows of minute plates easily seen in dried specimens of which those of the inner row can be closed down over them

e1 cirri short and stout, strongly curved, with not more than 20 segments none of which bear dorsal spines; centrodorsal very broad, more or less columnar or broad truncated conical, the cirrus sockets elosely erowded and irregularly arranged; first two pinnules similar, slender, 
composed of numerous short segments; 20-30 arms; proximal portion of animal usually highly ornamented with spines or tubereles, though sometimes plain

Crinometra

$\mathrm{e}^{2}$ eirri long, with more than 30 segments of which the outer bear prominent dorsal spines; centrodorsal rather small, more or less conical, the cirrus sockets arranged in ten columns; first pinnule longer and stouter than the following

f1 the segments in the basal half of the genital pinnules are much broadened, forming a roof over the gonads; 10 arms

Horaeometra

$f^{2}$ the segments of the genital pinnules are not expanded; usually between 20 and 30 arms

g1 very spinous; the edges of the elements of the division series and lower brachials are armed with long spines, and each of the middle and outer brachials bears a single long curved laterally compressed spine which orerlaps the base of the brachial succeding; division series and arm bases narrow, strong convex dorsally and more or less separated

Stylometra

g2 smooth; the edges of the elements of the division series and brachials are unmodified; division series and arm bases broad and in close lateral apposition

Crotalometra

$a^{2}$ A stem is present

b1 the short thick stem or stalk consists of a single unjointed element by which the animal is solidly attached to corals or other hard objects; the arms are very short and stout, six of them being considerably larger than the other four

\section{Holopus}

b2 the stem is long and many jointed; its distal end is never attached bearing five articulated processes or eirri; the stem ends abruptly, exposing the distal face of one of the columnals, which is usually more or less worn; size large

$d^{1}$ all of the division series are of two elements

Endoxocrinus

d2 the first division series is of two elements, the following always of more than two, the number increasing distally 
$e^{2}$ there are no modified columnals, and no cirri; at the end of the stem there is a cluster of roots, or radicular cirri, which may extend upward over a number of columnals

$d 1$ the third, sixth and ninth brachials (the fifth, eighth and eleventh ossicles beyond the radials) have a muscular articulation at either end; the basals are fused into a solid ring which is broader than long, cylindrical or truncated conical

Bathycrinus

d2 all the ossicles following the radials are united in pairs by non-muscular articulations; that is, muscular and non-muscular articulations regularly alternate throughout the arm; the basals are separated, or fused into a solid ring which is truncated conical, longer than broad

$\mathrm{e}^{1}$ ten arms (trelve arms in six-rayed species)

Monachocrinus

$e^{2}$ fire arms

f1 no sutures visible between the basals, which are fused into a solid conical ossicle; four to seven rays

Rhizocrinus

$f^{2}$ basals always separated by distinet sutures; always five rays

g1 stem relatively slender, the longest columnals at least twice as long as broad; calyx more or less conical

Bythocrinus

g2 stem stout, the longest columnals rarely so much as twice as long as broad, usually only slightly longer than broad; calyx almost or quite cylin. drical

Democrinus

\section{THE PLANT-LIKE INTERRELATIONSHIPS OF THE CARIBBEAN CRINOIDS}

Some years ago I stated that the study of the fixed and sedentary marine animals was often rendered exceptionally difficult through the more or less complete assumption of that type of variation which we find among the plants. Individuals of many species of plants vary very widely according to the dampness or dryness, richness or barrenness, and brightness or darkness of the locality inhabited, while in other types which will grow only within a relatively small range of conditions the variation is slight. 
The same thing is true in the fixed and sedentary marine animals, and is well illustrated by the Caribbean erinoids.

The thermal and actinic range of the stalked species is small, as they are for the most part inhabitants of deep water where conditions are practically uniform; their range of variation is therefore slight and there is little difficulty in delimiting their species.

But many, if not most, of the unstalked species in the Caribbean Sea have an unusually great bathymetrical range, their representatives in the littoral and sublittoral zones living under a great variety of conditions varying in temperature and illumination, and therefore also in the quality and quantity of the food. From this circumstance it comes about that each of the more abundant types occurs in a number of more or less distinct varieties which, intergrading in every conceivable way, are quite plant-like in their interrelationships, and which appear to be proportionate in number to the thermal and actinic range of the species.

Thus the interrelationships of the forms in the genus ComacTINIA-Hartlaub recognizes fifteen varieties of Comactinia echinoptera-and in the genus CrINOMETRA, with fifteen nominal species, recall the interrelationships of the more difficult sections of such plant genera as Cratagus, Rubus or Rosa, and those of the forms in the genus NEMASTER the interrelationslips of our local species of CirCæA.

The comatulids differ from all the other fixed and sedentary animals in being reduced to practically nothing but a food collecting apparatus, the organs not concerned, as are the arms and pinnules, in the collection of food being reduced to an absolute minimum. In the plants the species of Rafflesiaceæ are for the most part reduced to a flower only, without leaves, stem or true root, and it is interesting to note that the range in size of the species of Rafflesiacer and of the comatulids is the same, from less than an inch in diameter to about three feet (Rafflesia arnoldi and Heliometra maxima).

In the crinoids the excretion of waste products is for the most part effected by the formation of small globules (saceuli) chiefly along the ambulacral grooves which are superficially quite similar to the "glands" dotting the leaves in the Hypericaceæ and 
other plants. As a rule in the crinoids, as in many, if not most, other sedentary and fixed types, the pigment is more or less distributed throughout the entire animal (it may even be chiefly or entirely internal in some of the Polyzoa) as in most of the plants used for dyeing purposes, and is not chiefly or exclusively superficial as in most active animals. When it is recalled that the variations in the symmetry of flowers are duplicated with great exactness in the zoöids of the fixed animal types and in the crinoids, the odorous features of the Menthaceæ, most Solanaceæ, ete., are equally characteristic of sponges, the acrid juice of the Brassicaceæ is duplicated in most cœlenterates (small millepores are called "sea ginger" in Barbados), the pleasant odor of many plants is equally a feature of Flustra and other marine animals, etc., ete., the comparison between the fixed and sedentary animals and the plants is seen to be quite justified.

\section{Annotated List of the Species Obtained}

\section{Family Comasteridæ Subfamily Capillasterinæ \\ Nemaster iowensis (Springer)}

Actinometra iowensis 1902. SPRINGER, American Geologist, vol. 30, p. 98 (Florida reefs, 3 feet).-1903. Springer, Bull. Lab.

Nat. Hist. State Univ. Iowa, vol. 5, No. 3, pp. 217-221, plate 1.

Nemaster iowensis 1909. A. H. ClaRK, Vid. Medd. fra den naturhist. Foren. i Köbenhavn, 1909, p. 118.

Station 53:

Arms only; "arms black, pinnules lemon yellow at tips, shading into black."

Station 97:

Arms only.

Station 98:

Arms only.

Station 99:

Arms only.

Station 100:

Arms only. 
Barbados; Engineers' Pier, in 25 feet of water.

One specimen; the centrodorsal is very thin, discoidal, the flat dorsal pole $5 \mathrm{~mm}$. in diameter, slightly sunken in a circular area $2 \mathrm{~mm}$. in diameter in the center.

The cirri, which are arranged in a single very irregular marginal row, are XXII, 13-15, $13 \mathrm{~mm}$. or $14 \mathrm{~mm}$. long.

The 43 arms are about $90 \mathrm{~mm}$. long.

The color in life was "sulphur yellow."

Barbados.

Arms only ; "nearly black."

Nemaster discoidea (P. H. Carpenter)

Actinometra discoidea 1883. von Graff, Bull. Mus. Comp.

Zoöl., vol: 11, No. 7, p. 127 (nomen nudum; myzostomes).1884. voN GraFF, "Challenger" Reports, vol. 10, Zoölogy, part 27, p. 14 (nomen nudum; myzostomes).-1888. P. H. CarPenter, "Challenger"' Reports, vol. 26, Zoölogy, pp. 58, 316, 317, 368, 382 (Caribbean Islands, 88-118 fathoms).

Actinometra echinoptera var. discoidea 1912. Hartlub, Mem. Mus. Comp. Zoöl., vol. 27, No. 4, p. 463, pl. 17, figs. 7, 9, 15 (fig. 14, also given as this species, is probably iowensis).

Nemaster insolitus 1917. A. H. Clark, Proc. Biol. Soc. Washington, vol. 30, p. 65 ("Albatross" Station 2146, Caribbean Sea, 34 fathoms).

Station 50 :

Arms only.

Station 51:

One magnificent specimen; the centrodorsal is thin, discoidal, the flat dorsal pole $5 \mathrm{~mm}$. in diameter with a shallow central depression; the cirri are XXIV, 13, from $12 \mathrm{~mm}$. to $14 \mathrm{~mm}$. long; the twenty slender arms are about $150 \mathrm{~mm}$. long; all of the IIBr series are $4(3+4)$.

Station 70 :

Arm fragments.

Station 79 :

Arms only.

Station 85:

Part of an arm. 
Station 92:

Arms only.

Barbados.

One small specimen with 15 arms $45 \mathrm{~mm}$. long. The color in life was "very dark gray, pinnules and cirri whitish, the former banded with darker."

Detached arms, presumably from another station. The color in life was "black, with yellow pinnules."

Station 101:

One much broken specimen with 19 arms.

\section{Leptonemaster venustus A. H. Clark}

Leptonemaster venustus 1909. A. H. Clark, Proc. U. S. Nat. Mus., vol. 36, p. 499 ("Grampus" Station 5104).

Station 3 :

One small specimen; this had "a greenish tinge when fresh." Station 7 :

One small specimen; in life this was "pale yellow."

Station 11:

Twenty specimens, with arms from $20 \mathrm{~mm}$. to $50 \mathrm{~mm}$. in length; in life these were "yellow."

Station 13:

One small specimen.

Station 18:

One specimen.

Station 46 :

One specimen with arms about $65 \mathrm{~mm}$. long. The color in life is described as follows: "Arms barred with eadmium yellow; the base of each arm is of this color up to the main division, and for an eighth of an inch or more distal to this point; beyond this for a quarter of an inch, more or less, the usual white color prevails, then a yellow bar for three-sixteenths of an inch, again a white bar for about the same distance; beyond this the white prevails, the yellow bars being irregularly spaced and one-sixteenth of an inch or less in width; there are from five to seven bars, as a rule, on each arm; the pinnules over each bar tend to be yellowish; the tips of the arms are also yellowish; the cirri are a paler yellow." 


\section{Station 56:}

One specimen with arms about $30 \mathrm{~mm}$. long.

Station 59:

One specimen with arms $50 \mathrm{~mm}$. long. The color in life was "yellow."

\section{Station 67:}

Five specimens with arms up to $65 \mathrm{~mm}$. in length. The color in life was "brownish."

Station 78:

One small specimen.

\section{Subfamily Comactiniinæ}

Comactinia meridionalis (Agassiz and Agassiz)

Alecto meridionalis 1865. AGassiz and AGassiz, Seaside Studies. p. 121, figs. 153, 154 ("A. Agassiz, MS. ;" coast of South Caro lina).

Comactinia meridionalis 1909. A. H. Clark, Vid. Med. fra dę naturhist. Forening i Köbenhavn, 1909, p. 150.

Station 9 :

Arms only. In life these were either "light yellow," or "body" of arm light yellow, the pinnules deep carmine, tipped with yellow in most eases."

Station 11:

Four specimens, with the arms about $60 \mathrm{~mm}$. long. In life these had the arms "dark carmine, the pinnules orange with red and yellow spots and tipped with yellow;" or the arms were "bright purple, the pinnules more so."

Station 14:

One small specimen, with the "base of the pinnules strongly purple."

Station 51:

One young specimen with the arms $40 \mathrm{~mm}$. long.

Station 67:

Five specimens with very slender arms up to about $70 \mathrm{~mm}$. in length. In life one was "a rich earmine;" another was "rich carmine with yellow spots, the pinnules orange yellow."

Station 78:

Two specimens, the larger with the longest arms about $70 \mathrm{~mm}$ long. 
Station 85:

One specimen with arms about $70 \mathrm{~mm}$. long.

Station 96 :

Four specimens, the largest with the anterior arms $85 \mathrm{~mm}$. and the posterior $47 \mathrm{~mm}$. in length, closely resembling those collected by the "Corwin" off French Reef. In life one was "dark yellow;" the others had the "arms dark rose pink, the cirri pale yellow, the pinnules pale yellow, banded with burnt sienna.",

Barbados.

One specimen, which had the "arms deep mauve, and the pinnules very pale straw yellow banded with grayish purple."

\section{Family Colobometridæ}

\section{Analcidometra armata (Pourtalès)}

Antedon armata 1869. Pourtales, Bull. Mus. Comp. Zoöl., vol.

1, No. 11, p. 356 (west of the Tortugas, in 35 fathoms).

Oligometra caribbea 1908. A. H. Clark, Proc. U. S. Nat. Mus., vol. 34, p. 238 (off Colon, in 34 fathoms).

Station 11:

One very small specimen with arms $15 \mathrm{~mm}$. long.

Family Antedonidæ Subfamily Thysanometrinæe

Coccometra hagenii (Pourtalès)

Comatula (Alecto) hagenii 1868. Pourtales, Bull. Mus. Comp. Zoöl., vol. 1, No. 6, p. 111 (of Sand Key, Florida, in 100 fathoms).

Coccometra hagenii 1908. A. H. Clark, Proc. Biol. Soc. Washington, vol. 21, p. 129.

Station 15:

Four small and young specimens; the segments of $P_{1}$ are much longer than usual, probably owing to their small size.

\section{Family Bourgueticrinidæ}

Democrinus rawsonii (Pourtalès)

Rhizocrinus rawsonii 1874. Pourtales, Ill. Cat. Mus. Comp. Zoöl., vol. 4, No. 8, p. 27. 
Station 7 :

One extraordinarily well preserved specimen, agreeing in all details with Pourtalès' types, which were also from Barbados.

The total length is $178.7 \mathrm{~mm}$; the arms are $19 \mathrm{~mm}$. long, the calyx (including the radials) $4.7 \mathrm{~mm}$. long, and the stem, which is composed of 58 columnals plus a portion of the root, is $\mathbf{1 5 5}$ $\mathrm{mm}$. long.

\section{LIST OF THE STATIONS, WITH THE SPECIES REPRESENTED AT EACH}

Station 3: Leptonemaster venustus

Station 7: Leptonemaster venustus Democrinus rawsonii

Station 9: Comactinia meridionalis (arms)

Station 11: Leptonemaster venustus Comactinia meridionalis Analcidometra armata

Station 13: Leptonemaster venustus

Station 14: Comactinia meridionalis

Station 15: Coccometra hagenii

Station 18: Leptonemaster venustus

Station 46: Leptonemaster venustus

Station 50: Nemaster discoidea (arms)

Station 51: Nemaster discoidea Comactinia meridionalis

Station 53: Nemaster iowensis (arms)

Station 56: Leptonemaster venustus

Station 59: Leptonemaster venustus

Station 67: Leptonemaster venustus Comactinia meridionalis

Station 78: Leptonemaster venustus Comactinia meridionalis

Station 79: Nemaster discoidea (arms)

Station 85: Comactinia meridionalis

Station 92: Nemaster discoidea (arms)

Station 96: Comactinia meridionalis

Station 97: Nemaster iowensis (arms)

Station 98: Nemaster iowensis (arms) 
Station 99: Nemaster iowensis (arms)

Barbados; Engineers' Pier, 25 feet: Nemaster iowensis

Barbados: Nemaster iowensis (arms)

Nemaster discoidea

Comactinia meridionalis

Station 101: Nemaster discoidea 


\title{
REPORT ON THE OPHIURANS
}

\author{
Collected by the Barbados-Antigua Expedition from \\ the University of Iowa in 1918 \\ Austin H. Clark
}

Curator, Dirision of Echinoderms, U. S. National Aruseum

\section{PREFACE}

By a fortunate combination of circumstances it happened that just before and during the early dredging operations of the U.S. Coast Survey between 1867 and 1879 (by the steamers "Corwin," "Hassler" and "Blake"), which were the first intensive deep sea investigations ever undertaken, interest in the ophiurans had reached a pitch of intensity quite comparable to that of the revival of the past ten years centering in the Indo-Pacific and Antaretic, and new material was studied and described as rapidly as it was obtained. The two authors of those days chiefly interested in the West Indian ophiurans were Theodore Lyman of Harvard, who studied the ophiurans collected by the ships of the Coast Survey, and later those of the "Challenger," and Christian F. Lütken of Copenhagen to whom were sent a large number of specimens from the Danish West Indies, mostly from St. Thomas, collected by A. H. Riise. As many of Riise's specimens were later also sent to Lyman, the latter was enabled to study authentic examples of many of Lütken's species from the original locality.

The completeness of the early collections and the thoroughness and accuracy with which the early authors worked are attested by Professor Kœhler's report upon the ophiurans secured by the "Albatross" in the West Indies (1914) and by Dr. Hubert Lyman Clark's memoir on the ophiurans of Porto Rico (1902) and catalogue of known ophiurans (1915) in which a negligible number of new Caribbean types are described, and almost none of the earlier species placed in synonymy.

*Published with the permission of the Secretary of the Smithsonian Institution. 
Within the last few years the study of the ophiurans has taken on a renewed impetus, and a number of large and important memoirs have appeared. A rather unusual feature of this activity has been that all of the authors concerned have worked in perfect harmony and without a trace of other than the most friendly coöperation, with the result that, instead of a mass of new and conflicting ideas and testily debated new genera and species we have before us today an entirely new classification of these animals in its perfected form only two years old yet accepted by all the authorities on the subject, and an increase of something like $300 \%$ in the number of known species, over 400 having been described by a single author, very few of which it has been found necessary to place in the synonymy of older forms.

To the energy and activity of Professor René Kœhler of Lyons we are indebted for the greatest increase in the number of known types, and to Professor Hikoshichiro Matsumoto of Sendai for our new classification; to Dr. Hubert Lyman Clark of Harvard we are indebted not only for an important increase in the number of known genera and species, second only to that which we owe to Professor Kœhler, but also for a magnificent memoir in which all of the recently described new species are included, assembled under Matsumoto's revised classification.

The classification here adopted follows that employed in Dr. Clark's memoir except that, with Professors Kœhler and Verrill, I recognize the family Ophiomycetidæ, the genera of which are placed by Matsumoto and by H. L. Clark in the Ophiacanthidæ.

The memoirs which should be consulted in connection with the present paper are the following:

Report on the Ophiuroidea Collected by the Bahama ExpeDition in 1893. Addison E. Verrill. Bulletin from the Laboratories of the State University of Iowa, vol. 5, No. 1 (Bulletin of the University of Iowa, N. S., vol. 1, No. 6), September, 1899, pp. 1-86, plates 1-8.

A Contribution to the Study of Ophiurans of the U. S. National Museum. René Kœhler. Bulletin 84, U. S. National Museum, 1914, pp. i-vii, 1-173, plates 1-18. 
a New Classification of the Ophiuroidea. Hikoshichiro Matsumoto. Proceedings of the Academy of Natural Sciences, Philadelphia, 1915 (April 12, 1915), pp. 43-92.

Catalogue of Recent Ophiurans: based upon the collection of the Museum of Comparative Zoölogy. Hubert Lyman Clark. Memoirs of the Museum of Comparative Zoölogy, vol. 25, No. 4, December, 1915, pp. 165-376, plates 1-20.

A Monograph of Japanese Ophiuroidea, arranged according to a new Classification. Hikoshichiro Matsumoto. Journal of the College of Science, Imperial University of Tokyo, vol. 38, Art. 2, March 31, 1917, pp. 1-408, plates 1-7.

OpHIUREs [collected by Kükenthal and Hartmeyer in the West Indies, a number at Barbados]. René Kœhler. Zoölogischer Jahrbuch, Supplement 11, Heft 3, 1913, pp. 351-380, plates $20,21$.

\section{THE CARIBBEAN ECHINODERM FAUNA}

On the basis of the available data it is difficult to make any statements of value regarding the subdivisions of the echinoderm fauna of the American side of the tropical Atlantic. There is a certain homogeneity about it which suggests that it should be regarded as a single faunal unit locally modified, as a result of diverse ecological conditions, by the partial or complete elimination of certain types which results in local changes in the faunal balance; that is to say, the faunal characteristies of any given region are more closely dependent upon the size and character of the adjacent land mass (features determining the amount and kind of food) than they are upon fundamental faunal considerations.

The Brazilian section of this fauna includes several characteristic types not known elsewhere in the region. Perhaps the most striking of these is Paracentrotus gaimardi, which also occurs in west Africa. This species appears to be rare and local and it is not by any means certain that it does not occur in the next section.

The fauna of the continental shores of the Caribbean region, with Trinidad and Tobago, seems, so far as we can tell, to be 
essentially similar to the Brazilian, minus certain types and plus a few others. The most conspicuous of the latter is the littoral Thyraster serpentarius, but this is known only from Vera Cruz and from off Tampa Bay, Florida (Cat. No. 36995 U. S. National Museum).

The third division, which appears to be merely the preceding minus a number of its characteristic types and plus a few which possibly are not in reality confined to it, includes the Antillean Islands north of Tobago and the Atlantic coast of North America to Carolina, some of the species even reaching Cape Cod. This division is richest in species in the Greater Antilles and southern Florida, and poorest in the southern Lesser Antilles, especially on the oceanic island of Barbados.

\section{THE OPHIURANS COLLECTED BY THE EXPEDITION}

The expedition brought back representatives of forty-three species of ophiurans; of these 26 were found at Barbados only, 14 were found both at Barbados and at Antigua, and 3 were found only at Antigua.

Of the 40 species collected at Barbados the following 11 were there found for the first time:

Ophiomyxa flaccida

Astrophytum muricatum

Ophioplus tuberculosus

Amphiura diducta

Amphipholis limbata
Amphiodia planispina

Ophiactis savignyi

Ophiothrix lineata

Ophiothrix pallida

Ophiomusium sculptum

Ophiolepis elegans

The 17 species collected at Antigua constitute new records; they were:
Ophiomyxa flaccida
Ophiactis miilleri
Ophiothrix angulata
Ophiothrix öerstedii
Ophiothrix suensonii
Ophionereis reticulata
Ophiocoma echinata
Ophiocoma pumila

Ophiocoma riisei

Ophioderma appressa

Ophioderma brevicauda

Ophioderma cinerea

Ophioderma mbicunda

Ophiura acervata

Ophiomusium validum

ophiolepis elegans

Ophiolepis paucispina 


\section{THE WEST INDIAN OPHIURAN FAUNA}

There are known from the recent seas 1420 described species of ophiurans representing 192 genera which are distributed among 13 families.

In the West Indian region there occur 255 species representing 88 genera and all the known families.

Whereas in the case of the crinoids all the species occurring in the Caribbean region are confined to that area, a considerable number of the ophiurans occur more or less generally throughout the Atlantic basin, or are represented by closely related types in the east Atlantic and Mediterranean Sea, and some are almost universally distributed.

As examples of wide ranging forms the following may be mentioned.

Amphipholis squamata, which is found from Norway to the Cape of Good Hope, on both sides of the Atlantic, and from Australia and New Zealand to Juan Fernandez, California and Hawaii.

Amphiura otteri, occurring on both coasts of the north Atlantic and in Lower California.

Ophiactis savignyi, occurring in shallow water in all warm seas.

Ophiacantha vepratica, found in the West Indies and in Fiji.

Ophiomusium lymani, occurring everywhere in water of moderate depth and temperature.

Ophiomusium planum, found on both coasts of the middle Atlantic and in the Indian Ocean.

Amphiophiura sculptilis, found in the West Indies, the Indian Ocean, the East Indies and Japan.

Asteronyx loveni, found in all northern seas and southward to the West Indies, Lower California and Japan.

The following 21 genera are known from the Caribbean region only; those marked with an asterisk (*) are monotypic.

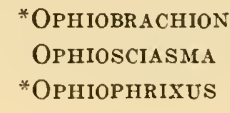

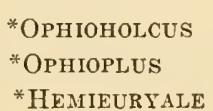

*Hemieuryale 
* Astrocnida

* Astrophytum

* Astrogordius

*Astrocyclus

*Astrocynodus

[ OPHIOCHONDRUS]

*OPHIOCHONDRELLA
OPHIOMITRA

* Ophiacanthella

* MicrophiURA

*OphioblenNa

*Ophionema

*OPHIOTHYREUS

*A MPHIPHOLIZONA

* OPH IOP EPALE

While a number of these genera will undoubtedly eventually be found in other parts of the world, still the fact that they represent $24 \%$ of the total number of genera occurring in the West Indies is significant, and the fact that all but three of them, or $83 \%$, are monotypic is still more so.

The existence in the West Indian region of these endemic genera indicates that this region constitutes a very marked faunal entity, while the occurrence of so many monotypic genera suggests that faunal stability was attained a long while ago; in other words that, as compared to the other portions of the oceans, faunal evolution has been retarded so that the West Indian region may be described as faunally the most ancient portion of the recent seas.

So far as we are able to judge from the geological record, taken in connection with the recent fauna, there are two quite distinct types of distribution, always, however, more or less superimposed, in every homogeneous animal group.

A newly arisen animal type immediately spreads to the limits of its possible distribution, and within the area overrun by it all sorts of variants appear which may be considered as of varietal, subspecific or specific value.

Thus a genus or any other homogeneous group represented in a given faunal district by a number of closely related types is a group of recent origin, or of recent introduction.

As time passes a number of factors begin to assert themselves, internal and external parasitisı, economic pressure of great numbers of individuals, and economic pressure of competing types, which tend to restrict the possible scope of variation and to confine the variants within well marked limits which constantly become narrower and narrower until only a few well marked and distinct types remain each of which has now acquired the status of a monotypic genus. 
Thus a group of animals represented in a given region wholly or chiefly by a number of very distinct types, or monotypic genera, has been more or less isolated in that region for a very considerable period.

It is interesting to compare the occurrence of the opliurans in the Caribbean region with that of the crinoids.

Total number of ophiuran families, 13 ; of crinoid families, 28.

Total number of ophiuran genera, 192; of crinoid genera, 142.

Total number of ophiuran species, 1420 ; of crinoid species, 576 .

Ophiuran families in the West Indies, 13; percent of total, 100.

Crinoid families in the West Indies, 16 ; percent of total, 54 .

Ophiuran genera in the West Indies, 88 ; percent of total, 46.

Crinoid genera in the West Indies, 30 ; percent of total, 21.

Ophiuran species in the West Indies, 255 ; percent of total, 18.

Crinoid species in the West Indies, 51 ; percent of total, 9.

Endemic ophiuran genera, 21; percent of total in West In. dies, 24.

Endemic crinoid genera, 16 ; percent of total in West Indies, 53.

Monotypic ophiuran genera, 18; percent of total in West Indies, 20.

Monotypic crinoid genera, 11 ; percent of total in West Indies, 37.

The recognized families and subfamilies in the recent crinoids are in almost all cases better differentiated than the same divisions among the ophiurans as we understand them now. This indicates a phylogenetic advancement of the crinoid over the ophiuran fauna whereby the former has become more definitely crystallized into well circumscribed types.

The relationships of the ophiuran and crinoid families, genera and species may be analyzed as follows:

$\begin{array}{lcc} & \text { OPHIURANS } & \text { CRINOIDS } \\ \text { Number of families } & 13 & 28 \\ \text { Average number of genera per family } & 16 & 5 \\ \text { Average number of species per genus } & 7 & 4\end{array}$


The greater number of erinoid families indicates that the recent crinoid fauna, if not actually older than the recent ophiuran fauna, at least developed earlier, as the various forms have become more definitely circumscribed and segregated into well differentiated units. The relative state of undevelopment of the ophiuran fauna is also indicated by the much larger number of genera in each family and of species in each genus, as well as by the larger number of species in each genus in any given locality.

Only about one-half of the higher groups of crinoids are represented in the West Indies, while all of the higher groups of ophiurans occur there. One crinoid family, the Holopodidæ, is known only from the Caribbean Sea. Assuming that the Malayan region is the present center of distribution for marine animals and the place of origin of most recent types, this is easily accounted for by the much greater facilities for dispersal possessed by the vast majority of the ophiurans, through their pelagic young.

Only $21 \%$ of the known crinoid genera are found in the West Indies, while $46 \%$, or more than twice as many, of the ophiuran genera occur there. This also is probably due to the greater facilities for dispersal possessed by the ophiurans.

Of the known ophiuran species $18 \%$ occur in the West Indies, as against $9 \%$, half as many, of the known crinoids. This would scem to indicate that as the Caribbean erinoid fauna had grown old and become crystallized along definite lines no new accessions had come in from the rapidly developing fauna of the Malayan region, whereas the interchange of ophiurans from east to west has kept the ophiuran fauma younger.

Among the crinoids $53 \%$ of the Caribbean genera are not represented elsewhere, while among the ophiurans the number is less than half as large, only $24 \%$. This is the result of the erystallization of the West Indian crinoid fauna and the lack of interchange with other faunas, which has taken place to a much greater degree than in the case of the ophiurans.

Exactly the same explanation holds for the fact that $37 \%$ of the endemic genera of crinoids are monotypic, while only about half as many of the ophiuran genera, $20 \%$, are monotypic.

The 192 genera of ophiurans may be classified according to their geographical ranges as follows: 
Universally distributed, or occurring in all warm seas..68

Indo-Malayan region only $\ldots \ldots \ldots \ldots \ldots \ldots \ldots \ldots . \ldots \ldots$

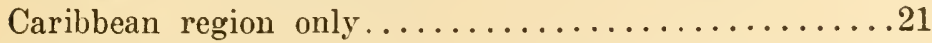

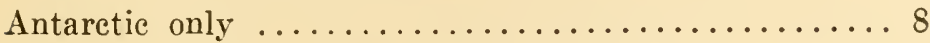

South Australia, Tasmania and New Zealand....... 7

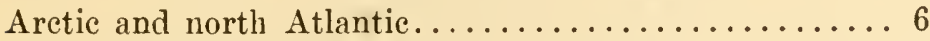

North Pacific .......................... 5

North Pacific and north Atlantic............... 3

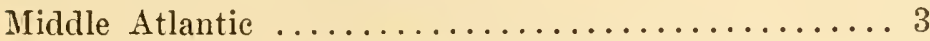

Caribbean Sea and west coast of Central America..... 3

Peru to southern California.................. 3

Caribbean Sea to Galapagos Islands.............. 1

Caribbean Sea and Nediterranean............... 1

Indo-Pacific and Mediterranean................ 1

Southern California and New Zealand............ 1

[Unclassified .......................... 4]

In order fully to understand the affinities of the West Indian ophiuran fauna the following apparently anomalous ranges of certain genera, supplemented by similar eases among the starfishes and echinoids, must be considered.

Warmer parts of the eastern and western Atlantic; Mexico to Chile

$$
\text { Narcissia Arbacia }
$$

Both coasts of tropical America

ENCOPE

Mellita

West Indies and western coast of Central America

HEMIPHOLIS

OPHIOCRYPTUS

OPHIOZONA

West Indies and Galápagos Islands (probably in reality the same as the preceding)

SigSBeia

Peru to southern California (some only in part)

$\begin{array}{lc}\text { Astrocaneui } & \text { Paulia (Galápagos Islands } \\ \text { Diopederma } & \text { also) } \\ \text { Gymnophiura } & \text { Pharia } \\ \text { Platasterias } & \text { Phataria }\end{array}$


Nidorellia

HELIASTER

AMPHIASTER

\author{
C.enocentrotus (Galápagos \\ Islands also) \\ TETRAPYGUS
}

West Indies and eastern Atlantic; Hawaiian Islands; southern Japan; Kei Islands

\section{CANOPEDINA}

Western coast of Mexico; Hawaiian Islands; Australia, Tasmania and Lord Howe Island; Mediterranean Sea and eastern Atlantic

\section{CEntrostephanus}

Southern and Lower California, southern Japan, and southern Australia

\section{HELIOCIDARIS}

West Indies and the Hawaiian Islands

\section{PODOCIDARIS}

West Indies and southern Australia

\section{OPHIOPRIUM}

\section{Southern California and New Zealand}

\section{OPHIOPTERIS}

In view of the past intercommunication between the Caribbean Sea and the Pacific the similarity of certain elements of the Caribbean fauna and of that of the western coast of tropical America is not surprising; the latter, however, includes a very considerable number of genera which occur nowhere else, together with a few species of characteristic Indo-Malayan types, such as Mithrodia, Acanthaster, Anthenea, Leiaster, Astropyga, ete., which are not represented in the Caribbean Sea.

A significantly large number of genera, including well known and conspicuous littoral types, inhabit a more or less extensive portion of the following anomalous range-Mediterranean Sea, Caribbean Sea, southern Australia and New Zealand, southern Japan, the Hawaiian Islands, and the western coast of tropical America.

This discontinuous range, though indicated by very diverse types and only in part by each, nevertheless must be considered a zoögeographic unit. Its outstanding feature is the fact that it 
represents the extreme outer limits of a tropical and subtropical faunal region the center of which is the Indo-Malayan region.

The types inhabiting it, that is to say occurring only on the extreme periphery of the Indo-Pacific faunal area (of which the Nediterranean Sea was at one time a part) may be considered, therefore, as relics of a previous fauna at one time characteristic of the central Indo-Malayan region from which they have now been extirpated through the competition of younger and more efficient types.

The same facts are brought out equally well in many other groups of marine animals, and are also reflected in a modified way in the terrestrial faunas.

In the faunas of the colder seas all intergradations are found between types which are quite unique, and types differing little or not at all from others in the Indo-Malayan region, and this intergradation is complete enough so that we are justified in considering the fauna of the colder waters as similarly ultimately derived from the (past or present) fauna of the East Indian region largely through the intermediary of deep water forms. Some of these genera of the colder waters, as Astriclypeus and GLYPTOCIDARIS, are extraordinarily restricted in their distribution and rare, while others are abundant and widely spread.

One of the peculiarities of the West Indian ophiuran fauna is the relatively poor representation of Ophiotrichidæ. This family includes 13 genera and 157 species of which 126 belong to the genus OpHIOTHRIx, occurring in all the warmer portions of the recent seas and represented by 7 species in the West Indies. One monotypic genus, OPHIOTRICHOIDEs, is only known from the Cape Verde Islands, but the remaining 11 genera are exclusively Indo-Malayan. All of the species of this family are more or less conmmensal in habit, and some are almost parasitic. The species of four of the genera, Opнiомaza, Oрніожтніор, OрніорнтніrIUS and Ophiosphera, live upon comatulids. In one genus, Ophiopteron, the arm spines are webbed together and resemble little fins which has given rise to the idea that it is able to swim.

The greatest mystery connected with the Caribbean ophiurans concerns the genus OPHIOblenna. The only known species, Ophioblenna antillensis, was deseribed in 1859 from two specimens collected at Water Island, St. Thomas. In spite of all the 
collecting that has since been done in the West Indies, and even at Water Island itself, no others have ever come to light.

\section{THE OPHIURANS OF THE CARIBBEAN REGION}

Those designated with an asterisk (*) have been recorded from Barbados.

\section{Family Ophiomyxidæ}

Ophiomyxa flaccida

* Ophiomyxa tumida

Ophiomyxa brevicauda

* Ophiobyrsa serpens

Ophiobyrsa perrieri

Ophiobrachion uncinatus

* Ophiogeron supinus

* Ophiosciasma granulatum
Ophiosciasma attenuatum

Ophiophrixus quadrispinosus

Ophiodera stimpsonii

Ophioscolex disacanthus

* Ophioscolex glacialis

*Ophioscolex tropicus

Ophioscolex serratus

Ophioleptoplax atlantica

\section{Family Trichasteridæ}

*Astroschema arenosum Astroschema intectum Astroschema brachiatum

* Astroschema loeve

*Astroschema oligactes Astroschema sulcatum

* Astroschema tenue Astroschema clavigerum
Astroschema elongatum Astroschema nuttingi Astroschema vicinum *Ophiocreas lumbricus Ophiocreas oedipus *Ophiocreas spimulosum Asteronyx lovéni Astrodia tenuispina

\section{Family Gorgonocephalidæ}

Astrogomphus vallatus Astrogomphus rudis

* Asteroporpa anmulata

* Asteroporpa pulchra

*Astrocnida isidis
Astrospartus mucronatus Astrophytum muricatum Astrogordius cacaoticus *Astrocyclus cacilia Astrocynodus herrarai

\section{Family Hemieuryalidæ}

Ophiochondrus armatus

* Ophiochondrus convolutus

Ophiochondrus crassispinus

ophiochondrus gracilis
Ophiochondrella squamosa

* Sigsbeia murrhina

Ophioholcus sexradiatus

Ophioplus tuberculosus

*Hemieuryale pustulata 


\section{Family Ophiacanthidæ}

Ophiolebes claviger

Ophiolebes humilis

Ophiacantha anomala

* Ophiacantha aspera

Ophiacantha bidentata

Ophiacantha cosmica

Ophiacantha curima

Ophiacantha echinulata

* Ophiacantha hirsuta

Ophiacantha lineata

* Ophiacantha mesembria

* Ophiacantha metallacta

Ophiacantha oligacantha

Ophiacantha ophiactoides

* Ophiacantha pentacrimus

Ophiacantha robusta

* Ophiacantha scutata

* Ophiacantha stellata

* Ophiacantha valenciennesi

Ophiacantha affinis

Ophiacantha levis

Ophiacantha segesta

Ophiacantha vepratica.

Ophiothammus chariis

* Ophiothamnus exiguus

Ophiothamnus vicarius
Ophiomitrella lcevipellis

Ophiomitrella glabra

* Ophiomitra valida

Ophiomitra ornata

* Ophioplinthaca incisa

Ophioplinthaca chelys

Ophioplinthaca dipsacos

Ophioplinthaca spinissima

* Ophiocamax fasciculata

* Ophiocamax hystrix

Ophiocamax austera

* Ophiacanthella troscheli

Ophioprium cervicorne

Ophioprium imperfectum

Ophioprium permixtum

Ophiotreta lineolata

Ophiotreta mixta

* Ophiotreta sertata

Ophiotreta littoralis

Ophialcae nuttingi

Ophiotoma bartletti

Ophiotoma gracilis

Ophioconis miliaria

* Ophiohelus umbella

Microphiura decipiens

ophioblenna antillensis

Ophiologimus secundus

\section{Family Ophiomycetidæ}

* Ophiomyces frutectosus

Ophiomyces mirabilis

Ophiotholia mitrephora

\section{Family Amphiuridæ}

* Amphiura goniodes

Amphiura grandisquamata

Amphiura lunaris

Amphiura otteri

Amphiura linbergiensis ophiochytra tenuis

Amphiodia atra

Amphiodia gyraspis

Amphiodia limbata

Amphiodia planispina 
* Amphiura palmeri

Amphiura semiermis

* Amphiura stimpsonii Amphiura bihamula Amphiura complanata Amphiura crassipes Amphiura diducta Amphiura fibulata Amphiura flexuosa Amphiura kiikenthali Amphiura rathbuni Amphiura vivipara Hemipholis elongata Ophiophragmus brachyactis Ophiophragmus pulcher Ophiophragmus lütkeni Ophiophragmus würdemanni Ophiophragmus filogranea Ophiophragmus septa Ophionephthys limicola Ophionema intricata Amphipholis abnormis Amphipholis gracillima Amphipholis pachybactra Amphipholis pentacantha Amphipolis squamata Amphipolis subtilis Ophiostigma isacanthum

Amphiodia pulchella Amphiodia repens Amphiodia rhabdota Amphiodia riisei Amphiodia trychna Amphiodia lütkeni Amphiodia tymbara Ophiocnida lovéni ophiocnida scabriuscula ophiocnida cubana Ophiocnida scabra Amphioplus abditus Amphioplus agassizii Amphioplus coniortodes Amphioplus cuneata Amphioplus incisa Amphioplus nereis Amphioplus thrombodes Amphioplus tumida Amphioplus verrilli Amphilimna olivacea Amphilimna caribea Ophiactis cyanosticta * Ophiactis duplicata *Ophiactis mülleri Ophiactis plana Ophiactis savignyi Ophiactis lymani

Ophiactis loricata

\section{Family Ophiotrichidæ}
*Ophiothrix angulata
Ophiothrix angulata megal- aspis
Ophiothrix brachyactis

Ophiothrix lineata

*Ophiothrix oerstedii

Ophiothrix pallida

*Ophiothrix suensonii

Ophiothrix rathbuni

\section{Family Ophiochitonidæ}

Ophiochiton grandis

*Ophionereis reticulata 
*Ophioplax ljungmani

Ophionereis olivacea

ophioplax reducta

Ophionereis squamulosa

\section{Family Ophiocomidæ}

* Ophiocoma echinata

* Ophiocoma pumila

* Ophiocoma riisei

Ophiopsila fulva
*Ophiopsila hartmeyeri

*Ophiopsila polysticta

*Ophiopsila riisei

Ophiopsila maculata

Ophiopsila vittata

\section{Family Ophiodermatidæ}

*Ophioderma appressa

*Ophioderma brevicauda

* Ophioderma brevispina

* Ophioderma cinerea

Ophioderma elaps

Ophioderma guttatum

Ophioderma holmesi

?Ophioderma januarii

Ophioderma clypeata
Ophioderma rubicunda

Ophioderma pallidum

Ophiomusium rugosum

Ophioderma squamosissima

Ophiocryptus dubius

Ophiarachnella angulata

ophiarachnella petersi

Bathypectinura lacertosa

Bathypectinura tessellata

\section{Family Ophiolepididæ}

*Ophiomastus secundus Amphiophiura bullata ?Amphiophiura convexa Amphiophiura coronata Amphiophiura fasciculata Amphiophiura metabula Amphiophiura oedignatha Amphiophiura sculptilis Amphiophiura scutata Stegophiura macrarthra * Ophiura acervata

* Ophiura falcifera Ophiura irrorata Ophiura lepida Ophiura ljungmani Ophiura tenera ?Ophioglyphina robusta
Ophiomusium planum

Ophiomusium dugosum

*Ophiomusium serratum

* Ophiom usium testudo

*Ophiomusium validum

Ophiomusium sculptum

Ophiomusium stellatum

Ophiomisidium speciosum

Ophiomisidium pulchellum

Ophiolipus agassizii

Ophiophyllum petilum

Ophiothyreus goësii

* Amphipholizona delicta

*Ophioceramis albida

*Ophioceramis januarii

* Ophiozona impressa

* Ophiozonella antillarum 
Homalophiura abyssorum

Homalophiura inornata

*Ophiomusium acuferum

Ophiom usium armigerum

* Ophiomusium eburneum

Ophiomusium lymani

*Ophiomusium monoplax

Ophiomusium oligoplacum
Ophiozonella clypeata

* Ophiozonella marmorea

* Ophiozonella nivea

Ophiozonella nivea compta

* Ophiozonella tessellata

Ophiomidas dubius

Ophiolepis elegans

*ophiolepis paucispina

\section{Family Ophioleucidæ}

Ophioleuce depressa.

* Ophiopcrpale goësiana
Ophiopyren longispinus

*ophiernus adspersus

The following names are based upon color varieties:

Amphiura vivipara var. anmulata $\mathrm{H}$. L. Clark Ophiothrix oerstedii var. lutea H. L. Clark Ophiothrix angulata var. atrolineata $\mathrm{H}$. L. Clark Ophiothrix angulata var. violacea Müller and Troschel Ophiothrix angulata var. phoinissa $\mathrm{H}$. L. Clark Ophiothrix angulata var. phlogina H. L. Clark Ophiothrix angulata var. poecila H. L. Clark

\section{THE OCCURRENCE OF OPHIURANS AT BARBADOS} AND AT ANTIGUA

In his account of the natural history of Barbados published in 1750 the Reverend Griffith Hughes wrote under the heading "The Sea Scorpion," "What we call here the Scorpion is by Petiver called Stella marina Scolopendroides. Its five rays might perhaps properly cause it to be called the Stella marina." This is the only ophiuran mentioned by Hughes.

The Sea Scorpion, Ophiocoma echinata, still called by the same name, I found to be abundant in 1903, and Professor Nutting states that it occurs almost literally under every stone and scuttles away with amazing celerity when disturbed. It was the most abundant and conspicuous form of animal life under the loose coral rocks uncovered at low tide on both sides of the laboratory at Pelican Island. It is most commonly brown in color, with the club shaped spines almost black. The disk shows great variation, often having a central oval or pentagonal area of 
cream color showing in sharp contrast to the dark brown spines. Besides Ophiocoma echinata, $O$. riisei and $O$. pumila were secured, but were much less abundant. Professor Nutting also mentions the common association of Ophiocoma echinata with Echinometra viridis.

The species of Ophiocoma were the most common ophiurans along the shores at Barbados, although several other species were more or less abundant.

Three species of Ophiothrix, $O$. angulata, $O$. oerstedii and $O$. suensonii, the last named the most abundant, fairly swarmed over some of the gorgonians brought up near Hastings by the diver. Often the large profusely branched gorgonians were fairly covered with the wriggling ophiurans.

Professor Nutting writes that one of the most beautiful serpent stars he ever saw was taken at Station 64, in from 60 to 70 fathoms. It was a large specimen with a spread of about ten inches, with a very distinct band of vivid crimson on a background of light pink along the dorsal surface of the arms and extending to the center of the disk. The spines were very slender, $8 \mathrm{~mm}$. long, quite transparent, with saw-like sides and in three series on each side of the arms. This individual has not come to hand, but undoubtedly it was a particularly fine example of Ophiothrix suensonii.

Of the simple armed basket fish Professor Nutting says that perhaps the most conspicuous and strikingly marked were Asteroporpa and Astrocnida from deep water. The arms in Asteroporpa are unbranched, while those of Astrocnida from Stations 55 , in - fathoms, and 89, in 80 fathoms, are slightly branched at the tip and ornamented throughout with transverse elevated bands of light gray alternating with depressed bands of deep chocolate. These circular ridges are beset with thorny stubby spines. The bases of the arms are swollen, and the swellings invade the dorsal surface of the disk in the center of which is a star shaped area formed by similar ridges. Another simple armed basket fish, Astroschema oligactes, is from Station 7, and is orange colored and exceedingly hispid all over, feeling like coarse sandpaper, wiry in texture, with arms tapering to a mere coiled thread which can wind itself closely around a support and cling there most tenaciously. A certain flabellate red and white 
gorgonian was very common in the dredging and almost always a species of simple armed basket fish (Astroschema, spp.) was coiled closely around the branches which it matched so perfectly in color that it was very apt to be overlooked. The protective coloration is so commonly found in serpent stars living as symbionts on alcyonarians that many writers have noticed it.

Professor Nutting says that at Antigua "our favorite collecting ground was near what we called 'Rocky Point,' across from Barclay Point and inside of the Pillars of Hercules. . . . . The echinoderms were perhaps the most conspicuous group at this place, although most of the species were the same as those secured at Barbados. At the foot of the Pillars of Hercules certain species found a refuge in the cracks of the rocks that were continually being scoured by the waves. On these rocky flats everything seemed to be stuck tight and had to be forcibly pried loose. There were small holothurians that wedged themselves in these eracks and held on with remarkable tenacity."

\section{OPHIURANS PREVIOUSLY OBTAINED AT BARBADOS}

The Ophiurans collected by the "Hassler" at Barbados in 100 fathoms

$\begin{array}{ll}\text { Astroschema oligactes } & \text { Ophiothrix angulata } \\ \text { Astroschema tenuis } & \text { Ophiothrix suensonii } \\ \text { Asteroporpa annulata } & \text { Ophioplax ljungmani } \\ \text { Astrocnida isidis } & \text { Ophiura acervata } \\ \text { Ophiacantha hirsuta } & \text { Ophiomusium acuferum } \\ \text { Ophiacantha stellata } & \text { Ophiomusium testudo } \\ \text { Ophiomitra valida } & \text { Ophioceramis albida } \\ \text { Amphiura palmeri } & \text { Ophioceramis januarii } \\ \text { Ophiomyces frutectosus } & \text { Ophiozonella nivea } \\ \text { Ophiactis duplicata } & \text { Ophiopapale goësiana }\end{array}$

The Ophiurans collected at Barbados by the "Blake" Station 272; 76 fathoms
Ophiomyxa tumida
Ophiactis mülleri
Astroschema lave
Ophiothrix suensonii
Astroschema oligactes
Ophiomusium acuferum
Asteroporpa annulata
Ophiomusium testudo 
Ophiomitra valida

Ophiactis duplicata
Amphipholizona delicata

Ophiozona impressa

ophiopapale goësiana.

Station 273; 103 fathoms

Ophioscolex tropicus

Ophioplax ljungmani

Astroschema lave

Ophiomusium acuferum

Asteroporpa annulata

Ophiomusium testudo

Ophiacantha hirsuta

Amphipholizona delicata

Ophiacantha stellata

Ophiozonella marmorea

Ophiactis duplicata

Ophiozonella nivea

Ophiozonella tessellata

Station 274; 209 fathoms

Ophiocamax hystrix

Ophiotreta sertata

Ophiomusium acuferum

Ophiactis duplicata

Ophiomusium eburneum

Ophiomusium serratum

Ophiozonella nivea

Station $275 ; 218$ fathoms

Ophiactis duplicata

Station 276; 94 fathoms

Ophiomyxa tumida

Astroschema lave

Astroschema oligactes

Astroschema tenue

Asteroporpa annulata

Hemieuryale pustulata
Ophiactis duplicata

Ophiothrix suensonii

Ophionereis reticulata

Ophiomusium acuferum

Ophiomusium testudo

Ophiozona impressa

Ophiozonella antillarum

Station 277; 106 fathoms

Asteroporpa annulata

Sigsbeia murrhina

Hemieuryale pustulata
Ophiomitra valida

Ophiothrix suensonii

Ophioplax ljungmani

Ophiomusium acuferum

Station 278; 69 fathoms

ophiomyxa tumida

Ophionereis reticulata

ophiobyrsa serpens

Ophioderma cinerea 
Astroschema oligactes

Amphiura stimpsonii

Ophiactis miilleri
Ophiomusium acuferum

Ophiomusium testudo

Ophiozona impressa

Station $279 ; 118$ fathoms

\section{Ophiocreas spinulosum}

Station $280 ; 221$ fathoms

Ophiochondrus convolutus

Ophiotreta sertata

Ophiacantha pentacrinus

Ophiomusium eburneum

Ophiocamax hystrix Ophiomusium serratum

Ophiozonella nivea

Station 281; 288 fathoms

ophiomyxa tumida

Astroschema arenosum

Ophiocreas lumbricus

Ophiocreas spimulosum

Station $282 ; 154$ fathoms

ophiomyces frutectosus

Station $283 ; 237$ fathoms

Ophiacantha aspera
Ophiacantha scutata Ophiomyces frutectosus Amphiophiura fasciculata Ophionusium acuferum

Ophiomitra valida

Station $285 ; 13-40$ fathoms
Ophiomyxa tumida
Ophiothrix suensonii
Ophiothrix angulata
Ophiopsila riisei

Ophiozonella tessellata

Ophiacantha valenciennesi Ophioderma brevispina

Station $286 ; 7-45$ fathoms

Ophiothrix suensonii

Station 287; 71/2-50 fathoms

Ophiopsila polysticta

Station 288; 399 fathoms

Ophiacantha metallacta

Ophiacantha pentacrinus

ophioplinthaca incisa

Amphivra goniodes
Ophiomastus secundus

Ophiomusium monoplax

Ophiozonella antillarum

Ophiernus adspersus 
Station 290; 73 fathoms

ophiomyxa tumida

Astroschema lave

Astroschema oligactes

Asteroporpa anmulata

Astrocnida isidis

Astrocyclus coecilia

Ophiacantha aspera
Ophiacantha stellata

Ophiomitra valida

Ophiocanthella troscheli

ophiactis duplicata

Ophiothrix suensonii

Ophiomusium acuferum

Ophiomusium testudo

Ophiozonella tessellata

Station $291 ; 200$ fathoms

Ophiomyxa tumida

Ophiogeron supinus

Ophiacantha pentacrinus

Ophiacantha scutata

Ophiocamax hystrix

Ophiotreta sertata

Station 292; 56 fathoms

Astroschema lave

Asteroporpa annulata

Astrocnida isidis

Ophiacantha stellata

Station 293; 82 fathoms

ophioscolex glacialis

Ophiacantha hirsuta

Ophiacantha stellata
Ophiura falcifera

Ophiomusium acuferum

Ophiomusium validum

Ophiozonella antillarum

Ophiozonella nivea

Ophiernus adspersus

Ophiothrix angulata

Ophiothrix suensonii

Ophiomusium acuferum

ophiozonella nivea

Ophiothrix suensonii

Ophiomusium acuferum

Amphipholizona delicata

Ophioprepale goësiana

Station 294; 137 fathoms

Ophiothrix suensonii

Ophiozonella nivea

Station 295; 180 fathoms

Ophiocamax fasciculata

Station 296; 84 fathoms

Ophiomyxa tumida

Astroschema lave

Astroschema oligactes

Asteroporpa amulata

Astrocnida isidis
Astrocyclus cacilia

Hemieuryale pustulata

Ophiothamnus exiguus

Ophiomitra valida

Ophiomusium acuferum 
Station $297 ; 123$ fathoms

Astroschema oligactes

Asteroporpa annulata

Ophiomitra valida

Ophiotreta sertata

Station 298; 120 fathoms

Astroschema oligactes

Asteroporpa annulata
Ophioplax ljungmani
Ophiomusium acuferum
Ophiozonella tessellata
Ophiopcepale goesiana

Ophiozona impressa

Station 299; 140 fathoms

Ophiacantha pentacrinus Ophiomusium acuferum Ophiozonella tessellata

Station $300 ; 82$ fathoms

Ophiacantha hirsuta Ophiohelus umbella

Ophiomusium acuferum

Ophiuran recorded as in Sir Rawson W. Rawson's collection: Astrocyclus cecilia

Ophiurans recorded from Barbados by Professor René Koehler in 1907 :
Ophioplax ljungmani
Astrocyclus ccecilia
Ophioscolex glacialis;
82 fathoms

Ophiurans recorded from Barbados by Professor Køhler in 1913 :
Ophioderma appressa
Ophiocoma echinata
Ophioderma brevicauda
ophiocoma riisei
Ophioderma cinerea
Ophiocoma pumila
Ophiozona impressa
Ophiothrix angulata
ophiolepis paucispina
Ophiothrix oerstedii
ophionereis reticulata
Ophiothrix suensonii

Ophiurans recorded from Barbados by Professor Kohler in 1914: 
Ophiurans recorded from Barbados by Dr. Hubert Lyman Clark in 1915:

Ophiosciasma granulatum, $94 \mathrm{fms}$.

Asteroporpa pulchra, 56-125 fms.

Ophiacantha mesembria, 140-221 fms.

Amphiura palmeri, 100 fins.

Ophiopsila polysticta, 71/2-50 fms.

Ophiopsila hartmeyeri, $69 \mathrm{fms}$.

Amphipholizona delicata, 76-103 fms.

Ophiomusium monoplax, 399 fms.

Ophiozonella marmorea, $103 \mathrm{fms}$.

\section{ANNOTATED LIST OF THE SPECIES OBTAINED}

Ophiurans collected by the Barbados-Antigua Expedition from the State University of Iowa, together with the collecting stations listed by the Expedition:

\section{ANNOTATED LIST OF THE SPECIES OBTAINED Order PHRYNOPHIURIDA}

\section{Family Ophiomyxidæ}

OPHIOMYXA FLACCIDA (Say)

Pelican Island, Barbados; tide pools.-One specimen.

English Harbour, Antigua.-One specimen.

Ophiosciasma granulatum Lyman

Station 26: One specimen.

\section{Family Trichasteridæ}

Astroschema arenosum Lyman

Station 46: Two specimens.

\section{Astroschèma Laeve Lyman}

Station 36: One specimen.

Astroschema oligactes Lütken

Station 7: Five specimens.

Station 34: One specimen.

Station 35: One specimen. 


\section{Astrochema tenue Lyman}

Station 59: part of an arm.

\section{Family Gorgonocephalidæ}

Asteroporpa annulata Lütken

Station 7: One specimen.

Station 41: One small specimen.

Station 58: One small specimen.

Astrocnida isidis Lyman

Station 55: One specimen.

Astrophytum muricatum (Lamarck)

Carlisle Bay, Barbados; 20 feet; found on a gorgonian.-One small specimen with the disc $14 \mathrm{~mm}$. in diameter.

Carlisle Bay, Barbados; 5 fathoms.-One small specimen with the dise $12 \mathrm{~mm}$. in diameter.

Barbados; from fish pots.-Two specimens, one with the dise about $50 \mathrm{~mm}$., the other with the disc $30 \mathrm{~mm}$. in diameter.

\section{Astrocyclus cacilia (Lütken)}

Station 97: One small specimen with the disc $8 \mathrm{~mm}$. in diameter.

\section{Order LAMOPHIURIDA \\ Family Hemieuryalidæ}

Sigsbeia murrhina Lyman

Station 97: Four very small specimens, the largest with the dise $4 \mathrm{~mm}$. in diameter.

\section{Ophioplus tuberculosa (Lyman)}

Barbados.-One specimen.

\section{Hemieuryale pustulata von Martens}

Station 2: Two specimens.

Station 36: One specimen.

Station 51: Six specimens.

Station 57: Fifteen specimens.

Station 64: One specimen.

Station 70: Six specimens.

Station 82: One small specimen. 


\section{Family Ophiacanthidæ}

Ophiacantha mesembria H. L. Clark

Station 9: Two small specimens.

Station 15: One specimen.

Station 28: Four small specimens.

Station 37: Two small specimens.

Station 59: One specimen.

Order GNATHOPHIURIDA

Family Amphiuridæ

Amphiura diducta Kœhler

Station 1: One specimen.

Amphiura palmeri Lyman

Station 96: Two specimens.

Amphipholis limbata (Grube)

Station 79 : One specimen.

Amphiodia planispina (von Martens)

Station 1: One specimen, with the disc lacking.

Ophiactis miilleri Lütken

Station 11: One specimen.

Station 67: Two specimens; one of these has three mouth papillæ.

Station 101: Twenty-two specimens.

No locality: Two specimens.

Ophiactis savignyi Müller and Troschel

Station 1: One specimen.

$$
\text { ophiactis duplicata (Lyman) }
$$

Station 6: Three specimens.

Station 45: One specimen.

\section{Family Ophiotrichidæ}

Ophiothrix angulata Ayres

Station 1: Six specimens.

Station 11: Eight specimens.

Station 13: One specimen. 
Station 18: One specimen.

Station 51: One specimen.

Station 65: One specimen.

Station 67: Three specimens.

Station 70: One specimen.

Station 78: Two specimens.

Station 85: Two specimens.

Station 96: Three specimens.

Station 100: Five specimens.

Barbados; Engineers' Pier, 15-20 feet.-Fragments.

Barbados; off Pelican Island, 4 fathoms; from gorgonians and corals.-Seven specimens.

Barbados; off Pelican Island, 50 feet.-One small specimen.

Barbados; off Needham's Point; diver.-Eight specimens.

Station 101: Four specimens.

Antigua; English Harbour; in eel grass.-Two specimens.

Ophiothrix lineata Lyman

Barbados; off Pelican Island, 4 fathoms; from gorgonians and corals.-One specimen.

\section{Ophiothrix oerstedii Lütken}

Barbados ; Engineers' Pier, 15-20 feet; from gorgonians; May 18, 1918.-Two specimens.

Barbados; Needham's Point; diver.-Ten specimens.

Antigua; English Harbour; in eel grass.-Three specimens.

Antigua; English Harbour; rocks.-One specimen.

Ophiothrix suensonii Lütken

Station 53: One specimen.

Station 59: One specimen.

Station 62: One specimen with the dise $14 \mathrm{~mm}$. in diameter; the spines on the dise are much more numerous and shorter than usual. In life the dise was olive gray with five radial red bands, and the arms were whitish with the dorsal arm plates dark coral red and the ventral plates lighter.

Station 89: One specimen.

Barbados ; Engineers' Pier, 15-20 feet; from gorgonians; May 18, 1918.-Fifty-four specimens.

Barbados; off Pelican Island.-Two specimens. 
Barbados; off Pelican Island, 4 fathoms; from gorgonians and corals._Thirteen specimens.

Barbados; Carlisle Bay, 20 feet; on gorgonians.-Twenty-nine specimens.

Barbados; off Needham's Point; diver.-Twenty specimens.

Barbados; off Hastings; June 5, 1918.-Thirteen specimens.

Station 101: Two specimens.

Antigua; English Harbour.-Seven specimens.

Ophiothrix pallida Ljungman

Station 96: Two specimens.

Order CHILOPHIURIDA

Family Ophiochitonidæ

Ophionereis reticulata (Say)

Station 1: Three specimens.

Station 67: One specimen.

Station 70: One specimen.

Station 79: One small specimen.

Station 101: One specimen.

Antigua; English Harbour.-Seven specimens.

\section{Family Ophiocomidæe}

ophiocoma echinata L. Agassiz

Station 96: One specimen.

Barbados; Pelican Island; tide pools.-One specimen.

Barbados; Bathsheba; tide pools.-Eleven specimens.

Station 101: One specimen.

Antigua; English Harbour; rocks.-Three specimens.

Antigua; English Harbour; in eel grass.-One specimen.

Antigua; English Harbour.-Fifteen specimens.

Antigua.-One specimen.

Ophiocoma pumila Lütken

Station 96: One specimen.

Barbados; Pelican Island; tide pools; May 11, 1918.-Four specimens.

Barbados; Pelican Island.-One specimen.

Barbados; Needham's Point; June 8, 1918.-Four specimens. 
Antigua; English Harbour; rocks.-Fifteen specimens.

Antigua; English Harbour.-Ten specimens.

\section{Ophiocoma riisei Lütken}

Station 1: Five specimens.

Station 96: Two specimens; one of these, small and without granules on the disc, was kindly identified for me by Dr. H. L. Clark.

Station 100: Three specimens.

Station 101: Five specimens.

Antigua; English Harbour; rocks.-Seven small specimens.

Antigua; English Harbour.-Seven specimens.

Antigua; Falmouth Harbour.-One specimen which in life was "deep reddish brown."

No label.-One specimen.

\section{Ophiopsila hartmeyeri Kohler}

Station 53: One specimen.

Station 96: One specimen.

\section{Family Ophiodermatidæ}

Ophioderma appressa (Say)

Station 11: One small specimen.

Barbados; Pelican Island; tide pools; May 11, 1918.-Two specimens.

Barbados; Pelican Island.-Ten specimens.

Barbados; off Needham's Point; June 6, 1918.-Four specimens.

Station 101: Three specimens.

Station 103: Five specimens.

Station 104: Two specimens.

Antigua; Englisl Harbour; in eel grass.-Sixteen specimens.

Antigua; English Harbour.-Sixteen specimens.

Antigua; Falmouth Harbour; in eel grass; collected by W. K. Fisher.-Eighteen specimens.

\section{Ophioderma brevicauda (Say)}

Barbados; Pelican Island; tide pools.-Six specimens.

Barbados; Pelican Island.--Seventeen specimens.

Barbados; off Needham's Point; June 8, 1918.-One specimen. Antigua; English Harbour.--Nine specimens. 
Ophioderma cinerea (Lyman)

Station 78: One specimen.

Antigua; English Harbour.-Five specimens.

Ophioderma rubicunda Lyman

Station 98: One specimen.

Pelican Island: One specimen.

Station 101: Three specimens.

\section{Family Ophiolepididæe}

\section{Ophiura acervata Lyman}

Station 116: One specimen.

Ophiomusium testudo Lyman

Station 2: One small specimen.

Station 11: One small specimen.

Station 26: Two small specimens.

Station 51: Three small specimens, kindly determined for me by Dr. H. L. Clark.

Station 79: One small specimen.

Ophiomusium validum Ljungman

Station 116: One specimen.

Ophiomusium sculptum Verrill

Station 4: Three specimens.

Station 7: One specimen; "arms banded with orange on whitish."

Station 15: One specimen.

Station 28: One specimen.

Station 44: One specimen.

Station 49: One specimen.

Ophiozona impressa (Lütken)

Station 51: One small specimen.

Ophiozonella nivea (Lyman)

Station 1: One specimen.

Station 3: One specimen.

Station 26: One specimen.

Ophiozonella tessellata (Lyman)

Station 62: One specimen. 
Ophiolepis elegans Lütken

Station 11: One specimen.

Station 18: One specimen.

?Barbados.-Three specimens.

Antigua; English Harbour.-Eleven specimens.

Ophiolepis paucispina Müller and Troschel

Station 1: One specimen.

Antigua; English Harbour; in eel grass.-Thirteen specimens.

LIST OF THE STATIONS, WITH THE SPECIES REPRESENTED AT EACH

The Crinoids collected at these Stations are also given.

Station 1:

Amphiura diducta

Amphiodia planispina

Ophionereis reticulata

Ophiactis savignyi

Ophiocoma riisei

Ophiothrix angulata

Ophiozonella nivea

Ophiolepis paucispina

Station 2 :

Hemieuryale pustulata

Ophiomusium testudo

Station 3:

$$
\text { Leptonemaster venustus }
$$

Station 4:

Ophiomusium sculptum

Station 7 :

Astroschema oligactes Ophiomusium sculptum

Asteroporpa annulata

Leptonemaster venustus

Democrinus rawsonii

Station 9:

Ophiacantha mesembria

Comactinia meridionalis

Station 11:

Ophiactis mülleri

Ophiothrix angulata

Ophioderma appressa

Ophiomusium testudo

Ophiolepis elegans

Leptonemaster venustus

Comactinia meridionalis

Station 13:

Ophiothrix angulata

Analcidometra armata

Leptonemaster venustus 
Station 14:

Station 15:

\section{Comactinia meridionalis}

Ophiacantha mesembria Ophiomusium sculptum

Coccometra hagenii

Station 18:

Ophiothrix angulata Ophiolepis elegans

Station 26:

Leptonemaster venustus

Ophiosciasma gramulatum Ophiomusium testudo

Station 28:

Ophiacantha mesembria Ophiomusium sculptum

Station 34:

Station 35 :

$$
\text { Astroschema oligactes }
$$

Astroschema oligactes

Station 36:

Astroschema love

Hemieuryale pustulata

Station 37:

Station 41:

$$
\text { Ophiacantha mesembria }
$$

Station 44:

$$
\text { Asteroporpa anmulata }
$$

Station 46 :

$$
\text { Ophiomusium sculptum }
$$

Astroschema arenosum

Leptonemaster venustus

Station 49 :

Station 50:

$$
\text { Ophiomusium sculptum }
$$

Nemaster discoidea

Station 51:

Hemieuryale pustulata Ophiozona impressa

Ophiothrix angulata Nemaster discoidea

Ophiomusium testudo

Comactinia meridionalis

Station 53:

Ophiothrix suensonii

Nemaster iowensis

Station 55: 
Station 56:

$$
\text { Leptonemaster venustus }
$$

Station 57:

$$
\text { Hemieuryale pustulata }
$$

Station 58:

$$
\text { Asteroporpa anmulata }
$$

Station 59:

Astroschema tenue

Ophiacantha mesembria

Station 62:

Ophiothrix suensonii
Ophiothrix suensonii

Leptonemaster venustus

Station 64:

Station 65:

$$
\text { Hemieuryale pustulata }
$$

Ophiozonella tessellata

Station 67:

$$
\text { ophiothrix angulata }
$$

ophiactis mülleri

ophiothrix angulata

Station 70 :

Hemieuryale pustulata

Ophionereis reticulata
Leptonemaster venustus

Comactinia meridionalis

Station 78:

Ophiothrix angulata

Ophioderma cinerea

Station 79 :

Amphipholis limbata

Ophionereis reticulata
Leptonemaster venustus

Comactinia meridionalis

Station 82 :

Ophiomusium testudo

Nemaster discoidea

Hemieuryale pustulata

Station 85:

Ophiothrix angulata

Comactinia meridionalis

Station 89 :

Ophiothrix suensonii

Station 92 :

Nemaster discoidea 
Station 96:

Ophiothrix angulata

Ophiocoma echinata

Ophiocoma pumila

Ophiocoma riisei

Comactinia meridionalis

Station 97:

Astrocyclus cacilia

Sigsbeia murrhina

Nemaster iowensis

Station 98 :

Nemaster iowensis

Station 99:

Nemaster iowensis

Station 100:

Ophiothrix angulata

Ophiocoma riisei

Barbados; Engineers' Pier, 15-20 feet

Ophiothrix angulata

Ophiothrix oerstedii

Ophiothrix suensonii

Barbados; Engineers' Pier, 25 feet

Nemaster iowensis

Barbados; Pelican Island, tide pools

Ophiomyxa flaccida

Ophiocoma echinata
Ophiocoma pumila

Ophioderma appressa

Barbados; off Pelican Island, 4 fathoms

ophiothrix angulata

Ophiothrix lineata

Ophiothrix suensonii

Barbados; off Pelican Island, 50 feet

Ophiothrix angulata

Barbados; off Pelican Island

Ophiothrix suensonii

Ophiocoma pumila

Ophioderma appressa

Ophioderma brevicauda

Barbados; Carlisle Bay, 5 fathoms

Astrophytum muricatum

Barbados; Carlisle Bay, 20 feet

Astrophytum muricatum

Ophiothrix suensonii 
Barbados; off Needham's Point

Ophiothrix angulata

Ophiocoma pumila

Ophiothrix oerstedii

Ophioderma appressa

Ophiothrix suensonii

Ophioderma brevicauda

Barbados; off Hastings

Ophiothrix suensonii

Barbados ; Bathsheba

Ophiocoma echinata

Barbados; from fish pots

Astrophytum muricatum

Barbados

Sigsbeia murrhina

Nemaster discoidea

Nemaster iowensis

Comactinia meridionalis

?Barbados

Station 101:

Ophiolepis elegans

Ophiactis mïlleri

Ophiothrix angulata

Ophiothrix suensonii

Ophionereis reticulata

Ophiocoma echinata

Ophiocoma riisei

Ophioderma appressa

Ophioderma rubicunda

Nemaster iowensis

Station 103:

Ophioderma appressa

Station 104:

\section{Ophioderma appressa}

Station 116 :

Ophiura acervata

Ophiomusium validum

Antigua; English Harbour, in eel grass
Ophiothrix angulata
Ophiocoma echinata
Ophiothrix oerstedii
Ophioderma appressa
Ophiolepis paucispina

Antigua; English Harbour, rocks

Ophiothrix oerstedii

Ophiocoma pumila

ophiocoma echinata

ophiocoma riisei 
Antigua; English Harbour

Ophiomyxa flaccida

Ophiothrix suensonii

Ophionereis reticulata

Ophiocoma echinata

Ophiocoma pumila

Antigua; Falmouth Harbour

Ophiocoma pumila
Ophiocoma riisei

Ophioderma appressa

Ophioderma brevicauda

Ophioderma cinerea

ophiolepis elegans

Antigua

Ophioderma appressa

Ophiocoma echinata 



\title{
REPORT ON THE BRACHYURA
}

Collected by the Barbados-Antigua Expedition from the University of Iowa in 1918

\author{
Mary J. Rathbun
}

Associate in Zoology, U. S. National Museum

\section{INTRODUCTION}

Hughes in his "Natural History of Barbados", 1750,1 enumerates fifteen kinds of crabs, but the descriptions are so brief and the names so trivial that it is impossible to determine most of the species with any great degree of certainty. Only two of the brachyuran erabs are figured; one, the Horned Crab (pl. $\mathrm{XXV}$, fig. 3 ) is an undoubted Stenocionops furcata, the other, the Lazy Crab, (pl. XXV, fig. 1) is a composite, having the chelipeds and ambulatory legs of Mithrax spinosissimus attached to the body of a Parthenopid crab, Daldorfia horrida (= Parthenope horrida of authors), an Indo-Pacific species.

From the dredgings of the U. S. Coast Survey steamers "Blake" and "Hassler", A. Milne Edwards" in 1880 published a list which includes thirty-eight species of brachyuran crabs from the waters about Barbados. This is supplemented by the later report (1902) on the Oxystomes of the same collection by Milne Edwards and Bouvier, ${ }^{1}$ which adds three species to the earlier list.

The present expedition obtained ninety-three species of brachyurans of which only one species is found to be undescribed. The range of twenty-nine spceies is extended by their capture at Barbados.

\section{LIST OF SPECIES \\ Tribe Brachyura \\ Subtribe Oxystomata \\ Family Dromiidæe}

Dromia ERYTHRopus (George Edwards)

Rathbun, Ann. Inst. Jamaica, vol. I, 1897, p. 39.

1 See bibliography on page 89 . 
Carlisle Bay, Barbados; in fish pot; 1 \&.

Brought up by diver off Pelican Island, Barbados; 1 ovigerous.

Dromidia antillensis Stimpson

Rathbun, Ann. Inst. Jamaica, vol. I, 1897, p. 39.

Barbados; 1 \& ovigerous.

\section{Family Dorippidæ}

Cyclodorippe PERPusilla (Rathbun)

Clythrocerus perpusillus Rathbun, Bull. U. S. F. C., vol. XX for 1900, part 2, 1901, p. 90, text-fig. 4 .

One mile S. W. of Pelican Island, Barbados; 38 fathoms; bottom of fine coral fragments; May 13 ; sta. 1; 1 \%, the same size as the type.

Known only from the type specimen, off Vieques.

\section{Family Raninidæ}

RaninoIdes LeEvis (Latreille)

Ranina loevis Latreille, Encyc. Métl., Entom., vol. X, 1825, p. 268.

Raninoides levis Milne Edwards, Hist. Nat. Crust., vol. II, 1837, p. 197.

Barbados; W. by N. of Pelican Island 23/4 miles and drifting off shore; 107 fathoms; bottom of fine sand; tangles; May 16; sta. $10 ; 1$ small t, 1 young.

In the young specimen, earapace $6 \mathrm{~mm}$. long, the supra-orbital margin between the two fissures is not produced in a spine but is obliquely truncate.

\section{Family Calappidæ}

\section{Calappa angusta A. Milne Edwards}

Bull. M. C. Z., vol. VIII, 1880, p. 18.

Barbados; Lazaretto E. by N. 1/2 N., Pelican Island S. E.; bottom of fine sand; June 7; sta. $88 ; 1$ juv.

Taken at Barbados by the "Hassler," 100 fathoms, and by the "Blake," 103 fathoms.

\section{Calappa gallus (Herbst)}

Rathbun, Bull. U. S. F. C., vol. XX for 1900, part 2, 1901, p. 85.

Pelican Island, Barbados; in fish pot; 1 . 
Cycloes bairdi Stimpson

Rathbun, Bull. U. S. F. C., vol. XX for 1900, part 2, 1901, p. 85 .

English Harbour, Antigua; 1 \& $10.4 \mathrm{~mm}$. long.

One mile S. W. of Pelican Island, Barbados; 38 fathoms; bottom of fine coral fragments; May 13 ; sta. $1 ; 1$ juv.

In the West Indies, this species seems not to have been reported south of Guadeloupe; although it occurs in the Pacific at Panama.

\section{Family Leucosiidæe}

\section{Ebalia stimpsonil A. Milne Edwards}

Rathbun, Bull. U. S. F. C., vol. XX for 1900, part 2, 1901, p. 87.

Barbados; Cable Station E. S. by E., Paynes Bay Church N. E., off shore $3 / 4$ mile; $35-75$ fathoms; bottom alternate sand and rocks; sta. $78 ; 1$ t.

Described from off Barbados, 7 to 50 fathoms, "Blake."

Iliacantha subglobosa Stimpson

Bull. M. C. Z., vol. II, 1871, p. 155.

W. by N. of Pelican Island, Barbados, 2 miles; $75-80$ fathoms; sand bottom; sta. $3 ; 1$ \& juv.

S. of St. Mathias Church, Barbados, 1 mile; 60 fathoms; bottom of coarse sand; May 20; sta. 21; 1 t.

W. by $N$. of Telegraph Station, Barbados, $1 / 2$ mile or more off shore, about edge of drop off; 50-70 fathoms; bottom rocky; tangles; June 1; sta. 66 and $67 ; 2$ \% juv.

Dredged by the "Blake" at Barbados, 56 to 94 fathoms.

\section{Subtribe Brachygnatha}

Superfamily Brachyrhyncha

\section{Family Portunida}

Portunus (Portunus) sulcatus (A. Milne Edwards)

Rathbun, Bull. U. S. F. C., vol. XX for 1900, part 2, 1901, p. 45.

English Harbour, Antigua; by electric light; July ; 1 juv., 3.2 mm. long.

Bathsheba, Barbados; 1 t juv.

Pelican Island, Barbados; tide pool; May 13; 1 t juv. 


\section{Portunus (Achelous) ordwayi (Stimpson)}

Rathbun, Bull. U. S. F. C., vol. XX for 1900, part 2, 1901, p. 46 .

English Harbour, Antigua; electric light; July, 1918; 1 juv. Callinectes ornatus Ordway

Rathbun, Bull. U. S. F. C., vol. XX for 1900, part 2, 1901, p. 48.

Barbados; 1 adult $\$$.

Cronius RUBER (Lamarck)

Charybdella rubra Rathbun, Bull. U. S. F. C., vol. XX for 1900, part 2, 1901, p. 51 .

Antigua; 1 juv.

\section{Family Xanthidæ}

Liomera longimana A. Milne Edwards

Rathbun, Bull. U. S. F. C., vol. XX for 1900, part 2, 1901, p. 25.

Barbados; May $15 ; 10$ t 9 \% ovig. On old coral; May 31 ; 8 ᄒ 15 ९. On old coral heads; June $4 ; 12$ ᄒ 11 \% (1 ovig.). Needham Point, Barbados; May 18; 3 t 1 \%.

One mile S. of sta. 19, off Needham Point; 84 fathoms; rocky bottom; sta. $20 ; 2$ t 4 \% .

Okra Reef, Barbados; May 13; 35 t 44 ९ (35 ovig.) 8 juv. Not previously noted south of Guadeloupe.

\section{Liomera dispar (Stimpson)}

Rathbun, Bull. U. S. F. C., vol. XX for 1900, part 2, 1901, p. 25.

Pillars of Hercules, Antigua; 1 .

Barbados; May 15; 6 t 21 \% (8 ovig.). On old coral, May 31 ; 3 む 13 ९ 2 juv. On old coral heads; June $4 ; 4$ t 4 \%.

One mile S. of sta. 19, off Needham Point, Barbados; 84 fathoms; rocky bottom; sta. $20 ; 2$ t 4 q (2 ovig.).

Okra Reef, Barbados; May 13; 3 t 14 q (7 ovig.).

Not previously recorded south of Porto Rico.

Platypodia spectabilis (Herbst)

Rathbun, Bull. U. S. F. C., vol. XX for 1900, part 2, 1901, p. 26.

Needham's Point, Barbados; May 18; 1 t 1 \& ovig. 


\section{Leptodius Floridanus (Gibbes)}

Rathbun, Bull. U. S. F. C., vol. XX for 1900, part 2, 1901, p. 27.

Pillars of Hercules, Antigua; 1 .

Barbados; 8 t 3 \% ovig.

Pelican Island, Barbados; tide pools; 2 t. May 11; 3 б. May $13 ; 4$ \& (3 ovig.). Shallow; 1 t 1 \& juv.

Okra Reef, Barbados; May 13; 1 juv.

\section{Xanthodius parvulus (Fabricius)}

Rathbun, Bull. U. S. F. C., vol. XX for 1900, part 2, 1901, p. 27 .

Pelican Island, Barbados; shallow; 2 б. In tide pool; May $11 ; 1$ t juv. 1 ․

Barbados; 1 †.

No label; 1 t.

\section{Cycloxanthops denticulatus (White)}

Rathbun, Bull. U. S. F. C., vol. XX for 1900, part 2, 1901, p. 27.

Pillars of Hercules, Antigua; 1 t juv.

Pelican Island, Barbados; tide pool; 1 む.

Bathsheba, Barbados; 2 juv.

\section{Panopeus herbstil Milne Edwards}

Eupanopeus herbstii Rathbun, Bull. U. S. F. C., vol. $\mathrm{XX}$ for 1900, part 2, 1901, p. 28.

English Harbour, Antigua ; 1 t juv.

Pillars of Hercules, Antigua; 1 t thin shell, 2 juv.

Barbados; 2 ᄒ 1 \%.

\section{Panopeus occidentalis Saussure}

Eupanopeus occidentalis Rathbun, Bull. U. S. F. C., vol. XX for 1900, part 2, 1901, p. 29.

Pillars of Hercules, Antigua; 1 \&.

\section{Panopeus americanus Saussure}

Eupanopeus americanus Rathbun, Bull. U. S. F. C., vol. XX for 1900, part 2, 1901, p. 29.

Pillars of Hereules, Antigua; 1 t small. 


\section{Panopeus hartti Smith}

Eupanopeus harttii Rathbun, Bull. U. S. F. C., vol. XX for 1900, part 2, 1901, p. 29.

Pillars of Hercules, Antigua; 1 .

Pelican Island, Barbados; shallow; 1 .

Eurypanopeus abBreviatus (Stimpson)

Rathbun, Bull. U. S. F. C., vol. XX for 1900, part 2, 1901, p. 30 .

Pillars of Hercules, Antigua; 1 t 1 \& 1 juv.

Hexapanopeus hemphilli (Benedict and Rathbun)

Rathbun, Bull. U. S. F. C., vol. XX for 1900, part 2, 1901, p. 31 .

Barbados; from old coral head; June 4; 1 of medium size, identified with some doubt, as both sides of the body are infested with an isopod parasite which has so distorted the carapace that the lateral teeth are abnormal and unlike on the two sides.

Not before found south of St. Thomas and Porto Rico.

\section{Micropanope lobifrons A. Milne Edwards}

Rathbun, Bull. U. S. F. C., vol. XX for 1900, part 2, 1901, p. 32 .

S. W. of Pelican Island, Barbados, 1 mile; 38 fathoms; bottom of fine coral fragments; May 13; sta. 1; 2 t 2 \%.

One-half mile W. of sta. $17 ; 40$ fathoms; bottom coarse sand; Nay 18 ; sta. $18 ; 1$ \&.

W. N. W. of Lazaretto, Barbados; N. N. W. of Pelican Island; 33 fathoms; bottom rocky; dredge; May 27; sta. $51 ; 9$ \& (1 ovig., 3 with Rhizocephalids).

Cable station, Barbados, bears E. by S., Lazaretto, E. S. E. 1/2 S.; 35-60 fathoms; bottom mostly rocky, on steep slope; tangles; June 3 ; sta. $75 ; 1$ t.

Cable station E. S. by E., Paynes Bay Church N. E., off shore $3 / 4$ mile; 35-75 fathoms; bottom alternate sand and rocks; June 3 ; sta. $78 ; 1$ \& with a small Rhizocephalid under the abdomen.

W. by N. of Telegraph Station, Barbados; little more than a half mile off; 30-65 fathoms; bottom of rocks and sand; June 5; sta. $79 ; 3$ \& ( 2 with a Rhizocephalid larger than the abdomen but attached under it).

Taken at Barbados by the "Blake" in 94 fathoms. 
Actaea rufopunctata nodosa Stimpson

Rathbun, Bull. U. S. F. C., vol. XX for 1900, part 2, 1901, p. 33 .

$11 / 4$ miles due $W$. from white lighthouse at Needham Point, Barbados; in line with red house; $67-70$ fathoms; bottom stony; May 17 ; sta. $11 ; 1$ t juv.

Taken at Barbados by the "Blake" in 94 fathoms.

Actaea setigera (Milne Edwards)

Rathbun, Bull. U. S. F. C., vol. XX for 1900, part 2, 1901, p. 34 .

Pillars of Hercules, English Harbour, Antigua; 2 б.

English Harbour, Antigua; 1 t 1 juv.

Okra Reef, Barbados; May 13; 1 t 3 juv.

Pelican Island, Barbados; 1 \% juv.

Needham Point, Barbados; 1 t juv. Nay 18; 1 $q$ juv.

Barbados; 1 t. May $15 ; 1$ t 4 juv. From old coral head; May $31 ; 1$ q juv., 1 juv. From coral heads; June $4 ; 1$ t 1 \% juv.

Not before recorded from so far south.

Actaea bifrons Rathbun

Bull. U. S. F. C., vol. XX for 1900, part 2, 1901, p. 34.

Barbados; 1 t.

Shoal Bank, Barbados; 30 fathoms; bottom rough; June 12; sta. $96 ; 1$ t.

Shoal Bank, about 3 miles W. of Needham Point; $20-40$ fathoms; sponge bottom; sta. $101 ; 1$ む.

This species has been found only off Porto Rico and Colon.

Xanthias nutting Rathbun

Bull. U. S. F. C., vol. XX for 1900, part 2, 1901, p. 35.

Barbados; 1 small t.

\section{Xanthiam gRanulimanus (Stimpson)}

Plate II, figs. 2 and 3.

Rathbun, Bull. Lab. Nat. Hist. State Univ. Iowa, vol. IV, 1898, p. 271.

Barbados; from coral heads; June 4; 1 ᄋ ovigerous.

Known previously from Bahamas and Cuba. 
Carapace suboval, front slightly advanced, regions indicated by shallow furrows; anterior and antero-lateral regions irregularly granulated, the coarser granules forming short lines near the lateral teeth. Edge of front bow-shaped, a short median slit. Upper margin of orbit transverse and a little sinuous. Four antero-lateral teeth beside the angle of the orbit, first tooth low, remote from orbit, remaining teeth sharp-pointed, edge of orbit and teeth granulate. Lower surface of carapace densely granulate, lower margin of orbit more advanced than upper, with a $V$-shaped outer sinus and a thick, triangular tooth at inner angle.

Chelipeds unequal, exposed surfaces of carpus, manus and proximal ends of fingers coarsely granulate; fingers deeply grooved, the granules extending more than half the length of the interrening ridges in the smaller chela. Legs hairy, especially the last three segments, upper margin of merus and upper surfaces of carpus and propodus denticulate.

The above description was made from a Bahama specimen $(q)$ in the U. S. National Museum. The Barbados specimen is much smaller but ovigerous. Length of earapace $3.7 \mathrm{~mm}$., width $5.2 \mathrm{~mm}$.

Chlorodiella longimana (Milne Edwards)

Rathbun, Bull. U. S. F. C., vol. XX for 1900, part 2, 1901, p. 36 .

Barbados; May 15; 3 t 7 q (1 ovig.) 2 juv.

Coral heads; Nay $31 ; 1$. On old coral heads; June 4 ; 3 $\delta$ 2 \%.

Okra Reef, Barbados; May 13; 2 t 2 \%.

One mile S. of sta. 19, off Needham Point, Barbados; 84 fathoms; bottom rocky; sta. $20 ; 1$ t.

Not previously recorded from Barbados; known from Guadeloupe and Curaçao.

Ozius reticulatus (Desbonne and Schramm)

Rathbun, Bull. U. S. F. C., vol. XX for 1900, part 2, 1901, p. 37 .

Barbados; 1 \%.

Not previously recorded from Barbados; the nearest points are Guadeloupe and Puerto Colombia.

\section{Pilumnus caribaeus Desbonne}

In Desbonne and Schramm, Crust. Guadeloupe, 1867, p. 32. Needham Point, Barbados; May 18; 1 \&.

In this species the lateral spines are 4 , including the spine at the outer 
angle of the orbit; the first and often the second spine is bifid. In the Barbados specimen, there is a spine immediately following the orbital spine, which is subequal to it, and the second spine also is double, composed of 2 separate spines, the hinder of the two being smaller; in short, the margin appears to be 6 -spined. Two spines on the dorsal surface of the hepatic region and one on the branchial region near by, are larger than usual. The outer surface of the larger as well as of the smaller palm is rough all over.

Not previously known south of Guadeloupe.

Pilumnus barbadensis, sp. nov.

\section{Plate I}

Type-locality.-Barbados; from old coral heads; May 31; 3 t 2 \% the largest $t$ has been selected as the holotype. (Cat. No. -, Mus. Univ. Iowa.)

Additional lots.-Okra Reef, Barbados; May 13; 2 young. Barbados; from coral heads; June 4; 5 small.

Measurements. - Male holotype, length of carapace 6.7 , width $9.4 \mathrm{~mm}$. The largest $q$ is $12.3 \mathrm{~mm}$. wide and too broken to permit measurement of the length; figured $q$, length 7.6 , width $10.7 \mathrm{~mm}$.

Description.-Carapace suboval, antero-lateral margin arched but shorter than the postero-lateral margin. Surface covered with a short, soft, sparse pubescence which does not conceal the carapace. Furrows between regions and gastric subregions well marked. Surface minutely roughened, especially along the front and antero-lateral regions where the granules are acutely pointed. The lobes of the front are oblique, slightly convex save at outer end which is right angled; edge crenulate. Inner orbital angle acute, elevated; upper orbital margin sloping obliquely outward and backward to a slight outer tooth. Edge of orbit finely denticulate. Antero-lateral margin armed with 3 slender, acuminate spines, each set in a stout, triangular, denticulate base. The carapace is widest at the posterior pair of these spines; the two interspaces are subequal; between the anterior spine and the orbital angle there is a spinule, little larger than the sharp denticles of the neighboring surface, and confused in dorsal riew with several subhepatic spinules. Suborbital region covered with coarse, acute granules. Lower orbital region more advanced than upper, its spinules more elongate; spinule at inner angle a little larger and more pronounced.

Chelipeds rery unequal, thinly clothed with longer hairs than the earapace; carpus covered with acute granules, and with two spinules, one above the other at the inner angle. Only the proximal third or less of the major palm is rough with granules, the roughness forming an oblique band bordering the carpus but stopping short of the lower margin; the proximal two- 
thirds of the lower edge is separately roughened; remainder of palm smooth and naked; fingers of $t$ dark brown with light tips, color not reaching quite to base of immorable finger, color line vertical; a narrow interdigital gape. In the minor cheliped the entire outer surface of the palm is very rough, the granules arranged for the most part longitudinally; the fingers are less gaping and are deeply grooved, the ridges very rough.

In the female, the fingers are a lighter brown and in the largest female the roughness on the major palm is less extensive.

Ambulatory legs slender, bordered with long hair; merus slightly enlarged, upper margin edged with slender spines. Dactyli noticeably slender.

Relationships.-Of the Pilumnus in the West Indian fauna, this approaches nearest to $P$. spinipes (= Micropanope spinipes A. Milne Edwards ${ }^{1}$ ) in many details such as the ornamentation of the antero-lateral margin, the partial roughness of the major palm, the slender legs. On the other hand, the carapace of barbadensis is more oval and more convex, front more deflexed, and the minor palm rough all over, while in spinipes the granulation is similar on the two palms.

$P$. andrewsii Rathbun ${ }^{2}$ is a broad species with antero-lateral margin similar to that of barbadensis, but the interregional furrows are deeper, the upper orbital border has two small but distinct emarginations, the major palm is smooth, the minor one nearly so.

\section{Pilumnus floridanus Stimpson}

Rathbun, Bull. U. S. F. C., vol. XX for 1900, part 2, 1901, p. 40 .

W. N. W. of Lazaretto, N. N. W. of Pelican Island, Barbados; dredged in from 80-100 fathoms to where rocks begin at about 35 fathoms; bag full of coarse sand; sta. 53;1 $q$ ovig.

Not previously known south of Porto Rico and St. Thomas.

\section{Heteractaea ceratopus (Stimpson)}

Pilumnus ceratopus Stimpson, Ann. Lye. Nat. Hist. N. Y., vol. VII, 1860, p. 215.

Needham Point, Barbados; by diver; 1 \&.

Barbados; May 22; 1 juv. From coral heads; June 4; 1 б 4 ․

Not recorded south of Guadeloupe.

1 Crust. Rég. Mex. 1880, p. 326, pl. LIV, fig. 3.
2 Bull. Lab. Nat. Hist. State Univ. Iowa, Vol, IV, 1898, p. 266, pl. V, fig. 2. 


\section{Eriphia gonagra (Fabricius)}

Rathbun, Bull. U. S. F. C., vol. XX for 1900, part 2, 1901, p. 42.

Pillars of Hercules, English Harbour, Antigua; 1 juv.

Barbados; 1 ᄒ 3 \% (all small).

Bathsheba, Barbados; 3 t (the largest one with abnormal abdomen, which is intermediate in width between $\delta$ and adult ९).

Needham Point, Barbados; 3 \& (1 ovig.).

Pelican Island, Barbados; tide pool; May $11 ; 1$ \&, 1 juv.

No label; 3 t 4 ㅇ (3 ovig.).

\section{Melybia thalamita Stimpson}

Rathbun, Bull. U. S. F. C., vol. XX for 1900, part 2, 1901, p. 43.

Barbados; 2 t 1 워 ovig. From broken coral; May $27 ; 1$ 의 ovig.

S. W. of Pelican Island, Barbados, 1 mile; 38 fathoms; bottom of fine coral fragments ; May 13; sta. 1; 1 \% ovig., 2 juv.

Not previously recorded from Barbados; found at Porto Rico and Colon.

Domecia hispida Eydoux and Souleyet

Rathbun, Bull. U. S. F. C., vol. XX for 1900, part 2, 1901, p. 43.

Barbados; May $15 ; 1$ o ovig. May $22 ; 1$ juv. In coral heads; Nay $31 ; 1$ ․ From coral heads; June $4 ; 1$ t. Living in Acropora; 1 t 3 क ovig. 1 young.

Okra Reef, Barbados; May 13; 1 t 6 क (4 ovig.).

Needham Point, Barbados; May 18; 1 t.

One mile S. of sta. 19, off Needham Point; 84 fathoms; bottom rocky; sta. $20 ; 1$ t 4 \& (2 ovig.).

W. by N. of Pelican Island, 11/2 miles; 80 fathoms; bottom rocky; tangles without weight; May 16; sta. 7 ; 1 young.

\section{Family Goneplacidæ}

Goneplax barbata (A. Milne Edwards)

Rathbun, Bull. U. S. N. M., No. XCVII, 1918, p. 26, pl. IV, figs. 1 and 3 ; pl. V. 
W. by N. of Pelican Island, Barbados, 2 miles; $75-80$ fathoms; sand bottom; May 15; sta. 3; 1 \% immature.

This specimen unites the characters of $G$. barbata ${ }^{1}$ and $G$. sigsbei, ${ }^{2}$ as given in my monograph (pp. 26-27). It will be noted there that all the specimens (4) of barbata recorded are male, while both those of sigsbei are female. The specimen in hand has the lateral dentation of barbata, as shown in plate $\mathrm{V}$, while lacking a branchial ridge, an orbital notch, and a patch of hair on the eheliped, which three characters link it to sigsbei. There is a very small but sharp spine on the upper margin of the arm and the inner angle of the wrist, not the prominent, eurved spine of typical barbata, nor the blunt tooth of sigsbei.

Both barbata and sigsbei are recorded from off Grenada, and barbata also from Gulf of Mexico and Straits of Florida.

\section{Panoplax nepressa Stimpson}

Rathbun, Bull. U. S. Nat. Mus., No. XCVII, 1918, p. 47, pl. XII, figs. 1 and 2, text-fig. 21.

Barbados; 1 t 1 ․ From broken coral; May 27; 1 t.

Not previously noted south of Porto Rico.

\section{Family Pinnotheridæ}

\section{Parapinnixa hendersoni Rathbun}

Bull. U. S. Nat. Mus., No. XCVII, p. 109, 1918, pl. XXVI, figs. 1-5.

English Harbour, Antigua; by electric light; July; 1 t 2 \%.

This extends the range of the species, which heretofore has been found in N. W. Cuba and on the west coast of Florida.

\section{Family Cymopoliidæe}

Crmopolia affinis (A. Milne Edwards and Bouvier)

Rathbun, Bull. U. S. Nat. Mus., No. XCVII, 1918, p. 196, pl. XLVI, pl. XLVII, fig. 3, text-fig. 121.

S. W. of Pelican Island, Barbados, 1 mile; 38 fathoms; bottom of fine coral fragments; May 13; sta. 1; 1 t 1 \%, both immature.

Previously taken off Barbados in 68 fathoms by the U. S. C. S. Str. "Blake."

\footnotetext{
1 Rathbun, Bull. U. S. Nat. Mus., No. XCVII, 1918, p. 26, pl. IV, figs. 1 and 3 , pl. V.

2 Op. cit., p. 26, pl. IV, figs, 2 and 4.
} 


\section{Crmopolia bahamensis (Rathbun)}

Rathbun, Bull. U. S. Nat. Mus., No. XCVII, 1918, p. 200, pl. XLVII, figs. 1 and 2.

Barbados; Lazaretto bears S. E. by E., 1/2 mile off shore; 35 fathoms; bottom rocky; tangles; May 24 ; sta. 42 ; 1 앙.

Known only from the Bahamas.

\section{Cramopolia sica A. Milne Edwards}

Rathbun, Bull. U. S. Nat. Mus., No. XCVII, 1918, p. 208, pl. XL, figs. 3 and 4, text-fig. 127.

11/4 miles W. of Telegraph Station, Barbados; 118 fathoms; bottom of fine sand; May 30 ; sta. $60 ; 1$ \& ovig.

Taken by the "Blake" off Barbados in 82 fathoms.

\section{Family Grapsidæ}

\section{Grapsus grapsus (Linnaeus)}

Rathbun, Bull. U. S. Nat. Mus., No. XCVII, 1918, p. 227, pls. LIII and LIV, text-fig. 135.

Barbados; 3 t 4 \% (2 ovig.).

\section{Geograpsus lividus (Milne Edwards)}

Rathbun, Bull. U. S. Nat. Mus., No. XCVII, 1918, p. 232, pl. LV.

Pelican Island, Barbados; May 18; 1 $q$; nocturnal; color in life, light olive brown, marbled on earapace with dark Van Dyke brown; legs faintly spotted.

Goniopsis cruentata (Latreille)

Rathbun, Bull. U. S. Nat. Mus., No. XCVII, 1918, p. 237, pl. LVII, text-fig. 136.

Bridgetown, Barbados; mangrove swamp; 2 † 1 \% 1 t is shedding.

N. of Bridgetown, mangrove swamp; 1 .

\section{Pachygrapsus transversus (Gibbes)}

Rathbun, Bull. U. S. Nat. Mus., No. XCVII, 1918, p. 244, pl. LVI, figs. 2 and 3.

Pillars of Hercules, Antigua ; 4 t 4 q (3 ovig.).

English Harbour, Antigua; 1 t 1 ㅇ ovig. 
Bathsheba, Barbados; 1 t.

Needham Point, Barbados; 1 .

Barbados; 1 \& ovig.

Euchirograpsus americanus A. Milne Edwards

Rathbun, Bull. U. S. Nat. Mus., No. XCVII, 1918, p. 282, pl. LXXIV, text-fig. 144.

W. of Telegraph Station, Barbados, 1 mile; 86 fathoms; bottom rocky; May 30 ; sta. $59 ; 1$ t.

Cable station, Barbados, bears E. by S., Lazaretto E. S. E. $1 / 2$ S.; 35-60 fathoms; bottom mostly rocky, working on steep slope; tangles; June 3 ; sta. $75 ; 1$ \& 1 juv.

The type-locality is off Barbados, 69 fathoms, "Blake."

Aratus pisonil (Milne Edwards)

Rathbun, Bull. U. S. Nat. Mus., No. XCVII, 1918, p. 323, pl. XCVI.

English Harbour, Antigua; 1 .

Pillars of Hercules, Antigua; 2 \& (1 ovig.).

\section{Plagusia depressa (Fabricius)}

Rathbun, Bull. U. S. Nat. Mus., No. XCVII, 1918, p. 332, pl. C1, text-fig. 154 .

Barbados; 1 old male.

Bathsheba, Barbados; 1 small but mature $q$.

Percnon gibbesi (Milne Edwards)

Rathbun, Bull. U. S. Nat. Mus., No. XCVII, 1918, p. 337, pl. CV.

Pillars of Hercules, Antigua ; 2 t 3 ( 1 juv.).

English Harbour, Antigua ; 2 juv.

Okra Reef, Barbados; May 13; 1 t juv.

\section{Family Gecarcinidæ}

\section{Cardisoma guanhumi Latreille}

Rathbun, Bull. U. S. Nat. Mus., No. XCVII, 1918, p. 341, pls. CVI and CVII, text-fig. 155.

Bridgetown, Barbados; 1 large, well-developed $t, 1$ adult $q$. Mangrove swamp, north of Bridgetown; 1 young $q$. 
UCIDES CORDatus (Linnaeus)

Rathbun, Bull. U. S. Nat. Mus., No. XCVII, 1918, p. 347, pls. CX-CXIII, pl. CLIX, figs. 3 and 4, text-fig. 158.

Barbados; 1 o small.

Antigua; mangrove swamp; 2 large $t$. The larger has a carapace $73.7 \mathrm{~mm}$. long, $100 \mathrm{~mm}$. wide. The greatest width compared to the length is intermediate between that given in my monograph for a smaller specimen of cordatus and the width of occidentalis.

This Antigua specimen lacks the first ambulatory leg on the right side; the first leg on the left side is shorter than the second leg, but may not be normal.

The smaller specimen of the two has the ambulatory legs of the right side normal; the first leg on the left side is no longer than, indeed, a trifle shorter than the second leg.

Both these specimens have the palm straighter below than in the specimens previously described by me. In spite of these variations in cordatus, there is no likelihood of confusion with occidentalis, as the palms of the latter are longer and slenderer than any of the cordatus examined, and the carapace is narrower behind in proportion to its greatest width.

Gecarcinus lateralis (Freminville)

Rathbun, Bull. U. S. Nat. Mus., No. XCVII, 1918, p. 355, pls. CXIX and CXX, text-fig. 161.

Barbados; 1 t 1 \& 1 juv.

\section{Family Ocypodidx}

OCypode albicans Bose

Rathbun, Bull. U. S. Nat. Mus., No. XCVII, 1918, p. 367, pls. CXXVII and CXXVIII.

Barbados; beach on south coast; 2 t.

Pelican Island, Barbados; 1 \&.

\section{UCA MORDAX (Smith)}

Rathbun, Bull. U. S. Nat. Mus., No. XCVII, 1918, p. 391, pl. CXXXIV, figs. 3 and 4, text-fig. 166.

English Harbour, Antigua; 2 t. In mangrove swamp; 1 , large. 
N. of Bridgetown, Barbados; mangrove swamp; 7 t 6 \&, of medium size.

\section{Superfamily Oxyrhyncha}

\section{Family Parthenopidæ}

Parthenope (Platylambrus) fraterculus (Stimpson)

Lambrus fraterculus Stimpson, Bull. M. C. Z., vol. II, 1871, p. 130.

Off Lazaretto, Barbados; 20 fathoms; bottom rough; tangles; June 6 ; sta. $87 ; 1$ t.

This specimen has the dorsal projections more acute than customary, and the chelipeds a little longer, with sharper teeth or spines.

Not before known from the West Indies. Its southern boundary has been Yucatan in the west, Miami in the east.

Solenolambrus tenellus Stimpson

Bull. M. C. Z., vol. II, 1871, p. 134.

Barbados; Lazaretto bear's S. E. by E., 1/2 mile off shore; 35 fathoms; bottom rocky; tangles; May 24 ; sta. $42 ; 1$ \& ovig.

Dredged off Barbados by the "Hassler," 100 fathoms, and by the "Blake" in 56 to 103 fathoms.

\section{Family Inachidæ}

\section{Subfamily Inachinæ}

Stenorynchus sagittarius (Fabricius)

Rathbun, Bull. U. S. F. C., vol. XX for 1900, part 2, 1901, p. 53 .

N. W. $1 / 2$ N. of Pelican Island, Barbados, W. $1 / 2$ S. of Lazaretto; 80 fathoms; bottom fine sand; May 27; sta. 49 ; 1 t.

Shoal Bank, Barbados, about 3 miles W. of Needham Point; 20-40 fathoms; sponge bottom; sta. $101 ; 1$ t.

Taken at Barbados by the "Blake" in 94 fathoms.

\section{PoDochela hípoglypha (Stimpson)}

Podonema hypoglypha Stimpson, Bull. II. C. Z., vol. II, 1871, p. 127.

Barbados; Paynes Bay Church bears E. N. E. and the Laza- 
retto S. E. by S., off shore $1 / 2$ mile; 50 fathoms; bottom rocky; tangles; May 31 ; sta. 64 ; 1 small but adult male.

Not before noted south of Guadeloupe.

Podochela gracilipes Stimpson

Bull. M. C. Z., vol. II, 1871, p. 126.

Lazaretto, Barbados, bears S. E. by E., 1/2 mile off shore; 35 fathoms; bottom rocky; tangles; May 24 ; sta. $42 ; 1$ t.

Cable station, Barbados, bears E. by S., Lazaretto E. S. E. 1/2 S.; 35-60 fathoms; bottom mostly rocky, working on steep slope; tangles; June 3 ; sta. $75 ; 1$ t.

Not before found in the lesser Antilles, although off Yucatan and Colombia.

\section{Batrachonotus fragosus Stimpsol}

Bull. M. C. Z., vol. II, 1871, p. 122.

S. W. of Pelican Island, Barbados, 1 mile; 38 fathoms; bottom of fine coral fragments; May 13 ; sta. 1; 1 t.

Euprognatha Gracilipes A. Milne Edwards

Rathbun, Bull. U. S. F. C., vol. XX for 1900, part 2, 1901, p. 58 .

2 miles due W. of Pelican Island, Barbados; 80 fathoms; bottom coarse sand; May 17; sta. 13; 1 small $t$.

Dredged by the "Blake" at Barbados in 69 to 76 fathoms.

Arachnopsis filipes Stimpson

Bull. II. C. Z., vol. II, 1871, p. 121.

Barbados; W. N. W. of Lazaretto; N. N. W. of Pelican Island; 33 fathoms; bottom rocky; dredge; May 27; sta. $51 ; 1$ ․

\section{Subfamily Pisinæ}

\section{Chorinus heros (Herbst)}

Rathbun, Bull. U. S. F. C., vol. XX for 1900, part 2, 1901, p. 61 .

Pelican Island, Barbados; tide pool; May 11; 1 immature.

\section{Herbstia depressa Stimpson}

Plate II, fig. 4.

Ann. Lyc. Nat. Hist. N. Y., vol. VII, 1860, p. 57. 
Barbados ; May 15; 1 q ovig.; median length of carapace 14, width 12 , length to tip of rostral horns $14.8 \mathrm{~mm}$.

Besides the tubercles on the carapace mentioned by Stimpson there are 4 tubercles or granules forming a transverse oblong on the branchial region, 2 of the granules near the inner angle of this region and the other 2 granules in a line posterior to the middle of the cardiac region. There is also a granule on the dorsal surface which forms a triangle with the 2 marginal spines at the widest part of the carapace. The row of spines on the merus of the cheliped is on its upper margin.

Not before found south of St. Thomas.

Lissa bicarinata Aurivillius

Plate II, fig. 1.

Rathbun, Bull. U. S. F. C., vol. XX for 1900, part 2, 1901, p. 64 .

S. W. of Pelican Island, Barbados, 1 mile; 38 fathoms; bottom of fine coral fragments; May 13 ; sta. $1 ; 1$ ㅇ ovig.; carapace concealed dorsally by a calcareous coating which does not disguise the eharacteristic elevations.

\section{Subfamily Schizophrysinæ}

Thoe Puella Stimpson

Rathbun, Bull. U. S. F. C., vol. XX for 1900, part 2, 1901, p. 63.

Pillars of Hercules, Antigna; 2 t 3 ㅇ (1 ovig.).

\section{Mithrax spinosissimus (Lamarek)}

The Lazy Crab Hughes, Nat. Hist. Barbados, 1750, p. 262, pl.

XXV, fig. 1 (part: chelipeds and legs only).

Mithrax spinosissimus Rathbun, Bull. U. S. F. C., vol. XX for 1900 , part 2, 1901, p. 66 .

Barbados: W. N. W. of Lazaretto; N. N. W. of Pelican Island; 33 fathoms; bottom rocky; dredge; May 27; sta. 51 ; 3 young.

The largest of these, abont $9 \mathrm{~mm}$. long in the median line, shows a small spine on the basal antennal segment at the base of the next segment.

\section{Mithrax acuticornis Stimpson?}

Rathbun, Bull. U. S. F. C., vol. XX for 1900, part 2, 1901, p. 66 . 
Barbados; May 22; 1 juv. with carapace less than $6 \mathrm{~mm}$. long. Agrees in the main with $M$. acuticornis but the carapace is smoother than usual, the tubercles being fewer and lower.

\section{MIthrax PILOSUs Rathbun}

Bull. U. S. F. C., vol. XX for 1900, part 2, 1901, p. 66.

Pillars of Hercules, English Harbour, Antigua; 1 t juv.

Barbados; 1 t.

Not before noted from Barbados, but occurring at Guadeloupe and Caracas.

\section{Mithrax hemphilli Rathbun}

Bull. U. S. F. C., vol. XX for 1900, part 2, 1901, p. 69.

English Harbour, Antigua; shore; 1 t.

\section{Mithrax verrucosus Milne Edwards}

Mag. Zool., vol. II, 1832, cl. VII, pl. IV and explanation.

Pillars of Hercules, English Harbour, Antigua; 1 t, medium size.

Fort Barclay, English Harbour; July $9 ; 1$ \& juv.

English Harbour; shore; 1 \& juv.

Pelican Island, Barbados; 1 t juv.

Not previously recorded from Barbados; oceurs at Guadeloupe, Martinique and on the coast of Brazil.

Mithrax pepressus A. Milne Edwards

Bull. U. S. F. C., vol. XX for 1900, part 2, 1901, p. 68.

English Harbour, Antigua; shore; 1 t medium, 1 juv.

Mithrax pleuracanthus Stimpson

Bull. U. S. F. C., vol. XX for 1900, part 2, 1901, p. 68.

Barbados; 1 t juv. From coral heads; May 27; 2 t 1 \% ovig., all small.

Not recorded previously from Barbados, or farther south than Martinique.

\section{Mithrax Caribbaeus Rathbun}

Plate III

Proc. Biol. Soc. Washington, vol. XXXIII, 1920, p. 23.

Barbados; 2 \&, one rather large, the other middling small. 
Length of earapace of larger $q$ on median line 53.5, extreme width $71 \mathrm{~mm}$. Length of smaller o 20.8 , width $24.4 \mathrm{~mm}$.

Approaches $\boldsymbol{M}$. hispidus in its large size and general shape, but the carapace is a little narrower, and the crenulation of the prehensile edges of the fingers in the gape persists in the old, while it disappears in old hispidus.

Differs from all its allies in the arrangement of tubercles or tubercles and spines on the postero-lateral region. There is a postero-lateral spine in the young and middle-sized, which becomes a tubercle in the old; it is situated not far behind the spine at the lateral angle of the carapace, and forms the outermost of a transverse row of three, which is subparallel to another row of three tubereles.

Barbados is the furthest east for this species; it has been taken at Porto Rico, St. Thomas and Venezuela.

\section{Mithrax (Mithraculus) sculptus (Lamarck)}

Rathbun, Bull. U. S. F. C., vol. XX for 1900, part 2, 1901, p. 71.

Pillars of Hercules, English Harbour, Antigua; 14 t 6 (4 ovig.).

English Harbour; 1 t.

Pelican Island, Barbados; 4 t.

Barbados; under sea anemone; 3 t 1 .

M. sculptus is usually olivaceous, the color persisting in alcohol. The 4 specimens taken from under sea anemones are an exception, as they are reddish brown, in alcohol.

\section{Mithrax (Mithraculus) CORYPhe (Herbst)}

Rathbun, Bull. U. S. F. C., vol. XX for 1900, part 2, 1901, p. 71 .

Pillars of Hercules; English Harbour, Antigua; 6 t 7 क (4 ovig.).

Ft. Barclay, English Harbour; July $9 ; 1$ t.

Pelican Island, Barbados; 2 t 1 ․ Tide pool; May 11; 1 t 2 앙.

Barbados; 1 t. From coral head; June 4; 1 t. Shore; 1 \% ovig. Under sea anemones; 3 t 5 \% (4 ovig.) 1 juv. 
Mithrax (Mithraculus) forceps (A. Milne Edwards)

Rathbun, Bull. U. S. F. C., vol. XX for 1900, part 2, 1901, p. 70 .

1 mile S. of sta. 19, off Needham Point, Barbados; 84 fathoms; bottom rocky; sta. $20 ; 1$ \& ovig.

Barbados; 2 t 3 juv.

\section{Mithrax (Mithraculus) ruber (Stimpson)}

Rathbun, Bull. U. S. F. C., vol. XX for 1900, part 2, 1901, p. 69.

Pelican Island, Barbados; 1 ᄒ 1 \% juv.

Needham Point, Barbados; May 18; 3 t 1 \% immature. By diver; 1 o.

1 mile S. of sta. 19, off Needham Point; 84 fathoms; bottom rocky; sta. $20 ; 2$ t 3 \%.

Okra Reef, Barbados; May $13 ; 6$ t 6 \&, all small.

Barbados; shore; 1 \%. May $15 ; 7$ t 4 \% (2 ovig.) 2 juv. May 22; 1 t. On old coral; May $31 ; 1$ t 1 \& immature. From coral heads; June 4; 4 t 1 \& ovig. 1 juv.

Not heretofore knowll south of Guadeloupe.

Mithrax (Mithraculus) cinctimanus (Stimpson)

Rathbun, Bull. U. S. F. C., vol. XX for 1900, part 2, 1901, p. 70 .

English Harbour, Antigua; shore; 1 \&, immature.

Mirrophrys bicornutus (Latreille)

Rathbun, Bull. U. S. F. C., vol. XX for 1900, part 2, 1901, p. 72.

Pillars of Hercules, English Harbour, Antigua; 10 t 5 \& (2 ovig.) 1 juv.

English Harbour, Antigua; shore; 4 t 2 \& (1 ovig.).

Antigua; 1 \& ovig., with the slender, slightly divergent, ineurved horns figured by A. Milne Edwards, in Crust. Rég. Mex., 1873, pl. XIV, fig. 2.

Bathsheba, Barbados; 3 \& ovig., 1 juv.

Pelican Island, Barbados; May 11; 3 \& (1 ovig.) 1 juv. Tide pool; May $11 ; 2$ б. Мау $13 ; 1$ б.

Needham Point, Barbados; May 18; 1 \& juv.

Barbados; 4 t 2 q ovig. Under sea anemones : 1 t, soft shell. 


\section{Microphris INTERRUPtus Rathbun}

Plate II, fig. 5.

Proc. Biol. Soc. Washington, vol. XXXIII, 1920, p. 24.

Fort Barclay, English Harbour, Antigua, July 9; 1 ᄒ 1 \& juv.

Needham Point, Barbados; May 18; 1 t.

Known previously only from Cuba, the type locality.

Measurements.-The male from Needham Point is only slightly larger than the type male; the male from Fort Barclay is considerably larger, total length of carapace 16.7, length of horns 2.4 , width of carapace without spines 13.6 , with spines $13.3 \mathrm{~mm}$. The carapace is widest above the bases of the first ambulatory legs where it exceeds slightly the width between the tips of the postero-lateral spines, which are above the bases of the second ambulatory legs. The egg-bearing female is about the same size as the male and is concealed beneath a mass of algae and other small organisms.

Relationships.-M. bicornutus is very widespread and abundant, and a very variable species, but the form which I call interruptus appears to be consistently different. It differs from $b i$ cornutus in being wider in proportion to its length, and wider across the orbits in proportion to its posterior width; in the greater prominence of the oblique branchial protuberances which are in line with the postero-lateral spine; in the more transverse direction of the arch of four tubercles on the intestinal region; in the shorter and more transverse tooth at the antero-external angle of the basal antennal segment, which is very little advanced in dorsal view beyond the preorbital angle, and in ventral view gives the segment much greater relative width than in bicornutus; in the presence of a small but well-developed tooth or lobe on the infra-orbital margin, just outside the antennal segment; this tooth is lacking in bicornutus.

Stenocionops furcata (Olivier)

The Horned Crab, Nat. Hist. Barbados, 1750, p. 266, pl. XXV, fig. 3.

Stenocionops furcata Rathbun, Bull. U. S. F. C., vol. XX for 1900, part 2, 1901, p. 73 . 
Barbados; in shore 200 yards from sta. 22 ( $1 / 4$ mile E. of sta. 21 , in shore 400 to 500 yards); 35 fathoms; bottom rocky; tangles; May 20 ; sta. $24 ; 1$ t.

\section{MaCROCOELOMA TRISPINOSUM (Latreille)}

Milne Edwards, Hist. Nat. Crust., vol. I, 1834, p. 336.

English Harbour, Antigua; shore; 1 \& ovig., overgrown with sponge.

\section{MaCrocoeloma trispinosum nodipes (Desbonne)}

In Desbonne and Schramm, Crust. Guadeloupe, 1867, p. 15, pl. V, fig. 13.

English Harbour, Antigua; shore; 1 t, 1 juv.

Macrocoeloma subparallelum (Stimpson)

Rathbun, Bull. U. S. F. C., vol. XX for 1900, part 2, 1901, p. 74 .

Bathsheba, Barbados; 1 q ovig.

Pelican Island, Barbados; tide pools; May 11; 1 q immature.

Barbados; 1 \%. Shallow water; under large anemone; $1 \%$ ovig.

The specimens are almost concealed by seaweed, alcyonarians and other foreign substances.

First occurrence at Barbados; known from Guadeloupe and Old Providence.

\section{Macrocoeloma eutheca (Stimpson)}

Pericera eutheca Stimpson, Bull. MI. C. Z., vol. II, 1871, p. 112.

S. W. of Pelican Island, Barbados, 1 mile; 38 fathoms; bottom of fine coral fragments; May 13; sta. 1; 1 t.

W. by N. of Telegraph Station, Barbados; $1 / 2$ mile off shore about edge of drop off; $60-70$ fathoms; tangles; June 1 ; sta. 66 ; 1 \%.

First oceurrence at Barbados, though taken at St. Croix and Colon.

\section{MACROCOELOMA INTERMEDIUM Rathbun}

Bull. U. S. F. C., vol. XX for 1900, part 2, 1901, p. 75.

Off Lazaretto, Barbados; 20 fathoms; bottom rough; tangles; June 6 ; sta. $87 ; 1$ \& immature.

First record at Barbados, though taken at Dominica and Colon. 
Picroceroides tubularis Miers

Bull. U. S. F. C., vol. XX for 1900, part 2, 1901, p. 76.

Shoal Bank, Barbados, about 3 miles W. of Needham Point; 20-40 fathoms; sponge bottom; sta. 101; 1 juv.

Not before taken near Barbados, but off St. Thomas and the coast of Brazil.

\section{Pitho mirabilis (Herbst)}

Rathbun, Bull. U. S. F. C., vol. XX for 1900, part 2, 1901, p. 78.

Pillars of Hercules, English Harbour, Antigua; 1 . 


\section{BIBLIOGRAPHY}

Desbonne and Schramm. Crustacés de la Guadeloupe d'après un manuscrit du Doeteur Isis Desbonne eomparé avec les échantillons de crustacés de sa collection et les dernières publieations de MIM. Henri de Saussure et William Stimpson. 1 1 partie. Brachyures. Basse-Terre. 1867. [Edited by Alphonse Schramm.]

Edwards, A. Milne. Reports on the Results of Dredging under the Supervision of Alexinder Agsssiz, in the Gulf of Mexico, and in the Caribbean Sea, 1877, '78, '79, by the U. S. Coast Survey Steamer "Blake", Lient.-Commander C. D. Sigsbee, U. S. N., and Commander J. R. Bartlett, U. S. N., Commanding. VIIT. Etudes préliminaires sur les Crustacés.

Bull. Mus. Comp. Zoöl. at Harvard College, vol. VIII, No. 1, Cambridge, 1880, pp. 1-68, pls. I and II.

Edwards, A. Milne. Reeherehes Zoologiques pour servir a l'histoire de la faune de l'Amérique Centrale et du \exique, $5^{e}$ partie, Paris, 1881. Etudes sur les Xiphosures et les Crustacés de la Région Mexieaine, 1873-1880. 368 pp., 61 pls.

Edwards, A. Milne, and E. L. Bouvier. Reports on the Results of Dredging under the Supervision of Alexander Agassiz, in the Gulf of Mexico (1877-78), in the Caribbean Sea (187879), and along the Atlantic Coast of the United States (1880), by the U. S. Coast Survey Steamer" "Blake", Lient.-Com. C. D. Sigsbee, U. S. N., and Commander .J. R. Bartlett, U. S. N., Commanding. XXXIX. Les Dromiacés et Oxystomes.

Nem. Mus. Comp. Zoöl. at Harrard College, vol. XXVII, No. 1, Cambridge, 1902, pp. 1-127, pls. J-XXV.

Edwards, H. Milne. Sur les Crustacés du genre Mithrax.

Mag. Zool., vol. II, Paris, 18:32, classe VII, pls. 1-V.

Edwards, H. Milne. Histoire Naturelle des Crustacés, vol. I, Paris, 1834, xxxv and $468 \mathrm{pp}$. 
Hughes, Griffith. The Natural History of Barbados. London, 1750. Book IX. Of Crustaceous Animals. Pp. 261-266, pl. $\mathrm{XXV}$.

Rathbun, MARY J. List of the Decapod Crustacea of Jamaica. Ann. Inst. Jamaica, vol. I, No. 1, 1897, pp. 1-46.

Rathbun, Mary J. The Brachyura of the Biological Expedition to the Florida Keys and the Bahamas in 1893.

Bull. Lab. Nat. Hist. State Univ. Iowa, vol. IV, 1898, pp. 250-294, pls. I-IX.

Rathbun, Mary J. The Brachyura and Macrura of Porto Rico.

Bull. U. S. Fish Comm., vol. XX for 1900, part 2, 1901, pp. 1-137, pls. I and II.

Rathbun, Mary J. The Grapsoid Crabs of America.

Bull. U. S. Nat. Mus., No. XCVII, 1918, pp. 1-461, pls. I-CLXI.

Ratubun, Mary J. New species of Spider Crabs from the Straits of Florida and Caribbean Sea.

Proc. Biol. Soc. Washington, vol. XXXIII, 1920, pp. 23-24.

Stimpson, William. Notes on North American Crustacea, Nos. $\mathrm{I}$ and II.

Ann. Lyc. Nat. Hist. N. Y., vol. VII, New York, pp. 49-93 (1859), pp. 176-246 (1860), pls. I, II and V.

Stimpson, Willinir. Preliminary Report on the Crustacea dredged in the Gulf Stream in the Straits of Florida.

Bull. Mus. Comp. Zoöl. at Harvard College, vol. II, Cambridge, 1871, pp. 109-160. 


\section{EAPLANATION OF I'LATES}

Plate III and plate II, fig. 1, are from photographs loaned by the I. S. National Musemm. The other photograplss on plate II were made by 11 r. Clarence R. Shoemaker and retourhed by Mlr. Seward II. Rathbun who mate the drawings on plate $\mathrm{I}$.

\section{Plate I}

ritumnus burbutensis. o. Barbados

Fig. 1. Majol chela, $\times 8$.

2. Minor chela, $x$ 9.4.

3. An ambulatory leg. $X 8$.

4. Carapace, with eyes and antemmae, $X 7$.

\section{Plate II}

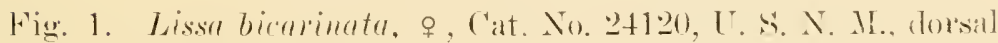
view, carapace $9.6 \mathrm{~mm}$. long.

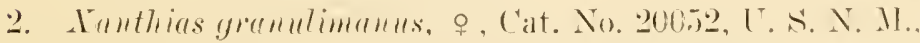
ventral riew, $\times 3$. Carapare $9.2 \mathrm{~mm}$. wide.

3. Same, dorsal view, $\times: 3$.

4. IIerbstia depressu, o, Barbarlos, $\times 222-3$.

5. Microplerys intermptus, t, Fort Barelay, $\times 3$. (Garapace, including horms. $16.7 \mathrm{~mm}$. long.

Plate III

Mithrax curibbacus, t holotype. Cat. No. J036:3, U. S. N. M. dorsal view, carapace, inchuding horns, $66.3 \mathrm{~mm}$. long. 

PLATE I
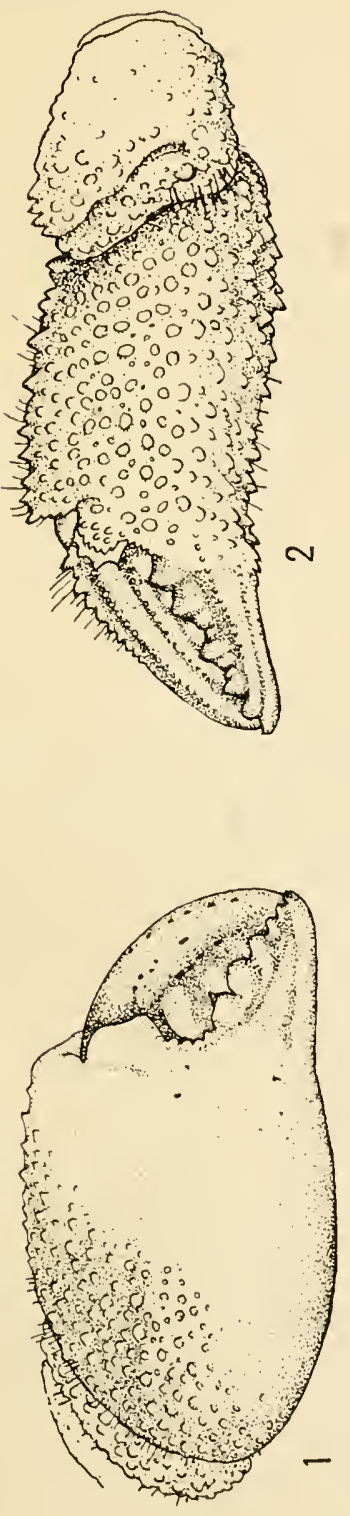
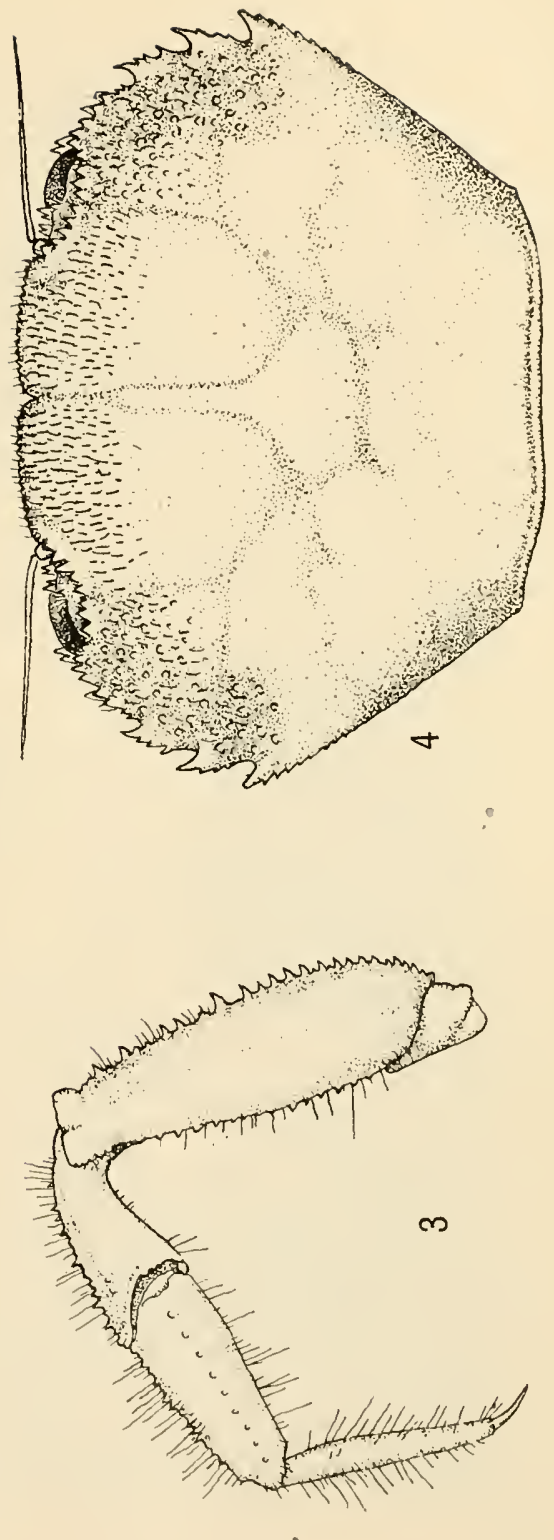

PLATE II

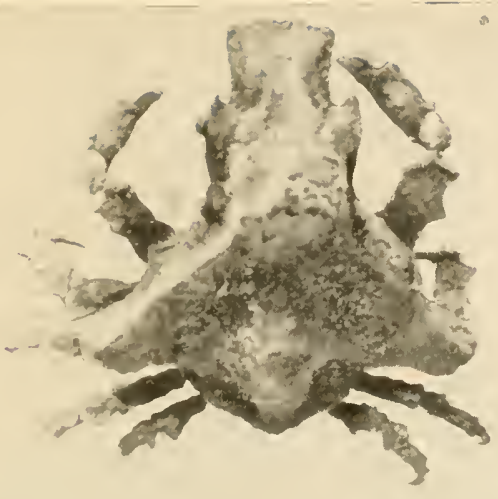

I

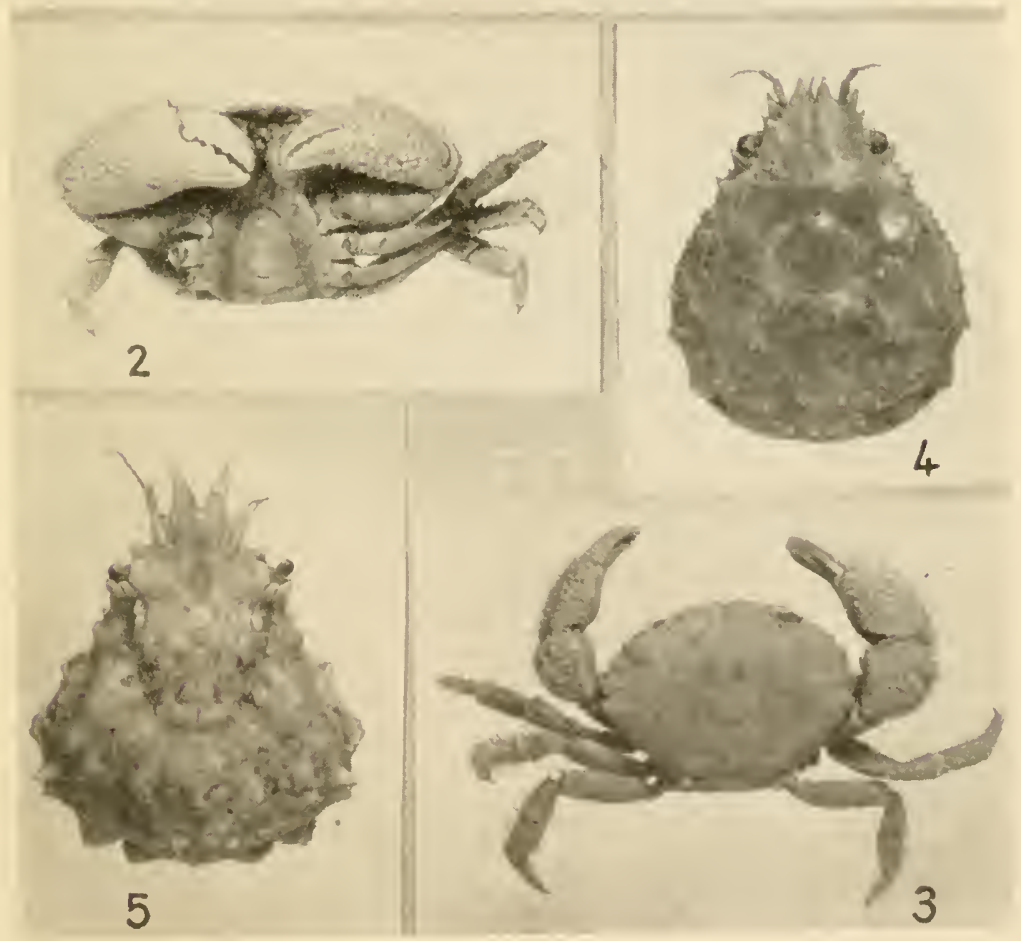



I'LA'TE III

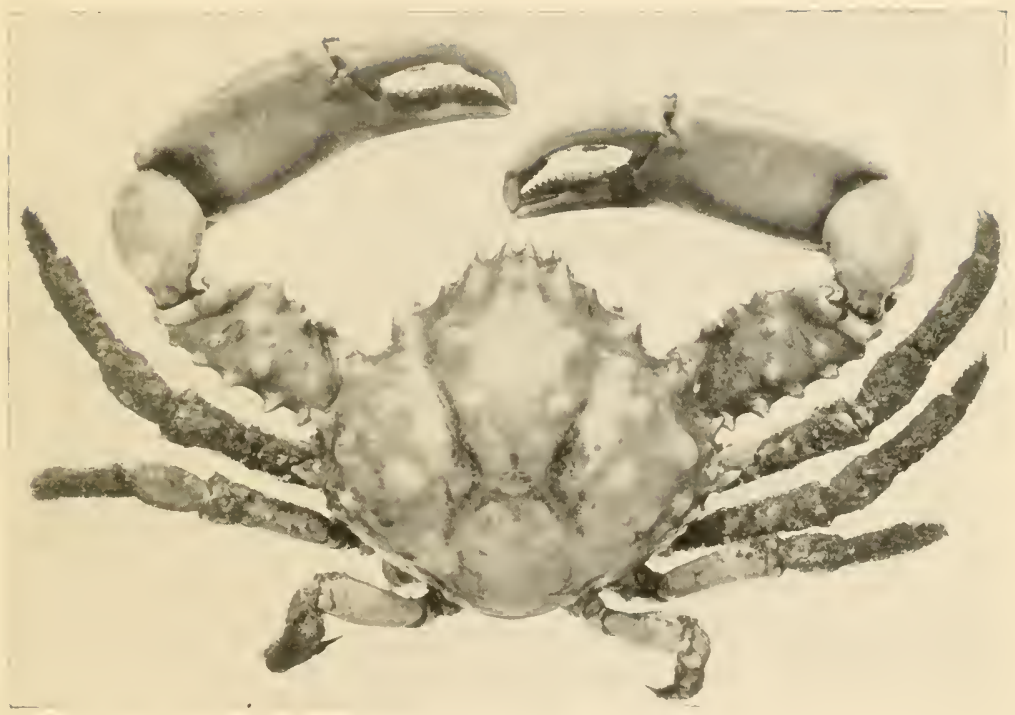





\title{
REPORT ON THE TANIDACEA AND ISOPODA
}

\author{
Collected by the Barbados-Antigua Expedition \\ from the University of Iowa in 1918 \\ PEARL L. BOONE
}

Aid, Division of Marine Invertebrates, U. S. National Museum

The Isopod Crustacea of the Barbados-Antigua Expedition conducted by the State University of Iowa during the summer of 1918, though a surall collection, has proven quite interesting. Of the six species represented, one, Exosphaeroma muttingi, is new to science; another, Porcellio parvicornis Richardson, represents the second record of this species, which was described from a single specimen secured in the Bermudas in 1901.

A single representative of the Tanaidacea was taken; namely, Apsuedes espinosus Moore.

An annotated list of the material collected and diseussion of the new species is herewith presented. The drawing of the latter was made by Mr. Seward H. Rathbun under my direction.

\section{TANAIDACEA}

\section{Family Apseudidæ}

\section{Genus Apseudes Leach}

\section{Apseudes espinosus Moore}

Apseudes espinosus Moore, Bull. U. S. Fish Commission XX, pt. 2, 1902, pp. 165-166, pl. 7, figs. 1-6. Richardson, Bull. 54, U. S. Nat. Mus., 1905, p. 38, figs. 34 a-f.

One male specimen of this species was collected at Station 1, Barbados, 1918, and is in the collection of the State University of Iowa.

Moore described the type from a female, taken by the U. S. Bureau of Fisheries steamer "Fish Hawk", at Station 6079, off St. Thomas, Porto Rico, 20 fathoms, on coral bottom. 
Representatives of this spccies from the following localities are in the collections of the U. S. National Museum; from among algae, No Name Key, Fla.; off the Customs House, Mayaguez, Porto Rico, Station 6651, in 4-6 fathoms; also from Station 6090 off Culebra Island, S. W. Culebrita, Porto Rico, in 16 fathoms.

\section{ISOPODA}

\section{Family Cirolanidæ}

Genus Cirolana Leach

Cirolana mayana Ives

Cirolana mayana Ives, Proc. Acad. Nat. Sci. Phil., 1891, pp. 186-187, pl. VI, fig. 6, figs. 3-10.-Richardson, Bull. 54, U. S. Nat. Mus., 1905, p. 87, fig. 66.

A single adnlt specimen, collected in sand, June 2, 1918, Barbados, was secured and is in the collections of the State University of Iowa.

Type locality: Port of Silam, Yucatan, 3 specimens. Subsequent records for this species are: Boqueron Bay and Culebra, Porto Rico (H. F. IIoore). Santa Marta, U. S. Colombia (Richardson). Brandon's, Barbados Beach; San Franeisco Bay, Lower California (Richardson, 1905). I doubt the validity of this last locality.

There are no specimens of Cirolana mayana Ives in the collections of the U. S. National Museum.

\section{Cirolana Parva Hansen}

Cirolana parva Hansen, Vidensk. Selsk., Skr. (6), V, 1890, pp. :340-341, pl. 2, figs. 6-6b, pl. 3, figs. 1-1d. Richardson, American Naturalist, vol. 34, 1900, p. 217. Proc. U. S. Nat. Mus., vol. 23, 1901, p. 514. Bull. 54, U. S. Nat. Mins., 1905, p. 111, figs. 93-94. Moore, Bull. U. S. Fish Com., 20, pt. 2, 1902, p. 167, pl. 8, figs. 6-8.

Sixteen specimens from Pelican Island, Barhados, werc collected June 13, 1918, 14 of which are in the collection of the State University of Iowa and two in the U. S. National Mruscum, Cat. No. 53882.

One specimen, taken with electric light at English Harbour, one taken at dredging station 1, Barbados, another from Station 
11, Barbados, also one labeled “'Barbados, May 15, 1918," are in the collections of the State University of Iowa.

Type localities:-Hansen states that he has examined representatives of the species from the following localities: St. Thomas, West Indies, 5 specimens (Krebs, 1867) ; St. Croix, West Indies, 2 specimens (Oersted); West Indies, 1 specimen (Kroyer); without locality but probably West Indies, 1 specimen; $25^{\circ}$ N. B., $34^{\circ}$ V. L., 2 specimens (Hygom) ; Samoa Islands, 1 specimen (Mus. Godeffroy). This last he offers with hesitation and fears the locality with specimen may be wrong, but states the specimens are identical with the West Indian material.

In addition, representatives of this species from the following localities are in the collections of the U. S. National Museum; between the delta of the Mississippi and Cedar Keys, Florida, Stations 2369-74, 25-74 fathoms depth; Station 2406, Gulf of Mexico, Lat. N. $28^{\circ} 46^{\prime}$, Long. W. $84^{\circ} 49^{\prime}, 26$ fathoms; Station 7293, Gulf of Mexico, off Northwest Channel, $71 / 4$ fathoms depth, off Biscayne Key, Florida, 16-34 ft. depth; Grassy Key Lake, off Grassy Key, Florida, Station 7431, 8 feet depth, No Name Key, Florida, banks, low tide; off Knights Key Channel, N. E. Bahia Honda Key, Florida, Station 7411, $10 \mathrm{ft}$. depth; Pigeon Key Lake, Florida, Station 7404, 101/2 ft. depth; Key West, Florida, among algae, below low tide; Key West, Florida; specimens from sponges, Lisbon Reef, Andros Island, Bahamas; in algae (Panicillus capitatus), Georgetown, Great Exuma, Bahama, shallow water about the keys, Esperanza, Cuba; from mangrove roots, Boque Islands, Montego Bay, Jamaica; Mayaguez, Porto Rico; from Porto Real, Porto Rico; Ponce, Porto Rico; Playa de Ponce, Porto Rico, on lighthouse reef, Arroyo, Porto Rico; Fajardo, Porto Rico; Boqueron Bay, Porto Rico; Ensenada Honda, Culebra, Porto Rico; off St. Thomas, Virgin Islands, U. S., Station 6080, 20 fathoms depth; St. Thomas, Virgin Islands, U. S.

\section{Family Excorallanidæ}

Excorallana Stebbing ${ }^{2}$

Excorallana subtilis (Hansen)

Corallana subtilis Hansen, Vidensk. Selsk. Skr. (6), V, 1890,

1 See Hansen for characters of family, Vidensk. Selsk. Skr. (6), V, 1890, pp. 311. $313,317,376$, Kjobenhavn.

2 Fauna and Geography of the Maldive and Laccadive Archipelagoes, II, Pt. 3, 1904, p. 704 . 
pp. 382, 383, pl. 7, figs. 3-3c, Richardson, Proc. U. S. Nat. Mus., XXIII, 1901, p. 519.

Excorallana subtilis Richardson, Bull. 54, U. S. Nat. Mus., 1905, p. 146, fig. 130 a-d.

A single immature specimen of this species was taken at Okra Reef, Barbados, May 13, 1918, and is in the collections of the State University of Iowa.

Hansen described this species from a single young female specimen in the process of ecdysis labelled "St. Thomas, Krebs, Aug. 24, 1858', which is in the Copenhagen Museum.

Two male specimens collected in the harbor of Key West, Florida, by Dr. Edward Palmer, in 1884, Cat. No. 13581, are in the collections of the U. S. National Museum. These specimens agree with Hansen's description except that they lack the two large tubercles at the base of the abdomen, but it must be recalled that the type was an immature female in process of eedysis.

\section{Excorallana oculata (Hansen)}

Three specimens of this species were collected with electric light at English Harbour, Barbados, 1918; two of these are in the collections of the State University of Iowa, the third is in the collections of the U. S. National Museum, Cat. No. 53886.

Hansen described the species from two specimens collected in the West Indies, by Krebs, 1866, and deposited in the Copenhagen Museum.

Three specimens, collected by the steamer "Albatross" at Station 2758 , in 20 fathoms of water, off Cape St. Roque, Brazil, are in the U. S. National Museum.

\section{Family Cymothoidæ}

Genus Anilocra Leach

\section{Anilocra laticauda Milne Edwards}

Anilocra laticauda Milne Edwards, Hist. Nat. Crust. III, 1840, p. 259.

Anilocra mexicana Saussure, Rev. Mag. Zool., 1857, p. 505.

Anilocra leachii (Kroyer) Schiödte \& Meinert, Naturhistorisk Tidsskrift (3), XIII, 1881-83, pp. 126-131, pl. IX, figs. 1-3. Richardson, American Naturalist, XXXIV, 1901, p. 528.- 
Moore, Report U. S. Com. Fisheries XX, Pt. 2, 1902, p. 172, pl. X, figs. 3-4. Richardson, Bull. 54, U. S. Nat. Mus., 1905, p. 227, fig. 230 .

Two adult and four young specimens of this well-known fish parasite were collected May 14, 1918, near Pelican Island, Barbados, and are in the collections of the State University of Iowa.

The type locality of the speeies was described "Habitat la mer" des Antilles".

The species has been recorded as parasitic on Ocyurus chrysurus, Bathystoma rimator, Haemulon plumieri, H. arcuatum, Upeneus martinicus, and Abudefduf saxtalis from a series of localities establishing a geographic range from Maryland to the Straits of Magellan.

The representatives of the species from the following localities are in the collections of the U. S. National Museum : on "Grunt," Jewfish Bush Lake, Florida; "on fish," Key West, Florida; Arroyo and Vieques, Porto Rico; West End Santa Lucia Bay, Cuba; Cape Cajon, Cuba; on parrot-fish, Montego Bay, Jamaica; on eye of yellow-tail, Ocyurus chrysurus, Montego Bay, Jamaica; "from angle of mouth (external) of Bathystoma rimator", Jamaica; from small yellow-tail, Snug Harbor, Nontego Bay, Jamaica; on head of Haemulon arcuatum, Cozumel, Yucatan; Cat. No. 7660, on fish, St. Thomas, West Indies; Buck Island, near St. Thomas, West Indies; 1 specimen on red-fish, St. Croix, West Indies; on Abudefduf saxatilis, Toso Point, Canal Zone, Panama; on A. saxatilis, Colon Reef, Panama; Cat. No. 20481, 2 specimens, Porlamar, Margarita Island, Venezuela; Rio de Janeiro, Brazil.

\section{Gemus Сумотнон Fabricius}

\section{Cymothoa oestrum (L.)}

Oniscus oestrum Linnaeus, Syst. Nat., 10th Ed., I, 1758, p. 636, No. 2 ; Fauna suecica, 2nd ed., 1761, p. 499, No. 2053; Syst. Nat., 12 ed., I, 1767, pt. 2, p. 1059, No. 2.

Asellus oestrum Olivier, Encycl. Méthod. IV, 1789, p. 253.

Cymothoa oestrum Fabricius, Entom. Syst. II, 1798, p. 505, No. 6,-Leach, Trans. Linn. Soc. London, XI, 1815, p. 372 ; Dict. Sci. Nat. XII, 1818, p. 362.

Cymothoa dufresnei Leach, Dict. Sci. Nat. XII, 1818, p. 352. 
Cymothoa immersa Say, Journ. Acad. Nat. Sci. Phila., I, 1818, pp. 399-400.

Cymothoa oestrum Desmarest, Consid. Gén. Crust., 1825, p. 309, pl. 47, figs. 6-7, Miers, Proc. Zool. Soc., 1877, pp. 671-672,Schiödte and Meinert, Naturh. Tidsskr. (3), 14, 1883-84, pp. 271-279, pl. 8, figs. 5-13. Richardson, American Naturalist, 34, 1900, p. 221 ; U. S. Nat. Mus., 23, 1901, p. 530 ; Bull. 54, U. S. Nat. Mus., 1905, p. 254, fig. 263.

Four adult specimens of this species were found parasitic on the tongue of "horse-eye eavalli" (fish), May 28, 1918, Barbados. About twenty-five very young of the second stage were collected in sand, Barbados, June 2, 1918. One of the adults is in the collections of the U. S. National Museum, Cat. No. 53883. The remainder are in the collections of the State University of Iowa.

The type locality of this well-known parasite was recorded "Habitat in Oceano".

It has been recorded as taken from the following hosts: Caranx latus, C. ruber, "jack-fish", from branchial eavity; "red Fish" stomach, in the tongue of Scombroid fishes, parasitic on the mouth of Priacanthus arenatus and Trachurops crumenopthalmus; Sparisoma abilgaardi, Cynocion ciorchus, on Strombus giganteus, the various localities cited giving a geographic range from the shore of Virginia to the southern shores of the Caribbean Sea, also the coast of Peru.

The representatives of this species from the following localities are in the collections of the U. S. National Museum: from the mouth of Caranx ruber, Tortugas, Florida; Key West, Florida; parasitic on Trachurops crumenopthalmus, and on Priacanthus arenatus, Bermuda ; Cat. No. 28678, from the "stomach of redFish", near Barbados; from parrot-fish, Sparisoma abilgaardi, Nontego Bay, Jamaica; from the branchial eavity of jack fish, Caranx species, Jamaica; Curaçao, Feb., 1884; from mouth of fish, St. Thomas, Virgin Islands, U. S.; 1 young male specimen on the gills of Cynocion ciorchus, Colon market, Colon, Canal Zone, Panama; Swan Island, Caribbean Sea. 


\section{Family Sphaeromidæ}

\section{SphaEroninae hemibranchiatae}

\section{ExosphaEroma NutTingi new species}

\section{Figures 1-2}

Body elongate-ovate, smooth, ground color creamy yellowish, irregularly mottled with fine black splotehes.

Head two-thirds as long as wide with frontal margin produced to a median point on either side of which it is moderately excavated and thence recurvate for the reception of the antennal joints. Eyes large, round, occupying the entire postlateral area of the head. First antennae with the basal article elongate, broad, flattened, second article half as long as the first, very convex; the third article slender, cylindrical, two-thirds as long as the first, and a flagellum of eight slender subequal articles and extends almost to the posterior margin of the first thoracic segment. The second antennae have the first and second joints short, subequal, the third and fourth joints each slightly longer than the second, the fifth joint slightly longer than the fourth and a flagellum of eleven tapering subequal articles which extends almost to the posterior margin of the third segment. The maxillipeds have the lobes of the distal four joints much produced.

The first thoracic segment is slightly longer than any of the others which are subequal, the epimera are easily distinguished and have their respec. tive lateral margins rounded and sculptured. The seven pairs of legs are similar, subequal, irregularly, sparsely set with spines along the inner side.

The abdomen has the first thoracic segment a trifle longer than the seventh thoracic segment and bears three transverse lines indicating the coalescence of four segments, the terminal segment is convex, domelike, with the posterior marginal area on a slightly lower plane than the central area; the posterior margin is broadly rounded, the extreme median area has a broad shallow excavation on the ventral surface, the distal termination of this channel causes a vague almost invisible truncation of the dorsal margin. The uropoda have the peduncle rounded, knob-like, its articulation with the inner branch being difficult to distinguish; the inner branch has the inner lateral margin relatively straight, the outer margin broadly rounded, the distal margin crenulate; the outer blade is four-fifths as long as the inner blade and is broadly oval with its posterior margin erenulate.

Pleopoda one and two are subequal, similar, fringed; pleopoda three has the exopod two-jointed; pleopoda four and five have the endopods thick, of fleshy aspect, with deep, essentially transverse folds, the exopods submembraneous and rather pellueid, two jointed.

The present species may be distinguished from Exosphaeroma crenulatum Richardson* by the fact that it has three transverse lines on the first abdominal segment indicating the coalescence of four segments; these lines

*Exosphaeroma crenulatum Richardson, Bull. 54, U. S. Nat. Mus., 1905, p. 298, figs. $317-318$. 
are quite differently placed from the two lines of coalescence of Exosphaeroma crenulatum; the posterior margin of the telson is different, the uropoda have both blades slightly crenulate only on the distal end, and the lobes of the second, third and fourth joints of the palp of the maxilliped are much produced.

The holotype and eleven paratypes are in the collections of the State University of Iowa. Six additional paratypes are in the collections of the U. S. National Museum, Cat. No. 53884. All were collected from among the spines of a sea-urehin, Barbados. Named for Professor C. C. Nutting.

\section{ONISCOIDEA}

\section{Family Oniscidæ}

Genus PoRcellio Latreille

\section{PORCELlio PARvicornis Richardson}

Porcellio parvicornis Richardson, Trans. Conn. Acad. Sciences, XI, 1902, p. 302, pl. 40, fig. 57.—Bull. 54, U. S. Nat. Mus., 1905, p. 616 , fig. 667 .

Three specimens of this species were collected at Indian River, Barbados, May 21, 1918. Two specimens are in the collections of the State University of Iowa and one in the U. S. National Museum, Cat. No. 53885. These represent the second record of this species, which was described from a single specimen collected by Prof. A. E. Verrill at the Bermudas in 1901, and deposited in the collections of Peabody Museum, Yale University.

\section{EXPLANATION OF PLATE}

Fig. 1. Exosphaeroma muttingi new species, type.

Fig. 2. Exosphaeroma nuttingi maxilliped. 
PLATE I
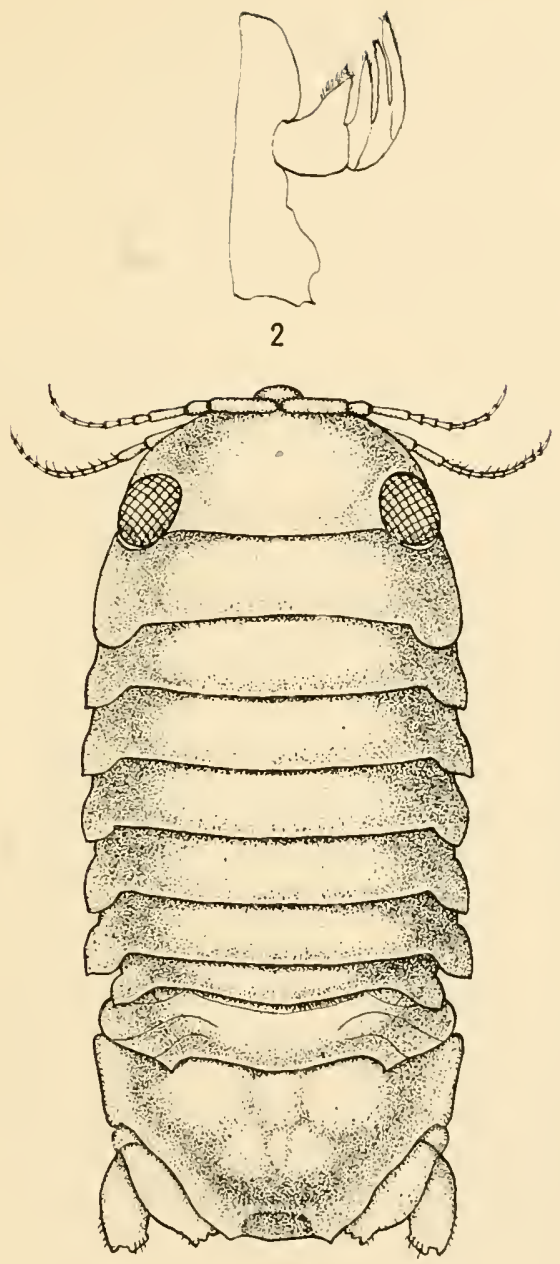

1 



\section{REPORT ON THE AMPHIPODS}

Collected by the Barbados-Antigua Expedition from the University of Iowa in 1918

Clarence R. Shoemaker

Aid, Division of Marine Invertebrates, U. S. National Museum

The Amphipod collection of the expedition is represented by 191 specimens which are included in sixteen species. The records are all new for Barbados and four of the species (Ampelisca lobata, Lembos concavus, Chevalia aviculae, and Ampithoe intermedia) are reported for the first time from the east coast of America.

\section{Lysianopsis alba Holmes}

Station 1, one mile S. W. of Pelican Island, Barbados, May 13, 1918, 38 fins.

2 specimens

This species was described by S. J. Holmes in 1905 from Woods Hole, Mass. It was reported by Arthur S. Pearse in 1912 from Gulf of Mexico. J. B. Henderson and Paul Bartsch found it off Cape San Antonio, Cuba, in 1914, and in 1915 it was collected by myself at St. Thomas, W. I.

\section{Ampelisca lobata Holmes}

Station 1, one mile S. W. of Pelican Island, Barbados, Nay 13, 1918, 38 fms.

1 specimen

This is the first report of the occurrence of this species upon the east coast of North America, the species having been described by S. J. Holmes off San Nicolas Island, Southern California, in 1908.

\section{Amphilochus, species}

Pelican Island, Barbados, May 13, 1918.

2 specimens

These specimens are too imperfect for identification.

\section{Leucothoe SPinicarpa (Abildgaard)}

Pelican Island, Barbados, May 13, 1918. 1 specimen (immature) This species is found throughout the Arctic Ocean, on the 
coast of Norway, northern coast of Europe, British Isles, Azores, Bermuda, Mediterranean, Ceylon, Seychelles, British East Africa, Red Sea, McMurdo Sound (Antarctic), South Georgia, Cape Agulhas, South Orkneys, East coast of North America, Gulf of Mexico, St. Thomas, Jamaica, Cuba, and South Africa. This is the first mention of its occurrence at Barbados. Leucothoe spinicarpa frequently lives commensal in the branchial chamber of Ascidians.

\section{Batea Catharinensis Müller}

Pelican Island, Barbados, May 13, 1918.

3 specimens

Batea catharinensis was discovered at Desterro, Brazil, and in 1865 Fritz Müller created the genus for it. No members of the genus were again met with until 1900 when some specimens were found near Woods Hole, Mass., and described by S. J. Holmes as Batea secunda. The specific differences which this author points out, however, are very slight and the two species will probably prove to be the same. Batea catharinensis has also been found at Chesapeake Bay, Skull Creek, S. C., mouth of May River, S. C., and now at Pelican Island, Barbados.

\section{Pontogeneia verrilli Kunkel}

Pelican Island, Barbados, May 13, 1918.

1 specimen

In 1910 B. W. Kunkel described this species from Bermuda and this single specimen now from Barbados marks the second record.

\section{Maera inaequipes (A. Costa)}

Pelican Island, Barbados, May 13, 1918.

46 specimens

This species has been reported from the Azores, Mediterranean, Bermuda, Cuba, and South Africa; and the present record is the first for Barbados.

\section{Elasmopus rapax A. Costa}

Pelican Island, Barbados, May 13, 1918.

48 specimens

This species has been reported from Norway, British Isles, France, Azores, Bermuda, Gulf of Mexico, Jamaica, Cuba, and now for the first time from Barbados. 
9. Orchestia platensis Kroyer

Station 1, one mile S. W. of Pelican Island, Barbados,

May 13, 1918, 38 fins.

1 specimen

Beach near Pelican Island, Barbados, May 27, 1918. 10 specimens

This Amphipod has been found upon the beaches of nearly all the temperate and tropical regions of the earth; this, however, is the first record for Barbados.

\section{Lembos concavus Stout}

Pelican Island, Barbados, May 13, 1918.

17 specimens

In 1913 Vinnie Ream Stout described this species from Laguna Beach, California. The specimens taken at Barbados are smaller but agree very well with the description. This is the first appearance of this species on the east coast of America.

11. Eurystheus lina Kunkel

Pelican Island, Barbados, May 13, 1918.

35 specimens

The first specimens of this species were found at Bermuda in 1903 and described by B. W. Kunkel in 1910. Specimens have been taken also at Tortugas, Florida, and Porto Rico and this record from Barbados extends the range much to the south.

\section{Eurystheus, species}

Station 1, one mile S. W. of Pelican Island, Barbados.

May 13, 1918, 38 fathoms.

1 specimen

This single, female specimen is in too imperfect a condition for specific identification.

\section{Chevalia aviculae Walker}

Pelican Island, Barbados, May 13, 1918.

18 specimens

This species was found by Herdman and Hornell at Ceylon in pearl oyster washings, and deseribed by A. O. Walker in 1904. It was later taken at Saya de Malha Bank, Cargados Islands, and South Africa. Walker thinks this is probably a tube-building species but nothing yet is known of its habits. The species described by Arthur S. Pearse as Chevalia mexicana in 1912 from the Gulf of Mexico will probably prove to be the same as Walker's species. This is the first record for Barbados. 


\section{Amphithoe intermedia Walker}

Barbados, under sea anemones.

3 specimens

A. O. Walker described this species from Ceylon in 1904, and in $\mathbf{1 9 0 5}$ he reported it from the Maldive Islands. Chevreux in 1907 reported it from the Tuamotu Islands. In $1909 \mathrm{~A}$. O. Walker recorded it from Praslin Reef, Zanzibar, and Red Sea. The specimens from Barbados agree with those figured by Chevreux in having the broad rounded lobe on the lower, anterior corner of the second joint of the second gnathopods.

\section{Grubia compta (Smith)}

Barbados, June 4, 1918 (from coral heads).

1 specimen

This species was described by S. I. Smith in 1873 and was said to range from North Carolina to Cape Cod. In 1912 Arthur S. Pearse reported it from Harbor Key and Key West, Florida. The present record is the first from Barbados.

\section{Podocerus brasiliensis (Dana)}

Pelican Island, Barbados, May 13, 1918.

1 specimen

This is a tropical Atlantic species which heretofore has been reported only from Rio Janeiro and Antigua. 


\title{
REPORT ON THE ECHINOIDEA
}

Collected by the Barbados-Antigua Expedition from the University of Iowa in 1918

\author{
Hubert Lyman Clark
}

Museum of Comparative Zoölogy, Cambridge

The collection of Echinoidea made by the party from the University of Iowa, which under the leadership of Professor C. C. Nutting, visited Barbados and Antigua in the summer of 1918 , is not a large one but it represents well the typical littoral West Indian fauna. The 229 specimens belong to 18 species, all but two of which are known, characteristic forms of the Caribbean region. The two exceptions are notable indeed, for each represents a genus not hitherto reported from the West Indies: one (Pseudoboletia) is recorded from the eastern Atlantic (Ascension Island) and the other (Centrostephamus) oceurs on the western coast of Mexico.

Of the 229 specimens, 178 belong to three very common West Indian species, Echinometra lucunter, Echinoneus cyclostomus and Brissus brissus. The equally common species, Centrechinus antillarum, Tripneustes esculentus and Lytechinus variegatus, are represented by very few specimens, presumably because their large size made extensive series undesirable and their commonness made such series unnecessary. These six eommon species occurred at both Barbados and Antigua. The only other echini found at the latter island were Eucidaris tribuloides and Clypeaster rosaceus, which are also common and widespread species. But no Clypeaster was taken at Barbados.

The 18 species fall naturally into two divisions, those which occur along shore, or on reefs easily accessible at low tide, and those which are gotten only by dredging, trawling or the use of tangles. The former are the strictly "littoral" group; the latter belong rather to the "continental" fauna; of course members of the littoral group are often taken in deeper water, sometimes 
down to 50 or even 100 fms., but the species of the continental group do not seem to ever come up into the very shallow water.

The following list shows the echini of the present collection which belong to the strictly littoral group:

Eucidaris tribuloides

Centrechinus antillarum

Lytechinus variegatus

Tripneustes esculentus
Echinometra lucunter

Clypeaster rosaceus

Mellita sexiesperforata

Echinoneus cyclostomus

\section{Brissus brissus}

In a recent study of the littoral echinoderms of the West Indies (1919, Publ. 281, Carnegie Inst., pp. 51-74), I have recorded 7 of these 9 species from Barbados and 6 from Antigua, relying mainly on the field notes of Dr. W. K. Fisher who was a member of the Iowa party. The present collection adds Lytechinus variegatus to the fauna of Barbados and Clypeaster rosaceus and Echinoneus cyclostomus to the fauna of Antigua.

Of the remaining nine species, eight unquestionably belong to the continental groups. The ninth, the unique Pseudoboletia, may possibly prove to be littoral but the depth at which it was found is not recorded. The nine species are:

Stylocidaris affinis

Tretocidaris bartletti

Coelopleurus floridanus

Centrostephanus rubicingulus
Lytechinus callipeplus

Lytechinus euerces

Genocidaris maculatus

Pseudoboletia occidentalis

Agassizia excentrica

Excepting only the two new forms, all these species were taken by the "Blake" near Barbados, and also near Dominica, Montserrat or St. Cruz. Hence their oceurrence in the present collection was quite to have been expected. There are no specimens however of any of them from Antigua, all having been taken off the southwest coast of Barbados in 25-100 fms. But practically no dredging was done at Antigua except in the shallow harbors and bays, owing to the high seas outside those sheltered areas.

\section{LIST OF SPECIES}

EUCIDARIS TRIBULOIDES

Cidarites tribuloides Lamarck, 1816. Anim. s. Vert., 3, p. 56. 
Cidaris tribuloides A. Agassiz, 1872. Rev. Ech., p. 253; pl. Id and pl. II, figs. 1-3.

Eucidaris tribuloides Döderlein, 1887. Jap. Seeigel, p. 42.

There are three specimens of this well-known sea-urchin at hand; one, $38 \mathrm{~mm}$. in diameter with primary spines $35-38 \mathrm{~mm}$. long, from Falmouth Harbor, Antigua; one $25 \mathrm{~mm}$. with spines of about that length, from Carlisle Bay, Barbados, 30 fms.; and an interesting young individual, about $16 \mathrm{~mm}$. in diameter, without a locality label but apparently from Barbados. This last specimen has the primary spines very stout $(15 \mathrm{~mm}$. long by 2.5 $\mathrm{mm}$. in thickness) and more or less flaring at tip. Owing to the unusually well developed longitudinal ridges, the tips are quite florescent. The peculiarities of this specimen are probably associated with its youth, as the wear on the spines during maturity and their tendency to become the abiding-place of bryozoans and other fixed animals in their old age usually obliterate such features as are here noted.

\section{STYLOCIDARIS AFFINIS}

Cidaris affinis Philippi, 1845. Areh. Naturg., jhg. 11, 1, p. 351. See Mortensen, 1903, Ingolf Eeh., pt. 1, pl. I, fig. 1.

Dorocidaris papillata A. Agassiz, 1872. Rev. Ech., p. 254 (in part); pl. I, fig. 5.

Stylocidaris affinis Mortensen, 1909. Ech. Deutsch. SüdpolarExp., p. 52.

All of the 5 specimens of this cidarid in the present collection are young, the largest being scarcely half grown. The dianeter of the test is $9-17 \mathrm{~mm}$. and the primary spines are $2-2.3$ times as much, as a rule. In one specimen, however, $11 \mathrm{~mm}$. in diameter, the primaries are scarcely $15 \mathrm{~mm}$. long. There is some diversity in the coloration of these individuals, for in some the brownishred lines and markings in the interambulaca and on the abactinal system are quite distinet and in others they are nearly or quite wanting. The youngest primaries (i. e., those on the uppermost coronal plates) are normally quite different from the typical spines of the midzone, lacking the longitudinal dentate ridges. Occasionally the difference is emphasized by color; in 
one of the present series, these young spines are distinctly pink and unbanded. Fully developed primaries are more than twice the test-diameter, nearly cylindrical or terete, with the distinct, dentate, longitudinal ridges equally developed on all sides. In specimens less than half grown they are often conspicuously banded with 5-8 ill-defined reddish-brown zones.

The specimens in the present collection were taken at the following stations off the southwestern coast of Barbados.

Station 9. May 16,1918 . W. by N. Pelican Island, $21 / 2$ miles, $100 \mathrm{fms}$. Rocky bottom. Tangles. 2 specimens.

Station 34. May 23, 1918. S. E. of Hastings, 2 miles off shore, 80-90 fms. Rocky bottom. Tangles. 1 specimen.

Station 36. May 23, 1918. S. W. of Carlisle Bay, 2 miles off shore, 80-90 fms. Rocky bottom. Tangles. 1 specimen.

Station 46. May 25, 1918. N. N. W. Pelican Island, due west of Prospect, 2 miles off shore, 100 fms. Tangles. Bottom not recorded. 1 specimen.

TRETOCIDARIS BARTLETTI

Dorocidaris bartletti A. Agassiz, 1880. Bull. MI. C. Z., 8, p. 69. Tretocidaris bartletti Mortensen, 1903. INGouF Ech., p. 16. 1910, Bull. 74 U. S. Nat. Mus., pls. 2 and 3.

As with the preceding cidarid, all of the half-dozen individuals of this fine species are young, not nearly half grown, the test diameter ranging from 10 to $17 \mathrm{~mm}$., with the primary spines 15-27 mm. The color is commonly brighter than in affinis, the reddish tints being usually quite red and the test and small spines being often quite greenish. The bands on the spines are generally distinct and their number may be 8 or 9 , although the spines are shorter than in affinis. The two species seem to occur together and the young are easily confused. But aside from any matters of coloration, the form of the primary spines is sufficient for separating the two species, even if the very different globiferous pedicellariae cannot be found. In bartletti, the typical primaries are flattened and the lateral dentate ridges are more conspicuous, with bigger dentations, than those of either dorsal or lower surface. This makes a noticeable contrast to the cylindrical, uniformly ridged and generally longer spines of affinis. 
Barbados is the type-locality for bartletti and all of the specimens at hand came from there. At two of the following stations Stylocidaris was also taken.

Station 7. May 16, 1918. W. by N. Pelican Island, 2 miles, 80 fms. Rocky bottom. Tangles. 1 specimen.

Station 34. May 23, 1918. S. E. of Hastings, 2 miles off shore, 80-90 fms. Rocky bottom. Tangles. 1 specimen.

Station 35. May 23, 1918. S. W. of Needham Point, 21/2 miles off shore, 80-90 fms. Rocky bottom. Tangles. 1 specimen.

Station 36. May 23, 1918. S. W. of Carlisle Bay, 2 miles off shore, 80-90 fms. Rocky bottom. Tangles. 1 specimen.

Station 37. May 23, 1918. Off Pelican Island, 21/2 miles, 100 fms. Rocky bottom. Tangles. 1 specimen.

Station 44. May 25, 1918. N. W. Pelican Island and S. W. Lazaretto, 21/2 miles off shore, 90-100 fms. Medium coarse sand. Dredge. 1 specimen.

\section{CENTRECHINUS ANTILLARUM}

Cidaris (Diadema) antillarum Philippi, 1845. Arch. Naturg., jhg. 11, 1, p. 355 .

Diadema setosum A. Agassiz, 1872. Rev. Ech., p. 274 (in part). Centrechinus antillamum H. L. Clark, 1918. Bull. Lab. Nat. Hist. Iowa, 7, No. 5, p. 24.

Only a single small specimen of this most characteristic West Indian sea-urchin is in the present collection. It has the test about $30 \mathrm{~mm}$. in diameter while the primary spines are some 55 $\mathrm{mm}$. in length. They still show traces of the youthful banding, so striking a feature of much smaller specimens, but the general impression of this specimen is unicolor, though it is by no means really black.

In the "Narrative", Professor Nutting says this "black nuisance" is found "almost everywhere in shallow water, both on sandy and rocky bottom", about Barbados, while it is also "abundant" at Antigna. Apparently it is abundant wherever it occurs, for it is very common at the Tortugas and along the 
southern Florida coast, while at the other extreme of the West Indian region, on Buccoo Reef, Tobago, it is more abundant than at any other place where I have personally seen it.

CENTROSTEPHANUS RUBICINGULUS ${ }^{1}$ sp. nov.

Plate I, figs 1 and 2.

Test $12 \mathrm{~mm}$. in horizontal diameter, $5 \mathrm{~mm}$. high, decidedly flattened both above and below. Coronal plates 8 or 9 in each column, with no essential difference between ambulacra and interambulacra in this particular, but the interambulacra are about $4 \mathrm{~mm}$. wide at ambitus while the ambulacra are scarcely 3.5. Abactinal system large, $5 \mathrm{nmm}$. in diameter, covered with a fairly thick skin; all the oculars are insert; genital plates large, each with a long genital papilla, the length of which about equals the width of the plate; periproct about $2.3 \mathrm{~mm}$. across, covered with small roundish plates, set in thick skin. Uppermost abactinal primary spines, usually two of each vertical series, very small ( $1 \mathrm{~mm}$. long, more or less), smooth and club-shaped; all the other primaries, especially those of midzone which are the longest $(12-14 \mathrm{~mm}$.), very rough with the usual rings of minute spinelets. Peristome $7 \mathrm{~mm}$. in diameter, quite elosely covered with noll-ambulacral plates among which the five pairs of buccal plates are easily distinguished by their larger size and their clusters of pedicellariae and the spinelets so characteristic of Centrostephanus.

Pedicellariae of only two kinds so far as observed, ophicephalous and globiferous. The former have valves .25-.40 mm. long, with the loops 10-30 per cent more. These pedicellariae occur on the buceal plates and scattered about sparsely on the test; those on the test are considerably larger than those on the peristome. The globiferous pedicellariae, as in the other members of the genus, have the valves imbedded in heavily pigmented glands; these pedicellariae therefore, though very small, are made conspicuous by their black tips; the valves are $.22-.32 \mathrm{~mm}$. long and terminate in 4 short, subequal, somewhat spreading

\footnotetext{
${ }^{1}$ Rubus $=$ red + cingulus $=$ a zone or band, in reference to the banded spines.
} 
teeth; the general form of the valves is very similar to that found in C. rodgersii (See Mortensen, 1904. Siam Ech., pl. IV, fig. 19) except that in the Australian species there are six terminal teeth.

Peristome nearly white, but thick skin near mouth, tube-feet and gills yellowish. Pedicellariae pale reddish-yellow. From below ambitus upward the epidermis becomes thicker and steadily more and more pigmented until on the periproct it is quite black, especially at center. Primary spines whitish or glassy with 2-5 ill-defined but very distinct bands of red; the shade of red is between nopal-red and garnet-brown of Ridgway's pl. 1 (Color Standards and Nomenclature, 1912), and is quite free from any violet or purple tinge. The little club-shaped primaries on the abactinal plates have their distal halves bright rosepurple in striking contrast to their surroundings; the shade is very near the rhodamine purple of Ridgway's pl. XII.

Holotype from Station 101. June 13, 1918. On Shoal Bank, about 3 miles W. of Needham Point, 25-40 fms. Sponge bottom. Dredge.

It is a great pity that only a single specimen of this pretty little urehin was taken, for the genus, although occurring on the western coast of Mexico and also in the Mediterranean, has never been found hitherto in the West Indian region. Moreover it is probable that this is a very young specimen and it would be interesting to know to how large a size the species grows. The Australian specics, rodgersii, is the largest, reaching a diameter of $100 \mathrm{~mm}$., while the Mediterranean and Mexican species attain less than half that size, so far as we yet know. Neither species is at all well known. In every way, the West Indian species is nearest to that of the Mexican coast (coronatus) but it differs in several minor particulars. The coloration is noticeably different for in coronatus, the red which bands the spines is distinctly purplish and there is no trace of purple on the primaries of rubicingulus. Nore important is the difference in the globiferous pedicellariae; in coronatus, the narrow part of the blade is short and the terminal teeth are very long (see A. Agassiz and H. L. Clark, 1908, Mem. M. C. Z., 34, pl. 51, figs. 18, 19) while in rubicingulus, the narrow part of the blade is longer and the teeth are very much shorter. Of course, more material is nceded 
before all the differences between the two species can be clearly set forth.

A. Agassiz, 1872. Rev. Ech., p. 102. 1883, "Blake" Ech., pl. VII.

The specimens of this fine sea-urchin are all from the deeper water off southwestern Barbados. All are very young, the tests measuring only $6-13 \mathrm{~mm}$. in horizontal diameter. The spines are generally more or less badly broken but when these are intact they are usually 4-4.5 times the test diameter. The only diversity these individuals show is in the degree of brightness of their coloration. Some have no trace of blue or lavender abactinally while others, larger ones, have it quite well marked. The 7 specimens were taken at the following stations:

Station 7. May 16, 1918. W. by N. Pelican Island, 2 miles, 80 fms. Rocky bottom. Tangles. 1 specimen.

Station 19. May 18, 1918. 11/2 miles west of Needham Point, 80 fms. Rocky bottom. Dredge. 1 specimen.

Station 26. May 20, 1918. Due W. of Pelican Island, 75 fms. Rough, stony bottom. Dredge. 1 specimen.

Station 34. May 23, 1918. S. E. of Hastings, 2 miles off shore, 80-90 fms. Rocky bottom. Tangles. 1 specimen.

Station 36. May 23, 1918. S. W. of Carlisle Bay, 2 miles off shore, 80-90 fms. Rocky bottom. Tangles. 2 specimens.

Station 88. June 7, 1918. Lazaretto E. by N. 1/2 N., Pelican Island S. E. Depth (?). Fine sandy bottom. Dredge. 1 specimen.

\section{LYTECHINUS CALLIPEPLUS}

H. L. Clark, 1912 . Mem. MI. C. Z., 34, p. 251; pl. 96, figs. 4-6. The rediscovery of this interesting little species by Professor Nutting's party is of real importance and the five specimens obtained throw a great deal of light on the specific characters, for the holotype was only $8.5 \mathrm{~mm}$. in diameter and the largest known specimen was only $11.5 \mathrm{~mm}$., while the largest in the present series is $20 \mathrm{~mm}$. and another is 17 . These larger specimens show 
that the coloration is more striking and more distinctive than was suggested by the types. Each of the five specimens deserves separate consideration.

The smallest is only $7 \mathrm{~mm}$. in diameter and $4 \mathrm{~mm}$. high. The whole abactinal surface is more or less reddish with indefinite and inconspicuous blotches in the ambulacra and interainbulacra. The periproct, the proximal part of the oculo-genital ring and a large blotch at upper end of each interambulacrum are greenishwhite. The abactinal spines are nearly all coral-red, but some have whitish tips.

The next specimen is $9 \mathrm{~mm}$. by 5 , and has a somewhat different coloration, very similar to that of a third specimen, $11 \mathrm{~mm}$. by 6.75. In these individuals, the general color abactinally is greenish-white but this is largely obliterated by the development of the red blotches in both the ambulacra and interambulacra. These blotches are more or less coalesced so that the median twothirds of each interambulacrum and about half of each ambulacrum are quite reddish. The larger spines are greenish with red only at the base but the small spines are often tinged with red throughout.

The specimen $17 \mathrm{~mm}$. in diameter is $10 \mathrm{~mm}$. high and its coloration is much like that of the largest specimen but it is somewhat greener, the red shades are paler, the markings are less distinct and all the spines, even the actinal, have a reddish tinge.

The superb specimen from station 35 is $20 \mathrm{~mm}$. in diameter and $12 \mathrm{~mm}$. high; the abactinal system is not quite $6 \mathrm{~mm}$. across but the heavily plated peristome is 9 ; the primary spines are $4 \mathbf{- 5}$ $\mathrm{mm}$. long. There are 14 interambulacral and 15 ambulacral plates in each column. Ocular I is broadly insert but the other oculars are completely excluded from contact with the periproct. The test is greenish-white, nearly white abactinally, with large, squarish but irregular blotches of orange-brown or rusty-red at and above the ambitus. The shade varies according to moisture; it is brightest when wet. There are typically three blotches in each interambulacrum but the one at ambitus is low and imperfect. There are four in each ambulacrum but the one at ambitus is rather faint. In both series, the next to the lowest is largest and brightest. The periproctal plates are nearly white 
but the plates of the oculo-genital ring are variegated with greenish and reddish tints. Most of the abactinal tubercles are pale red. The actinal spines are nearly white but the bases of the larger ones and more or less of the entire length of small ones have a more or less marked greenish tinge. At and above the ambitus some of the spines become more or less pale red, the color being confined to the base of the spine or extending its whole length. The pedicellariae are white, as are the plates which cover the peristome.

The additional data which these Barbadian specimens furnish show that callipeplus is a very well marked species quite distinct from any other member of the genus. In its coloration, it is more like pictus and anamesus of the western coast of Mexico, or verruculatus of the Indo-Pacific region, than it is like its West Indian congeners but the shade of red shown by the tubercles, spines and abactinal spots is entirely different from anything exhibited by the other spotted species.

Station 7. May 16, 1918. W. by N. Pelican Island, 2 miles, 80 fms. Rocky bottom. Tangles. 1 specimen.

Station 11. May 17, 1918. 11/4 miles due west from white lighthouse at Needham Point, in line with red house, 6770 fins. Stony bottom. Dredge. 1 specimen.

Station 35. May 23, 1918. S. W. of Needham Point, 21/2 miles off shore, 80-90 fms. Rocky bottom. Tangles. 1 specimen.

Station 36. May 23, 1918. S. W. of Carlisle Bay, 2 miles off shore, 80-90 fms. Rocky bottom. Tangles. 2 specimens.

\section{LYTECHINUS EUERCES}

H. L. Clark, 1912. Mem. M. C. Z., 34, p. 247 ; pl. 107, figs. 4-6.

This typically West Indian sea-urchin is represented in the present collection by only a single specimen. It is $11 \mathrm{~mm}$. in diameter, with the abactinal system $31 / 2 \mathrm{~mm}$. across, and ocular I nearly or quite insert. A few of the actinal spines show traces of red. The periproctal plates are light apple-green, but elsewhere both test and spines are white or whitish. 
Station 6. May 15, 1918. North of Insane Asylum off spring garden or freshwater bathing place, 100 fms. Rough bottom. 1 specimen.

\section{LYTECHINUS VARIEGATUS}

Cidaris variegata Leske, 1778. Add. ad Klein, p. 85.

Lytechinus variegatus A. Agassiz, 1863. Bull. M. C. Z., 1, p. 24. Toxopneustes variegatus A. Agassiz, 1872. Rev. Ech., pt. 1, p. 298 ; pl. IVa, figs. 5 , 6.

In the Narrative of the expedition, Professor Nutting refers to the occurrence of this well-known species at several places in Antigua but does not speak of finding it at Barbados. Yet the only two specimens in the collection bear the label "Barbados". They are of about equal size ( $78 \mathrm{~mm}$. in diameter with primary spines 13-15 mm. long) but differ strikingly in color and were evidently selected as examples of the extremes in coloration. One has the test pale brownish-white with only traces of green; the tubefeet are very pale brown; the pedicellariae, muscles and small spines are whitish; the peristome, heavily plated, is pale brownish with traces of green; the primary spines are light green, whitish at base, dark at tip; many have one or two faint dusky bands elose to the tip; of many, the tips are regenerating. The other specimen has the test dull light green and whitish; the tubefeet are pale brown; the pedicellariae, muscles and miliary spines are white or whitish; the heavily plated peristome is dull greenish; the primary spines are deep, dark green, the tips becoming purplish but not markedly so; the secondary spines are pale yellow-green. In the Narrative (p. 189), Professor Nutting makes the interesting suggestion that the habit which both this species and Tripneustes esculentus have, of holding bits of sea-weed and other rubbish all over the dorsal surface, may be for the purpose of protection from the sun. It would be easy to ascertain whether this is the case and the habits of these sea-urchins would well repay careful investigation.

TRIPNEUSTES ESCULENTUS

Cidaris esculenta Leske, 1778. Add. ad Klein, p. XVII. Hipponoë esculenta. A. Agassiz, 1872. Rev. Ech., pt. 1, pp. 135, 301 ; pl. VI $a$, figs. $1-3$. 
Tripneustes esculentus Bell, 1879. Proc. Zool. Soc. London, p. 657.

In the Narrative, Professor Nutting refers often to this wellknown "sea-egg", one of the very few sea-urchins which have any economic importance. In some cases, the sea-egg is called Hipponö and in others, the correct name Tripneustes is used. Complaint is made ( $p .188$ ) that I have given no clue to the reason for abandoning Hipponoë, but this is hardly fair since I have given the full reference to Bell's paper where the matter was amply elucidated over forty years ago. It is no innovation of mine, to make use of Tripneustes. Hipponoë is preoccupied and there is no good reason for persisting in its use.

Professor Nutting calls attention (pp. 80, 188) to two interesting color forms of the sea-egg, and both are represented among the eight specimens in the present collection. The two forms seem to be reasonably distinct and further investigation of their differences and the causes thereof is worth while. Apparently in the pallid form the development of pigment is inhibited, only a little on the triphyllous pedicellariae being visible, while the peristome and gills are brown. In the melanistic form, pigment is markedly developed, especially on the peristome (particularly, close to the teeth), in the pedicellariae, in the tube-feet (except the white tips), in the tips of the branches of the gills and even to some extent in the epidermis of the test. The development of the pigment is not correlated with size but whether it is correlated with age is as yet unknown.

The specimens at hand range from $34 \mathrm{~mm}$. in diameter to 132 $\mathrm{mm}$. The primary spines on the smallest specimen are notably long $(9 \mathrm{~mm}$.), more than one-fourth the test-diameter. As a rule, they are hardly half as much as that.

Of the eight specimens, seven are from Barbados and one is from English Harbour, Antigua.

GENOCIDARIS MACULATA

A. Agassiz, 1869. Bull. M. C. Z., 1, p. 262. 1872, Rev. Ech., pl. VIII, figs. 1-18 (as Temnechinus maculatus).

Two bare, dead tests, without buccal membrane or periproctal plates, are the only representatives of this little sea-urchin in the 
collection. Both the "Hassler" and the "Blake" took Genocidaris off Barbados, but in each case three specimens taken together was the total capture, so it is obviously not common in that region. One of the bare tests of the present collection is 7 $\mathrm{mm}$, in diameter but the other is only 3.5.

Station 84. June 6, 1918. Spring Garden bears E. N. E., Needham Point Light, S. E. Off shore 11/2 miles, 100 fms. Fine, sandy bottom. Dredge. 2 specimens.

PSEUDOBOLETIA OCCIDENTALIS, sp. nov.

\section{Plate II, figs. 1 and 2}

Test $54 \mathrm{~mm}$. in diameter, $27 \mathrm{~mm}$. high, only a little concave orally and rather flat abactinally. Coronal plates 25 in each interambulacral column and 30 in the ambulacra; the interambulacra are about $19 \mathrm{~mm}$. wide at ambitus and the ambulacra about 14. Each interambulacral plate in the midzone has 4 large primary tubercles, the outermost is slightly the largest, the innermost is smallest; a large secondary tubercle occupies the outer end of the plate, encroaching on the ambulacra; there are 8-10 much smaller secondary tubercles, chiefly along upper margin of plate, and about a dozen irregularly scattered miliaries; orally the number of primary tubereles becomes reduced to 3 and then to 2 and on the lowest plate to one; the gill slits are very deep, reaching up between the tubercles of the third plate (from the peristome); aborally there are 4 primaries to the tenth plate (from the genital), 3 to the seventh and 2 to the fourth or fifth. Each ambulacral plate in the midzone has 2 primary tubercles and a secondary tubercle at each end; the outer secondary encroaches much on the poriferous area; it is wanting only on the lowest two plates and on the uppermost three or four; the inner secondary occurs only in the midzone; the inner primary occurs first on about the twelfth plate from the ocular. Pore-pairs in strongly curved ares of four, the lowest distinctly nearer the ambulacral mid-line than the uppermost.

Abactinal system small, only $9 \mathrm{~mm}$. across, the periproct only $4 \mathrm{~mm}$.; ocnlars I and $\mathrm{V}$ broadly insert, the others not nearly so; 
genital pores large near outer end of plate; ocular pores very small, about half way between center and distal margin; genital plates each with a large secondary tuberele, 3-6 large miliaries, and half a dozen or more minute miliaries; oculars with 3-6 large, and a number of minute miliaries. Periproct covered with about 20 plates, among which the suranal is scarcely distinguishable; the larger plates each carry 1-3 large miliaries.

Peristome large, about $22 \mathrm{~mm}$. across, with deep gill-slits; it is well plated but not heavily so; buceal plates large, nearly circular, the two of a pair close together, the pairs separated from each other by about a millimeter. Each buccal plate carries about half a dozen slightly club-shaped miliary spines, besides numerous small stout tridentate pedicellariae. Most of the nonambulacral plates of the peristome carry one or more miliary spines besides small stout tridentate pedicellariae.

Primary spines about $12 \mathrm{~mm}$. long at ambitus, terete basally and becoming flattened only slightly near tip; the tip itself is concave, not pointed; each spine has 20-22 well marked striations. Secondary and miliary spines, slender, cylindrical, bluntly pointed.

Pedicellariae numerous and diversified but only the small stout tridentate are at all common. In size and form the pedicellariae offer no characters by which they can certainly be distinguished from those of $P$. maculata. Globiferous pedicellariae rare, of two sizes, one with valves about $.80 \mathrm{~mm}$. in length, the other with valves about half as large. Ophicephalous pediccllariae rare, with valves about $.50 \mathrm{~mm}$. long and loops $.15 \mathrm{~mm}$. more. Tridentate pedicellariae in at least three forms: (a) slender, with valves, $1.25 \mathrm{~mm}$. long; (b) small stout, with valves about $.50 \mathrm{~mm}$. long; and (c) big, stout, with valves over a millimeter long, half a millimeter wide and very serrate margins; only one of these big pedicellariae was noted. Triphyllous pedicellariae with valves $.22 \mathrm{~mm}$. long and about $.18 \mathrm{~mm}$. wide near tip.

Color (in alcohol) pale brown with a distinctly greenish east, the midzone with about 20 large irregular blotches of a distinctly darker shade; there are two of these blotches in each ambulacrum and interambulacrum but they vary in size and distinctness. Primary spines pale fawn-color, decidedly greenish basally and very faintly pinkish at tips; on the dark blotehes 
the primaries are deep brownish-green, light only at the tips, but there is much diversity in the relative proportions of green and pale fawn-color.

Holotype labelled only "Barbados", but Professor Nutting tells me that "in all probability it came from a depth of between 30 and 100 fms."

The discovery of Pseudoboletia in the West Indian region is certainly one of the most noteworthy results of the Barbados. Antigua Expedition, for the genus is not known on the western coast of tropical America and is really characteristic of the Indo-Pacific fauna. On June 10, 1904, the "Scotia" took two specimens of a Pseudoboletia in $40 \mathrm{fms}$. off the island of Ascension, in mid-Atlantic but well south of the equator. It is remarkable that the new species from Barbados is not very close to this Atlantic species, ${ }^{1}$ which has five pairs of pores to an are and banded actinal spines, but is so very close to $P$. maculata of the Philippines that one hesitates to call them distinct. The following differences however warrant keeping them separate, at least until more material is available. In maculata, the inner primary tubercle of the ambulacra appears first on the seventh, eighth or ninth plate from the ocular, in specimens $52-55 \mathrm{~mm}$. in diameter, while in occidentalis it occurs first on the tenth-twelfth plate; this is not an important character and will probably prove inconstant and unreliable. In maculata the periproct is covered by about 30 plates and the oculo-genital ring is more granulated, than in occidentalis. The primary spines of the midzone in maculata are markedly flattened, with bluntly chisel-shaped tips (though with a terminal concavity), and are 14-16 $\mathrm{mm}$. long. Their color too, green at base and red-purple or reddish at tip, is quite different from the pale colors of occidentalis.

In view of the insignificance of these differences, the question naturally arises whether the Barbados specimen was not accidentally brought from the East Indian region (or possibly from Hawaii). Professor Nutting assures me there is no doubt whatever that the specimen at hand was collected at Barbados. It is not ineonceivable that a small specimen of maculata might have been brought on a very foul ship bottom through the Panama

\footnotetext{
${ }^{1}$ Kohler called the specimens from Ascension $P$. maculata but they really represent quite a different species, which I have proposed (1912, Mem. C. Z., 34, p. 344) to call atlantica.
} 
Canal to Barbados, but that seems so highly improbable that we are better justified in believing that Pseudoboletia is a natural member of the Barbadian fauna. It is strange that neither the "Blake", the "Hassler", nor the "Albatross", nor any other collector in the West Indies, has met with the genus but the reason may be that the vessels mentioned did nearly all their collecting outside the $100 \mathrm{fms}$. line while the other collectors have done very little dredging at any depth. The teeming area between 10 and $100 \mathrm{fms}$. has scarcely been touched as yet.

ECHINOMETRA LUCUNTER

Echinus lucunter Linné, 1758. Sys. Nat. ed. 10, p. 665.

Echinometra subangularis A. Agassiz, 1872. Rev. Ech., p. 283, pl. Xa, figs. 2-4.

Echinometra lucunter Lovén, 1887. Ech. Linnaeus, p. 157.

Of this very common species, there are 94 specimens in the collection, of which 7 are bleached bare tests. Only three are from Barbados, the remaining 91 being from the Pillars of Hercules and English Harbour, Antigua. The largest specimen is $53 \mathrm{~mm}$. long, $43 \mathrm{~mm}$. wide and $28 \mathrm{~mm}$. high, while the smallest is about $9 \times 8 \times 4.5$. Some of the specimens from English Harbour are very dark-colored, a very dark purple-drab or a violet-black. They are also quite wide in proportion to the length and look as though the ambitus were a circle, but examination shows the width is always $1.5-3 \mathrm{~mm}$. less than the length. The Barbados specimens are of two types of coloration: 2 are fawn-color becoming purplish-red at spine tips, while the third is dark olive, the primaries with purple tips.

At English Harbour, specimens taken from the rocks near the entrance show the effects of the heavy surf in which they spend so much of their lives. The primary spines are nearly all distorted or regenerating at the tip. In the Narrative (p. 189), Professor Nutting describes the conditions under which the Echinometras flourish at Antigua. In speaking of their occurrence at Barbados (p. 83) he says that $E$. viridis is a "very common form" and that $E$. lucunter is "less common". As there are no specimens of viridis in the collection and both Barbados 
and Antigua are well outside its known range, I think dark greenish specimens of lucunter have been mistaken for viridis.

\section{CLYPEASTER ROSACEUS}

Echinus rosaceus Linné, 1758. Syst. Nat. ed. 10, p. 665.

Clypeaster rosaceus Lamarek, 1801. Syst. Anim. s. Vert., p. 349.

Echinanthus rosaceus A. Agassiz, 1872. Rev. Ech., p. 311; pl. XId, figs. 1, 2.

The only evidence of the occurrence of this well known species in the region visited by the Iowa party, is a group of fragments of a bare test about $80 \mathrm{~mm}$. long, taken at English Harbour, Antigua.

MELLITA SEXIESPERFORATA

Echinodiscus sexiesperforata Leske, 1778. Add. ad Klein, p. 135.

Mellita sexiesperforata Meissuer, 1904. Bronn's Thierreichs, 2, abb. 3, buch 4, p. 1384 .

There are three fine specimens of this well-known "key-hole urchin" from Barbados. Their color in alcohol is bright yellowbrown. While one specimen is longer than wide, $78 \times 76 \mathrm{~mm}$., the other two are distinctly wider than long, $80 \times 82 \mathrm{~mm}$. and $66 \times 69 \mathrm{~mm}$. The labels do not indicate just where or under what conditions these urchins were taken, and there is no mention of them in the "Narrative".

\section{ECHINOEUS CYCLOSTOMUS}

Leske, 1778. Add. ad Klein, p. 109.

This well-known cosmopolitan echinoid has taken on new interest recently from the fact that it is now fairly well demonstrated that it is a Holectypoid, the genus Echinonëus and its near relative Micropetalon being the only living representatives of that order (See Hawkins, 1920, Phil. Trans. Roy. Soe. (B), 209, p. 442). Both at Barbados and Antigua, Echinonëus was found in its eustomary habitat, in the sand beneath rock fragments. There are 3 specimens in the collection from Barbados 
and 33 (of which 18 are bleached, bare tests) from English Harbour, Antigua. The smallest specimen is $7 \mathrm{~mm}$. long by $5 \mathrm{~mm}$. wide; the largest is $35 \times 29 \mathrm{~mm}$. The form of the test shows much diversity, the width ranging from .66 to .77 of the length and the height from .39 to .48 .

AGASSIZIA EXCENTRICA

A. Agassiz, 1869. Bull. M. C. Z., 1, p. 276. 1883, Mem. M. C. Z., 10, pl. XXV.

Twice during the dredging off Barbados, the bare dead tests of this species were met with. All are small, ranging from 5.5 to $9.5 \mathrm{~mm}$. in length; the largest is $8.5 \mathrm{~mm}$. wide and $8 \mathrm{~mm}$. high.

Station 48. May 27, 1918. S. W. of Lazaretto, W. by N. of Pelican Island, 25-72 fms. Coarse coral sand. Dredge. 3 specimens.

Station 77. June 3, 1918. Cable station bears $31 / 2$ S. 1 mile off shore. 40-50 fms. Dead bottom-coarse sand. 2 specimens.

\section{BRISSUS BRISSUS}

Spatangus brissus (var. unicolor) Leske, 1778. Add. ad Klein, pp. $\mathrm{xx}, 182$.

Brissus brissus H. L. Clark, 1917. Mem. M. C. Z., 46, p. 218.

This spatangoid, almost always found associated with Echinonëus, was not taken at Barbados, although it is recorded from that island and probably occurs there. From Antigua there are 48 specimens, of which 4 are bare tests. One was taken at the Pillars of Hercules but all the others are from English Harbour. The smallest specimen is $22 \mathrm{~mm}$. long, $17 \mathrm{~mm}$. wide and $11 \mathrm{~mm}$. high, while the largest is $61 \times 45 \times 36 \mathrm{~mm}$. One specimen is peculiarly deformed, as a result of a serious injury at some time in interambulacrum 4, which is now entirely healed; this specimen measures $42 \times 35 \times 25 \mathrm{~mm}$. In the Narrative (pp. 190-192), Professor Nutting discusses in a very interesting way the peculiar subsurface habits of Brissus and Echinonëus. My own observations of these species agree well with those of the Iowa 
party, but I have not noted that the depth below the surface was as great as six inches. In many cases the animals are just below the surface. As a rule the larger the animal the more deeply it is buried. Probably the animals move up and down in the sand with changes in temperature and tidal conditions, and no doubt the larger individuals move more rapidly and greater distances than the smaller ones. The food is certainly in large part diatoms and other unicellular organisms.

Museum of Comparative Zoölogy

Cambridge, Mass.

May 28, 1920 


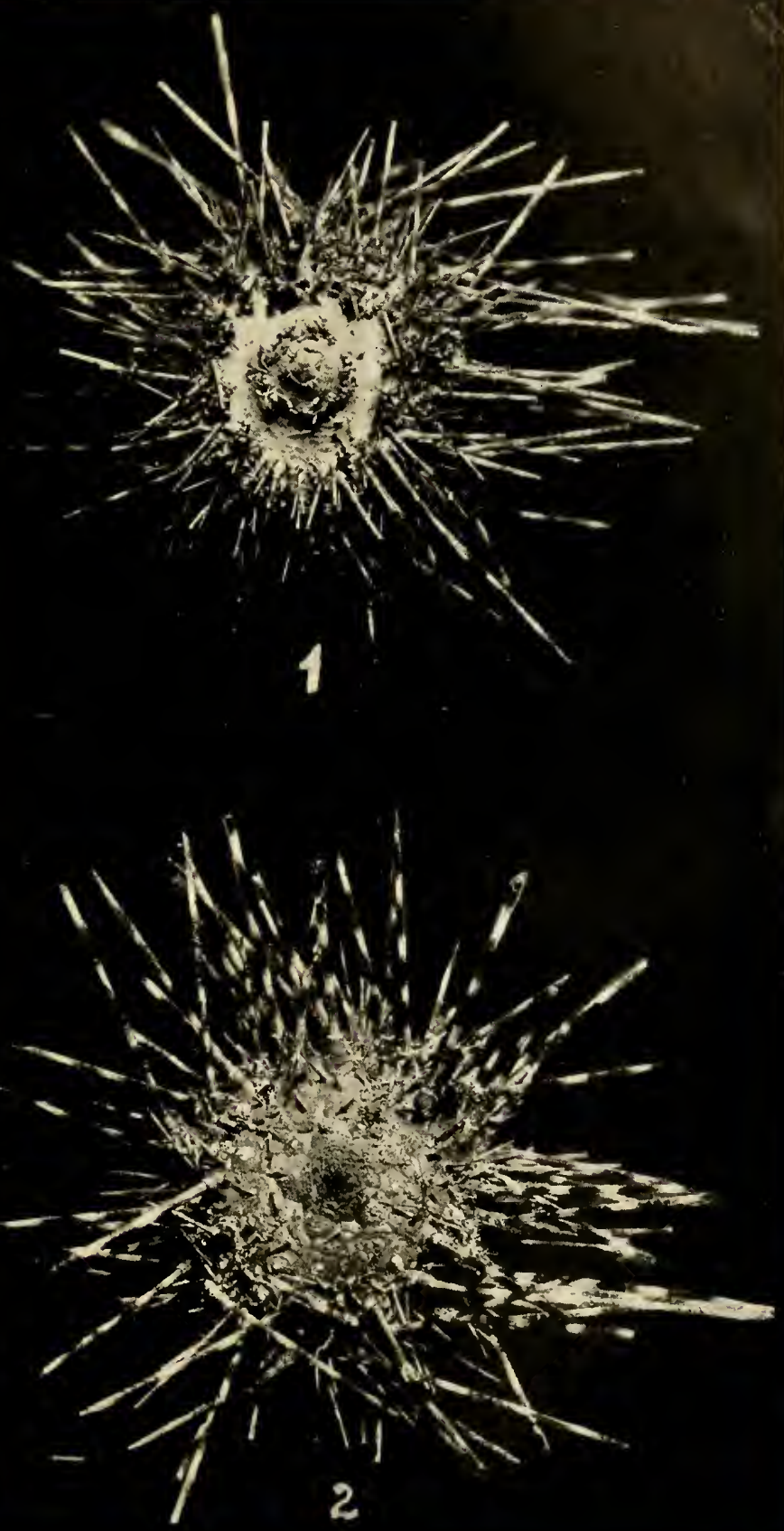

Centrostephanus rubicingulus. $\times 3$.

1. Oral view. 2. Aboral view. 



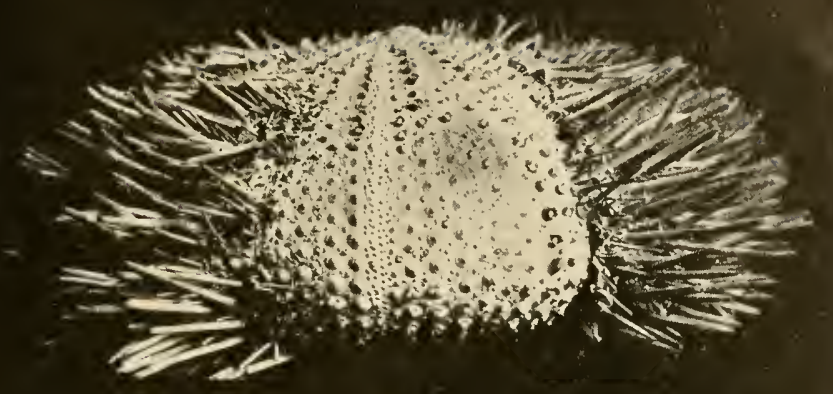

1

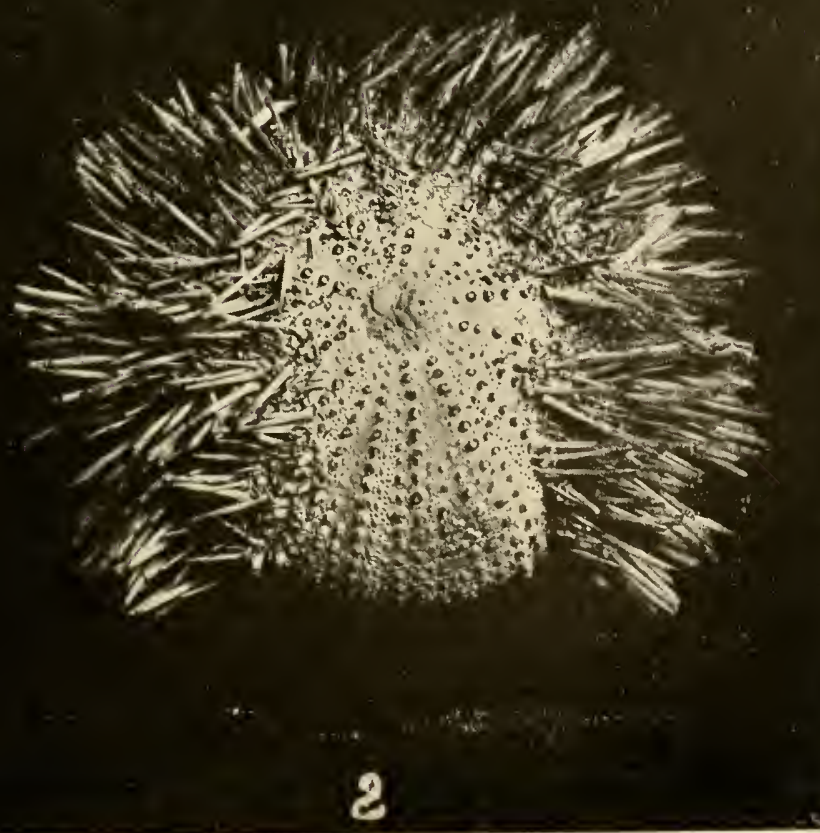

Psendoboletia oecidentalis. Nat. size.

1. Sicle riew. ‥ Aboral riew. 



SMTHSONIAN INSTTUTION LIBRAAIES

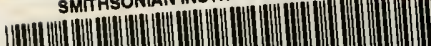

m. m. (m.

39088010905511

Obtainable from the University

Librarian; $\quad$ Price, $\$ 1.50$ 